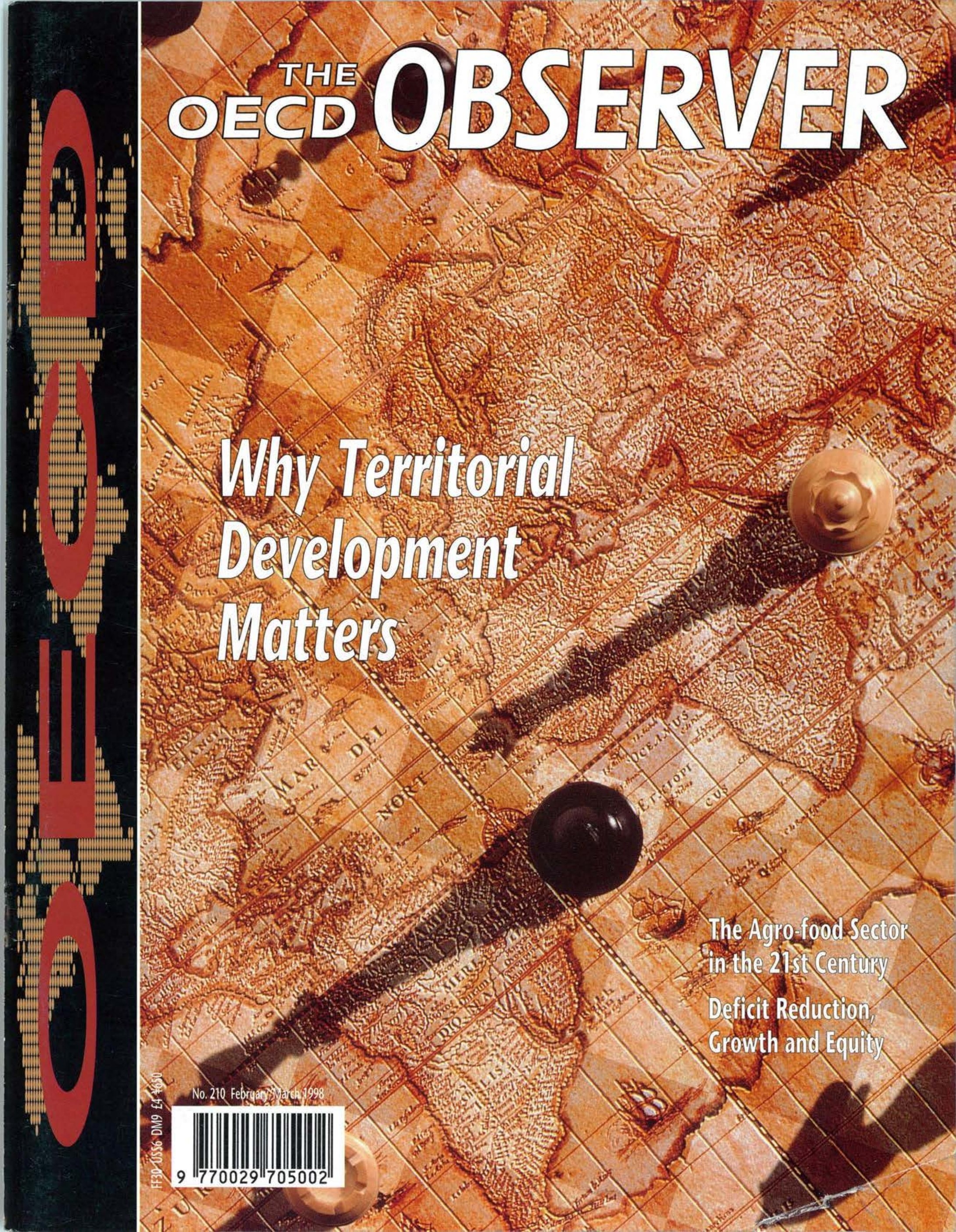




\section{Regional Competitiveness and Skills}

Human resources, training, qualifications and skills play an essential part in the development of regional economies. The notion of 'learning' regions which has now become selfevident has yet to be translated into practice: but under which conditions and what are the priorities? This publication gives a comprehensive picture of current practices and future issues. Regional policies are increasingly focusing on human resources and their orientation towards market demand and improvement of partnerships. The diversity of regional approaches to human resource development in industrialised countries shows that an efficient regional governance, coupled with concern for equity, can reinforce and consolidate national policies. This volume casts a new light on these issues, providing a useful source of information and inspiration for regional actors and their national partners.

December 1997

FF220 US\$36 DM65 £22 ¥4,250

(0497041) ISBN 926415684-4

\section{TERRITORIAL DEVELOPMENT}

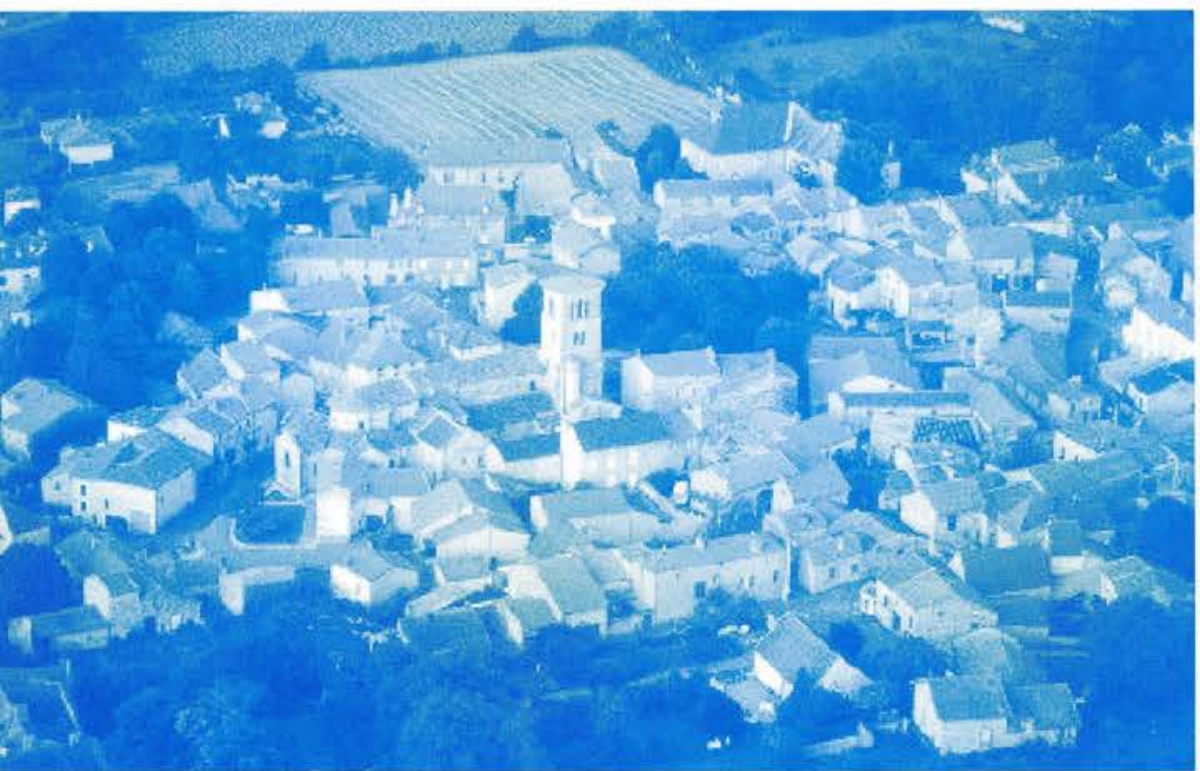

Partnership in the United States

Increasing globalisation requires more rural development than ever before. The concept of partnership is a particularly effective instrument in this respect, making it easier to harmonise and co-ordinate central and grassroots policy approaches. The United States provides an illuminating example. Development programmes used to be designed and implemented independently by various Federal ministries, but the introduction of different forms of partnership over the last few years has shifted the focus towards a more global approach to rural development. This publication examines the mechanisms for establishing and running successful partnerships. Although each country has its own traditions and a specific administrative culture, this review offers a number of general lessons for co-ordinating horizontal policies, both at central and sub-national level.

April 1997

FF125 US\$25 DM $37 £ 16 ¥ 2,650$

(0497021) ISBN 926415467-1

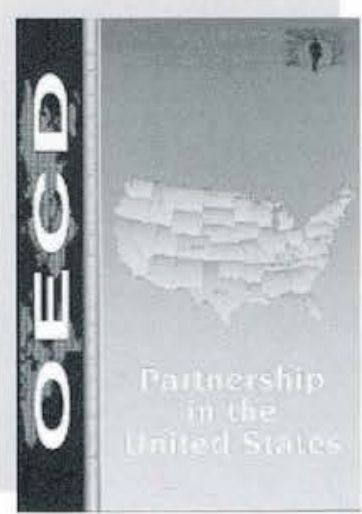

Regional Development and Structural Policy in Mexico

Mexico is a multi-faceted country. Given the geographical and ethnic diversity of Mexico's regions, as well as their particular cultural and historical traditions, each of the regions making up the Federation calls for a specific development policy. At the same time, economic, political and social equilibria are going to be affected by the trend towards more decentralisation of political structures. Mexico is faced with two major challenges. How can consistency of government action be maintained in conjunction with a firm resolve to decentralise? How is it possible to reconcile regional and national development while striving to achieve the country's integration within the world economy? This study, which includes many tables, maps and figures, makes it possible to define these challenges more clearly and therefore to clarify regional policy options for the coming decade.

December 1997

FF155 US\$26 DM46 £16 ¥3,000 (0497051) ISBN $926415687-9$

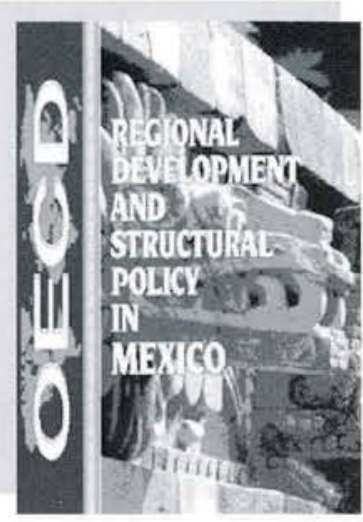

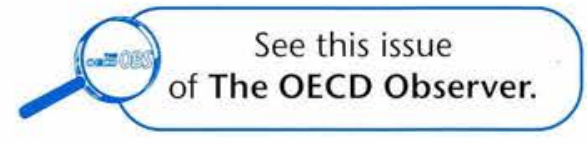

Better Understanding Our Cities

The Role of Urban Indicators

Urban indicators are essential for understanding changing social, economic and environmental conditions in cities. Policies, economic instruments, regulations, behaviour and lifestyles can adapt more easily to these changes when citizens, firms and governments have access to relevant urban indicators. This report surveys the 'state of the art' in designing and using urban indicators, and calls attention to specific types of indicators - in particular cross-sectoral that should be developed. But it is not easy to find indicators that are simple to use. International co-operation is essential to achieve a

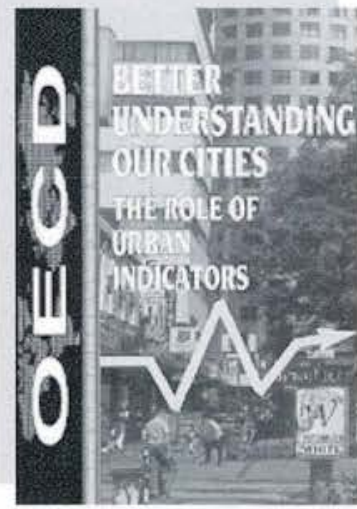
common standardised set of indicators.

April 1997

FF120 US\$24 DM35 £15 ¥2,550

(0497011) ISBN 926415454-X

Entrepreneurship and SMEs in Transition Economies The Visegrad Conference

September 1997

FF140 US\$28 DM40 $f 18 ¥ 2,950$ (1497071) ISBN 926415611-9

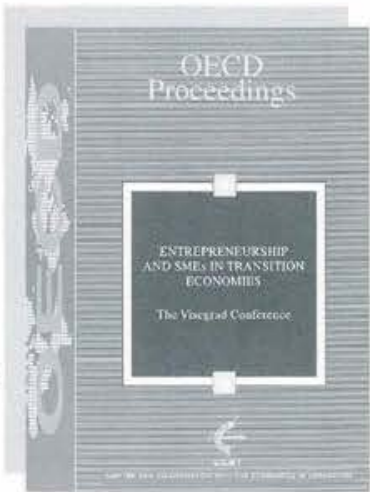




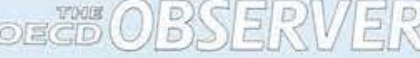

Published every two months in English and French by the ORGANISATION FOR ECONOMIC CO-OPERATION AND DEVELOPMENT

\section{Editorial Address:}

OECD Publications

Château de la Muette

2 rue André-Pascal

F 75775 PARIS CEDEX 16

Tel. $+33(0) 145 \mathbf{2 4} \mathbf{8 2 0 0}$

Fax $+33(0) 145241815$

E-mail: obs.mag@oecd.org

Web: http://www.oecd.org

O OECD 1998

Applications for permission to reproduce

or translate all or parts of articles from

The OECD Observer.

should be addressed to:

Head of OECD Publications,

2 rue André-Pascal,

75775 PARIS CEDEX 16, FRANCF

Reprinted and translated articles should carry the credit line Reprinted from the

OECD Observer plus date of issue. Signed articles reprinted must bear the author's

name. Two voucher copies should be sent to the Editor,

Signed articles express the opinions of the authors and do not necessarily represent the opinion of the OECD.

All correspondance should be addressed to the Editor.

The Organisation cannot be responsible

for returning unsolicited manuscripts.

Editor

Ulla Ranhall-Revners

Associate Editor

Martin Anderson

Assistants

Catherine Nalle

Carol Thornton

Design

Codicom/Bonté Divine!

Layout

Frédérique Bidaux

Catherine Nallet

Carol Thornton

Photo Research

Silvia Thompson

\section{Sales}

Single copies:

FF30 - US\$6 - DM9 - $\$ 4$ - $¥ 650$

Annual Subscription Rates:

FF150 - US\$30 - DM 46 - $\$ 17-¥ 3,200$

Tel. $+33(0) 149104269$

$\mathrm{Fax}+33(0) 149104276$

E-mail: sales@oecd.org

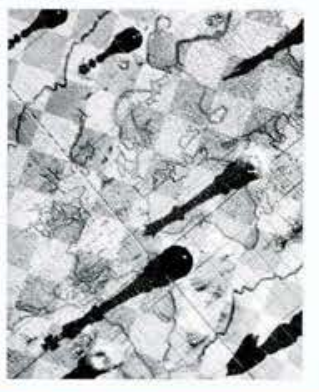

Globalisation is moving more and more of the

February/March 1998

traditional levers of policy - economic, social.

institutional and legal - beyond the reach of

government. That same trend links the wealth

of nations more closely with their territorial

development - with the competitiveness of their

regions, with the strengths and weaknesses of

local economies.

C. Anabella Breakey/Fotogram-Slone

\section{Editorial}

Territorial

Development

Why Territorial Development Matters

Donald J. Johnston

$$
\text { Analysis }
$$

Territorial
Development

The Insights of Territorial Indicators

Heino von Meyer

Arresting Decline in Urban Areas

8

Andrew Davies

New Business in Rural Areas

Chantal Illouz-Winicki and Denis Paillard

Regional Policy in Mexico

Denis Besnainou and Laurent Davezies

Entrepreneurship in the Russian Federation

20

Paul Paradis and Almorò Rubin de Cervin

\begin{tabular}{lll}
\hline Innovation & Patents, Innovation and Globalisation & 23
\end{tabular}

Georges Ferné

Agriculture

The Agro-Food Sector in the 21st Century

28

Reza Lahidji

Reconciling Agriculture and the Environment

32

Wilfrid Legg and Michel Potier

\begin{tabular}{cl}
\hline Economy & $\begin{array}{l}\text { Fiscal Consolidation, Growth and Equity } \\
\text { Robert Ford }\end{array}$ \\
Spotlight & 37 \\
\hline
\end{tabular}

Economy

Portugal - The Health System

42

Marcos Bonturi

The Russian Federation - Commercial Banking

45

John Litwack

Observer Exclusive

Economy

Indicators

48

For the Record

\begin{tabular}{ll} 
Economy & The OECD Economic Outlook: Highlights \\
\hline Industry & The OECD Industry Committee at Ministerial Level
\end{tabular}

$$
\text { Bookstore }
$$

Just Published New OECD Publications

Where to Obtain OECD Publications 


\section{Why Territorial \\ Development Matters}

Donald J. Johnston, Secretary-General of the OECD

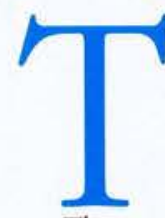

he 'new global age' presents OECD countries with many economic, social and political challenges. Expanding world markets, faster technological progress and near-instant communications are accelerating the pace of change throughout society.

These global trends affect us all but require businesses and governments to adjust their strategies to the specific context of their societies so as to generate the right action on the ground. Hence urban and rural policy, and local and regional policy what we at the OECD have called territorial development - have attracted increased attention as the injunction to think globally and act locally' has taken hold.

The attention being paid to territorial development policies reflects a recognition that regions and localities must be dynamic and flexible to reach their potential. Central government policies can be reinforced by measures at the grass roots to stimulate entrepreneurship and innovation.

Territorial policies, historically concerned with the equitable geographical distribution of resources, should now focus more on mobilising local resources to build competitive strength and create jobs. This change in emphasis can add impetus to the restructuring of national economies by reinforcing the capacity for self-generated change.

The economic policies agreed by OECD Ministers involve sound macro-economic policies to ensure stable prices and healthy government finances, and structural policies to improve the efficiency of markets and raise living standards. Translating such policies from the national level to the regional or local level will be more successful if territorial authorities introduce complementary measures.

Complementarity among macro-economic, structural and territorial polices is important for several reasons:

- structural economic changes depend for maximum success on stimulation of regional and local entrepreneurship and innovation - central government policies rely on dynamic communities in which business, public authorities and civic society can establish new partnerships and follow approaches adapted to their circumstances

- dynamic communities can strengthen social cohesion by, for example, facilitating 'welfare to work' policies to integrate the unemployed and excluded, and by pioneering new forms of democratic participation.

Territorial development policies are a practical, operational means of contributing to the balance between economic growth, social stability and good governance that I have advanced as a framework for OECD action.

At their 1997 meeting, OECD Ministers agreed that the challenge today for governments is to 'pursue policies whereby the benefits of globalisation are fully realised and widely shared by all groups of society'. Territorial development policies can make an important contribution to meeting this challenge in the years ahead. 


\section{The Insights of Territorial Indicators}

Heino von Meyer

The OECD countries all face a number of challenging issues: employment, productivity and income, migration, urbanisation, aging populations, pollution, bio-diversity, and many others. Yet the effects are not spread evenly inside national borders. Territorial indicators, based on sub-national, regional and local statistics, can reveal the diversity of conditions and trends inside and among countries in far more detail than aggregated national statistics. They can supply important information about untapped development potential and can signal newly emerging economic, social or environmental issues which traditional forms of analysis can identify only with long delays.

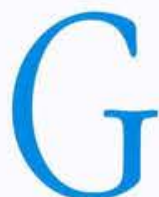

lobalisation increases the relative importance of sub-national regional economies in policy analysis, design and implementation. The wealth of nations is ever more closely linked to the competitiveness of their regions, and the strengths and weaknesses of their local economies.

Indeed, globalisation is putting beyond the reach of national government more and more of the economic, social, institutional and legal parameters that were once under its control. National barriers to competition and all sorts of regulation are being progressively dismantled and removed. Essential price relations, like exchange rates or interest rates, are less and less suscept- ible to manipulation by central administrations. By loosening national ties and enforcing international competition, globalisation confronts subnational regions both with development opportunities and with threats not previously known. On balance, globalisation is expected to bring gains to economies in their totality, but it will nonetheless pose severe problems of adjustment to a good number of regional economies.

The reaction to structural change and the pressures of adjustment can sometimes produce difficult policy decisions, since politics is often based on conventional wisdom, on fears and false assumptions rather than on fact. And without accurate data and adequate indicators that are territorially differentiated, informed decisions will be difficult to take, in all tiers of government.

\section{A New Dimension}

Socio-economic development analyses deal with three dimensions: thematic, temporal and territorial. The first two are familiar. Over the centuries economics has developed sophisticated tools for modelling and assessing the role of time in a vast range of themes. The dynamics of growth and cyclical fluctuation, for example, or of structural change and adjustment are conceptualised in a wide number of ways. Yet only limited attention has been paid to the territorial dimension. Economic interactions and transactions are analysed, among individual persons or firms, or among countries, but those are usually treated as single entities ('point economies'), not as complex territorial systems of interrelated units and lavers. It is customary (if unrealistic) to assume perfect mobility of factors, goods and services; at best, transport and other communication costs are taken into account. If structures or structural changes are assessed, conventional analyses tend to focus on the sectoral mix by branches, on demographic patterns by age or gender, on types of enterprise or social cluster; only exceptionally do they extend to territorial structures, such as urban centres and rural areas, leading or lagging regions, thriving or distressed local communities.

For a long time the work of the OECD was likewise concentrated on time series for various themes, while more detailed territorial analyses were rare. The Organisation is accorded a high

Heino von Meyer works on statistics and indicators in the Rural and Regional Development Division of the OECD Territorial Development Service.

E-mail: territory.contactBoecd.org 


\section{The Insights of Territorial Indicators}

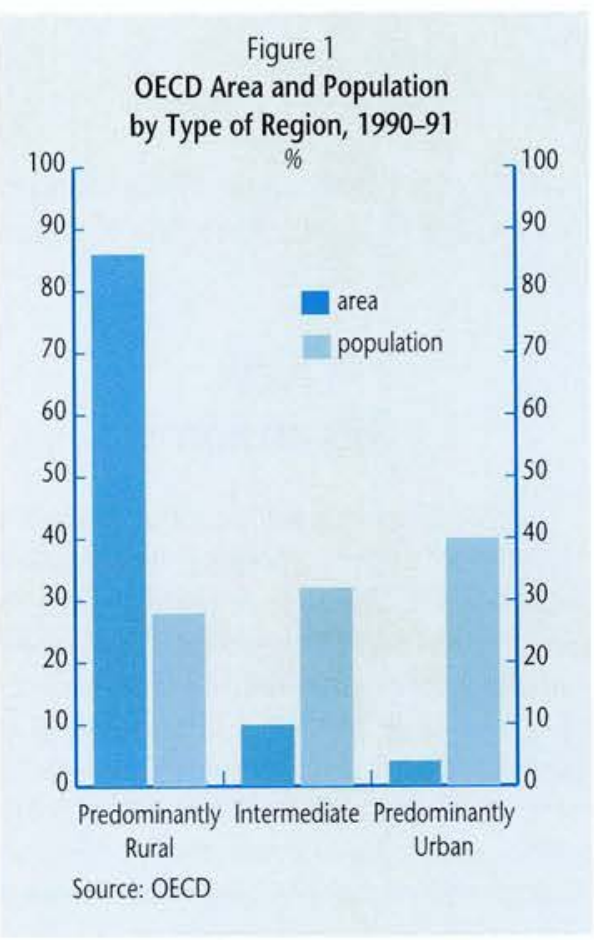

degree of respect for the quality of its statistics, which are both detailed thematically and in time. Yet until recently the third dimension, territory or space, remained underdeveloped. The OECD's Territorial Development Service (TDS), created in 1994 to bring together formerly dispersed programmes on local development, urban affairs, rural development and regional policy, has meanwhile embarked on the task of establishing an internationally consistent territorial data base, covering more than 2,500 sub-national regional units across OECD countries.

As OECD statistics prove, territorial differences, diversity and disparities matter. And this is true not only among nations but also within countries. Neglecting sub-national development problems and potentials can cause major inefficiencies, and costly socio-economic repercussions, even to the point of causing political unrest in disadvantaged regions. Yet there is another, equally relevant, reason for generating and analysing sub-national territorial data: inno-

1. Territorial Indicators of Employment - Focusing on Rural Development, OECD Publications, Paris, 1996. vation and rapid change can make even the most accurate time-series analysis irrelevant, since they change the context. Pressing issues are often not yet well covered by data sets, and there can be substantial delays before time-series are long enough to allow 'robust' analytical results - by which time it may be too late to take effective action.

Instead, development issues can be analysed by comparing sets of territories, regions or cities, in different stages of development. This can be done with data for only a single year, or by comparing two points in time, provided that the set covers a large enough number of territorial units. In this way, statistics can generate warning signals for emerging concerns. Take (for example) biodiversity loss: on national indicator lists plant and animal species may not yet appear as threatened' - although the trend towards extinction has already been observed in several regions. In many parts of the country, 'endangered' species may have already become extinct before the phenomenon becomes visible on a national scale. By focusing on the specific conditions of the regions where decline was first observed, one might have been able to discern - much more quickly and cheaply - the main reasons for the reduction in biodiversity.

The set of territorial data and indicators being built up by the OECD is thus intended to highlight the importance of sub-national territorial diversity in development conditions and trends. The scheme covers the entire surface of the OECD countries, it distinguishes local and regional layers, and it classifies territories according to analytical requirements, as rural or urban, leading or lagging, and so on. A basic set of demographic, economic, social and environmental indicators has been selected, and the first series of data have been collected, processed and published.'

\section{The Advantages of Disaggregation}

A simple disaggregation can demonstrate the importance of territorial analy- sis (Figure 1). Currently, some $40 \%$ of the total OECD population live in highly urbanised regions, which cover only $4 \%$ of the OECD territory. At the other extreme, a quarter of the population lives in predominantly rural regions that cover $86 \%$ of the surface area. The remaining third of the population lives on $10 \%$ of the territory. The economic and social conditions in which these different groups are living are in many respects very distinct. Some struggle with problems of over-agglomeration while others suffer from peripherality. Availability of resources and access to services and infrastructures are fundamentally different. So efficient solutions for generating and sustaining economic development are unlikely to be the same across the board. Technologies and organisational patterns that may be perfectly well adapted to highdensity areas will not be suitable in places where population density is much lower.

The OECD approach aims to provide a consistent and flexible framework for undertaking various kinds of differentiated territorial analyses. It allows, for example, the analysis and clarification of apparently contradictory observations. Territorial patterns of population change in Germany over the 1980s offer an illustration (Figure 2). In that decade the total population increased by $1.7 \%$. Yet in rural

Figure 2

Population Change in Germany, 1980-90

$\%$
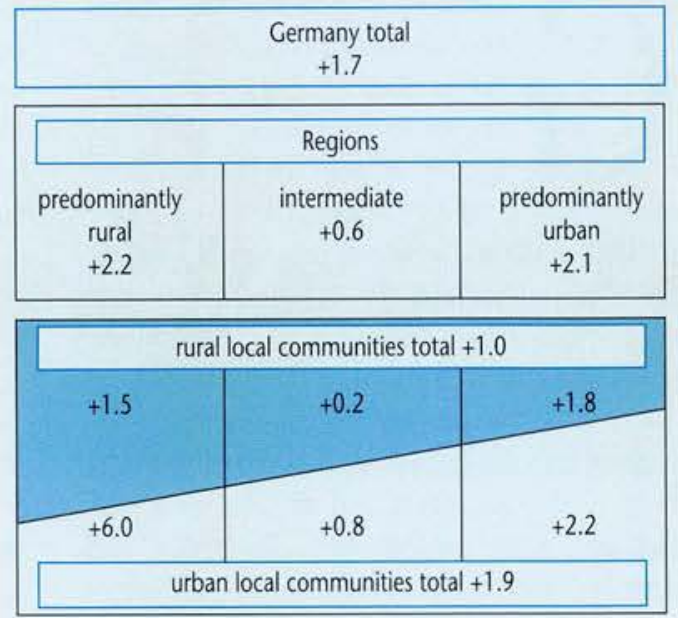
communities (local units with a population density below 150 inhabitants per $\mathrm{km}^{2}$ ) the increase was only half that in urban communities: $1.0 \%$, compared with $1.9 \%$. From a more aggregated, regional viewpoint, the predominantly rural regions (those where more than $50 \%$ of the population live in rural communities) showed the biggest increase $(2.2 \%)$. Here, indeed, population growth was even slightly higher than in urbanised regions $(2.1 \%)$, while the figure for intermediate regions stagnated $(0.6 \%)$

Thus, depending on the choice of aggregation for analysis, one can come to very different conclusions. Figure 2 underlines the importance of differing local dynamics within each type of region. In the predominantly rural regions, small and medium-sized towns experienced by far the highest increase $(6.0 \%)$. Among the rural (local) communities, those in urbanised regions gained most (1.8\%). In intermediate regions both rural and urban communities showed only modest increases. This approach clearly demonstrates that rural and urban development issues can no longer be treated separately. Urban centres have a critical role to play in the economic development of rural regions, while important environmental or recreational qualities of urban regions depend, in fact, on those of their remaining rural areas.

Demographic structures, such as age-cohorts or gender, can also provide territorial indicators with an economic relevance. Geographical concentrations of young and old populations are important considerations in assessing the viability of local infrastructures and services. The location of these populations will condition the effectiveness of different solutions for providing education, health care, and so on; and the costs per unit of delivery might be very different.

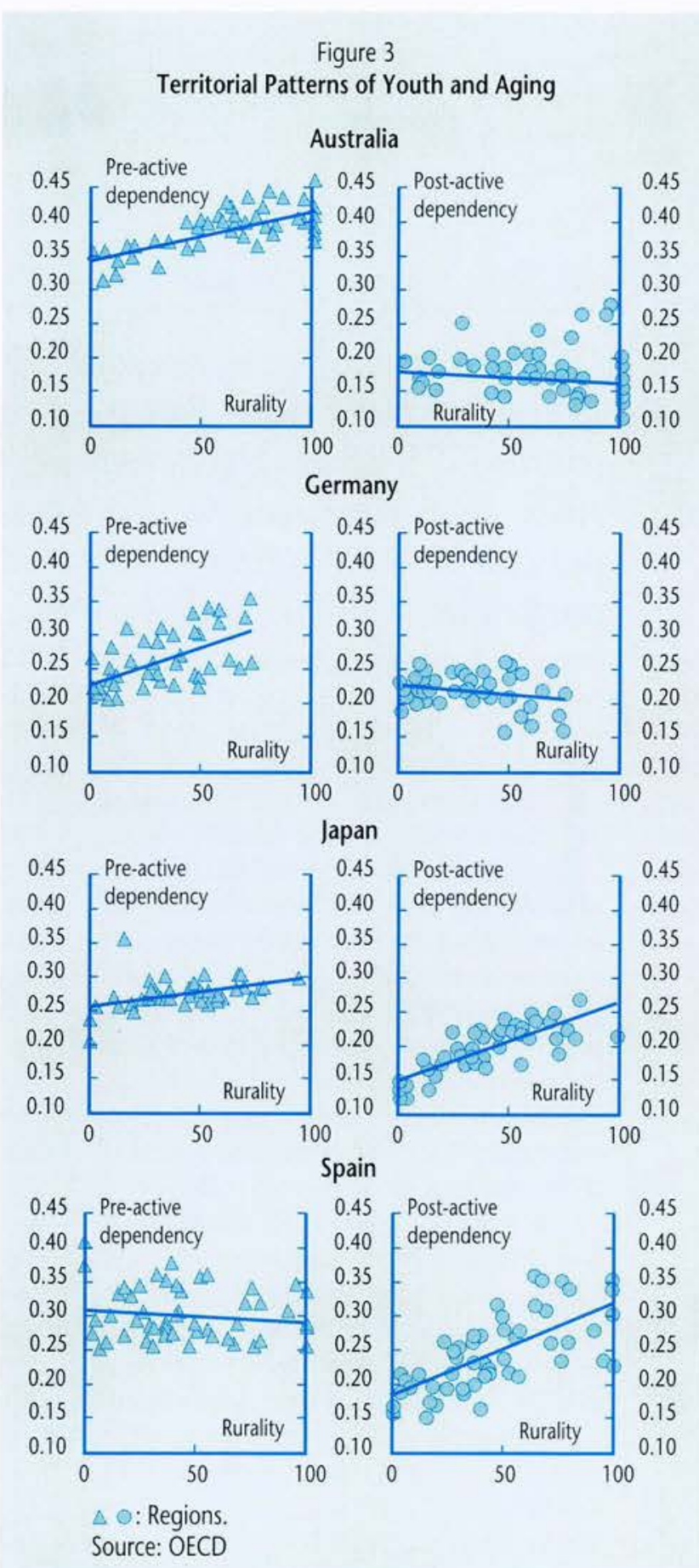

structure. If dependency ratios are compared across subnational units, a clear pattern can be observed. In all OECD countries ratios are positively correlated with rurality. Rural regions always have higher percentages of dependent populations. The higher the regional percentage of rural population (living in local communities with densities below 150 inhabitants per $\mathrm{km}^{2}$ ), the higher the regional share of young and old people.

Obviously, this characteristic will have repercussions for the regional economy and might suggest a higher concentration of support policies. But the impact will be different if instead a region depends on young or aged populations. Some retirement regions usually in places with high amenity values - have even completely specialised in providing services to older populations, whose pension income can bring considerable wealth to the local economy.

Figure 3 demonstrates that the territorial patterns of age-structure within and among OECD countries are rather different. Correlations with the degree of rurality, or urbanisation, are sometimes positive, sometimes negative. Although in Germany and Australia, say, the share of aged populations is often higher in urban than in rural regions, for Japan and Spain the opposite is true. In these two countries there is a strong positive correlation between rurality and aged populations.

Thus, in most OECD countries, population aging has a clear territorial dimension. Analyses and policies that address such issues in the future should take territorial implications explicitly into account. Social transfers and pensions, the provision of social infrastructure and services will all affect regional

Dependency ratios - a coefficient of the number of young (aged below 15) and old (65 and above) inhabitants to those aged 15-64 are commonly used to assess differences in ageeconomies. And it is vital that relative demand in urban and rural regions for schools and healthcare facilities be known. It is not only a question of numbers of clients: the appropriate 
technologies and organisational structures for efficient public and private service delivery will not be the same in urban and rural regions.

\section{1}

The importance of territorial patterns in demographic and other social phenomena is becoming clear. But territory matters also for the assessment of economic structure and performance. For instance, as work on the territorial patterns of employment has shown, urban regions have often been more successful than rural regions in creating new jobs. But a distinction between leading and lagging regions shows that more people live in declining urban regions than in badly-off rural ones. And, in the event, many rural regions have been able to generate higher rates of employment growth than the national economy, again pointing to the unsatisfactory nature of sweeping statements based on national aggregates. Urbanised settlement patterns are in no way a guarantee for better economic performance; and rural regions are not doomed to decline. Indeed, if the causes of rural or urban successes were better understood, it might become possible to stimulate employment in both rural or urban areas that are still lagging. -

\section{OECD BIBLIOGRAPHY}

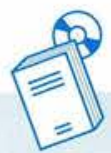

Networks of Enterprises and Local Development, 1997

Sergio Arzeni and Jean-Pierre Pellegrin, 'Entrepreneurship and Local Development', The OECD Observer, NN. 204, February/March 1997

Territorial Indicators of Employment - Focusing on Rural Development, 1996

Heino von Meyer and Philippe Muheim, 'Employment is a Teritorial lssue', The OECD Observer, №. 203, December 1996//anuary 1997

Creating Rural Indicators for Shaping Territorial Policies, 1994.

\section{Arresting in Urban}

Andrew Davies

\section{Distressed urban areas are found wherever in inner cities and} in suburbs the normal process of revitalisation has failed. Left untreated, such areas generate substantial social and economic costs. To compensate for the limited effectiveness of sectoral policies in responding to the concentration of problems in particular districts, governments are innovating with areabased, integrative strategies.

I n the period immediately after the Second World War, much of South Central Los Angeles was a prosperous, vibrant, high-employment, mixed-race, mixedincome area. Sharp neighbourhood decline began in the 1970s as the manufacturing sector contracted, leading to factory closures and relocations and to high unemployment, followed by a movement out of the area, initially of white residents and later of middle-class black residents. The result was a rapid undermining of the economic and social fabric of the area, a spiral of decline that took just a few years to develop.

This example is typical of the two-stage process of neighbourhood change that has transformed previously stable working-class areas of many OECD cities. The first phase, from stability to transition, is characterised by an increase in unemployment. The closure of a local factory, for example, or the decline of the dominant local industry, brings about a reduction in real incomes, caused partly by unemployment but also by initial out-migration by wealthier residents. Although in some instances the local

Andrew Davies works in the Urban Affairs Division of the OECD Territorial Development Service.

E-mail: territory.contact(Boecd,org economy can emerge from recession or new economic activities develop, some areas decline to what has been called a state of 'structural crisis'. When this stage is reached, poverty and unemployment are accompanied by a lowering in educational attainment, reduced rates of family formation, the burgeoning of an informal economy, and increased criminal activity. By this time, the area has usually acquired an unfavourable reputation which serves to reinforce exclusion and inhibits potential rejuvenation through inward investment.

The starting point of this transformation and its consequences are difficult to clarify, but the main catalysts are clearly economic - a fall in real incomes, reductions in participation rates, increased benefit dependence, and so on. But other 'exogenous' factors also play an important role. For example, changes in government policy, such as more stringent zoning regulations, which restrict the availability and location of affordable housing and reduce the quality of public services and of mass transport infrastructures, can radically reduce the attractiveness of a local area as a residential location. When local individuals and institutions - not least home-owners, businessmen, would-be entrepreneurs, insurers, bankers and civil servants - perceive that such a process is taking 


\section{Decline}

\section{Areas}

place, they react to protect investments and minimise risk; and many choose to move.

As wealthier residents and enterprises filter out of an area, the concentration of groups vulnerable to poverty increases. The main categories concerned include single-parent families, families with young children, people with low or no formal educational qualifications, ethnic/ racial minorities, recent immigrants and those in sheltered housing, such as the disabled. The concentration of these groups can become striking. In comparison with a typical urban area, the deprived areas in the United Kingdom, for example, have $20 \%$ more residents under 15 years of age, 35\% more under 25 years, $15 \%$ more with long-term disabilities, and twice the number of lone-parent families. Roughly the same general pattern - of a local population significantly different from the national norms - can be discerned in France (Figure, p. 11) and in numerous other $\mathrm{OECD}$ countries.

Disadvantaged areas in OECD countries share a wide range of other characteristics: very low educational attainment, low in-school performance at all ages and high rates of delinquency, high long-term youth unemployment, high crime rates, low degrees of participation in community associations, low turn-out in elections, high proportion of households with no car and/or telephone, high permanent disability/invalidity rate, high incidence of preventable diseases such as tuberculosis.

Concentrated deprivation also leads to a form of discrimination based on place of residence, often termed 'address effects', which means that employers are reluctant to hire people who live in particular areas; potential entrepreneurs are unable to get commercial loans for start-ups; and young people in the area have problems finding places in higher education.
The decline of a city-centre can be rapid - Los Angeles, soon after the Second World War, was rich and multi-ethnic, offered a wide range of jobs, and was inhabited by a broad mix of social groupings.

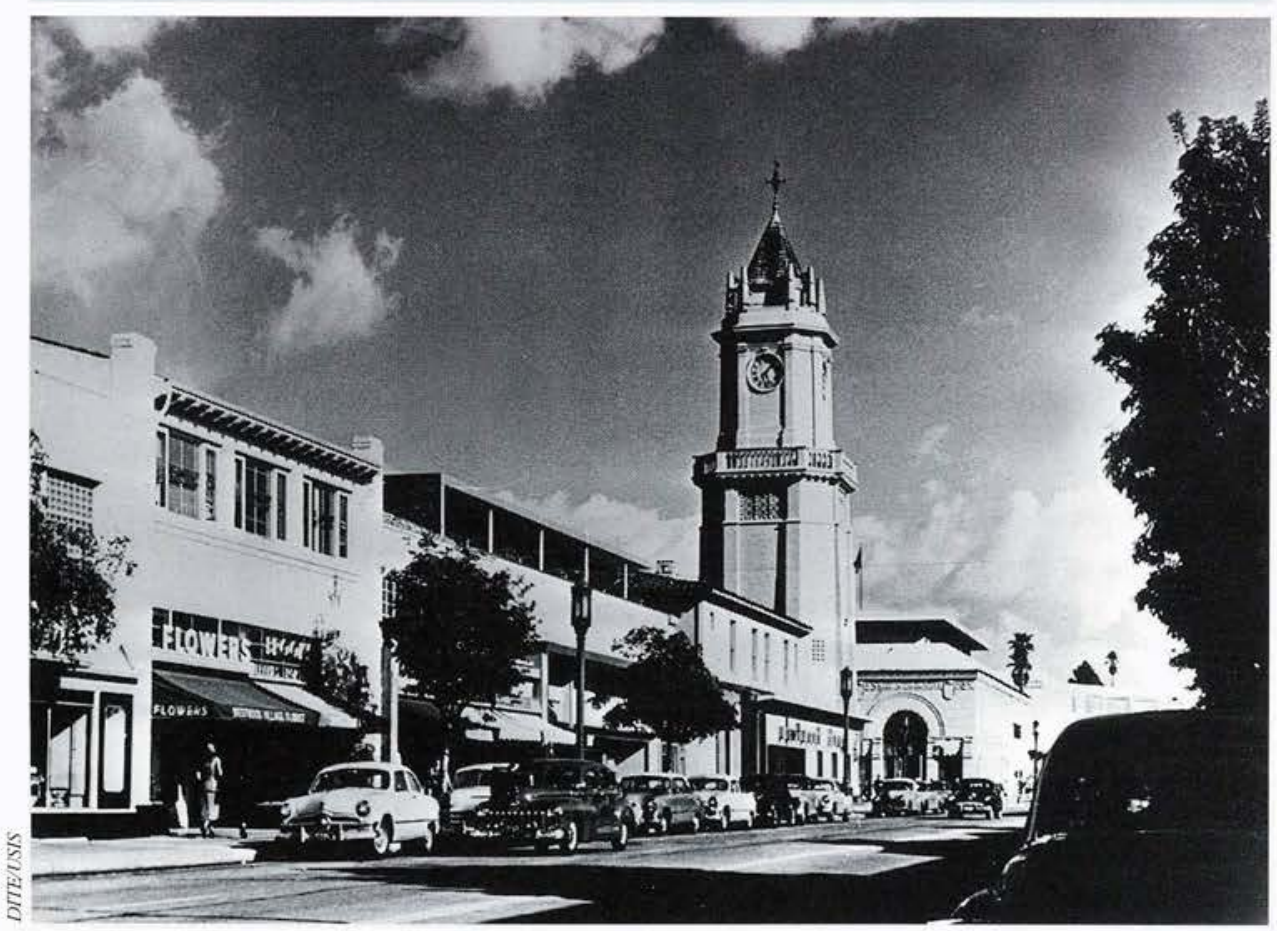

Each of these phenomena involves at some stage a loss of individual potential, a reduction in personal choice and opportunity and implies extra expenditure by government. Moreover, prevalence of one characteristic produces prevalence of another, and these mutually reinforcing relationships combine to generate a vicious cycle of decline. Left alone, the condition of these areas tends to worsen systematically, even to spill over into adjacent areas. Breaking the cycle and arresting decline require substantial additional policy effort but would avoid even larger socio-economic costs and fiscal expenditures in the future.

\section{Tackling Concentrated Deprivation}

Multiple deprivation of this type has a number of important repercussions:

- local residents have difficulty obtaining educational or vocational qualifications as a result of poorer educational facilities and fewer role models

- low-skilled workers tend to be isolated from jobs when enterprises move elsewhere

- 'negative externalities', such as high crime rates and vandalism, inhibit the creation of local employment opportunities by, for example, requiring firms to install expensive security equipment or paying inflated insurance premia - because of low rents (or high vacancy rates in public housing), these areas tend to house the least well-equipped migrants - from other parts of the city, other cities, rural areas, or other countries

- the dominance of the informal economy means that much entrepreneurial activity is undeclared.

Policy measures intended to rejuvenate these areas thus should take into account the complex mix of factors involved. Low employability, for example, is caused by lack of skills, but also by prejudice against people from particular neighbourhoods; and degraded physical environment is caused by poor design and maintenance, but also influenced by behaviour patterns that undermine concepts of common ownership and local pride. 


\section{Arresting Decline in Urban Areas}

\section{FOCUS}

\section{Two Integrated Urban Policy Approaches}

\section{The Area-Based Approach \\ to Long-Term Unemployment in Ireland}

At the core of Ireland's effort to reduce the incidence of concentrated unemployment are 38 Area-Based Partnerships in disadvantaged urban and rural communities created by the Irish Government and the Structural Fund of the European Union (EU) in 1991. The task of these partnerships is to reconsider the problems of unemployment within their jurisdictions and devise effective responses to them. Legally the partnerships are independent corporations under Irish company law. Their boards group representatives of local community interests, including the unemployed, representatives of the national organisations of labour and business, and local or regional representatives of the national welfare, training or economic-development administrations. Through this structure, the partnerships often have de facto authority over a substantial share of the local activities and expenditures of core agencies of the national government. In addition, they have the right to provide services and build institutions not contemplated by the statutory bodies.

In six years of operation, urban partnerships have developed innovative techniques for retraining and placing the long-term unemployed and building potentially self-sustaining firms that provide both training and jobs for them. They have also established new programmes to help young people leaving school early and single mothers, and to encourage community policing and the management of housing estates by their tenants. These innovations, moreover, are accompanied by local proposals for adjustments to the rules governing eligibility for social welfare benefits whose purpose is to make participation in the new programmes broadly affordable and attractive, and to remove the disincentives that often deter the most needy from exploring their possibilities.

\section{The SRB Challenge Fund \\ in the United Kingdom}

City Challenge, launched in 1991, and its successor, the Single Regeneration Budget Challenge Fund introduced in 1994, were major departures from previous, centrally defined urban policies for a number of reasons:

- the Single Regeneration Budget (SRB) combines funds from four government departments under one roof, with the aim of simplifying administration and providing more flexibility in the use of funds, and is administered by deconcentrated regional offices

- the programme is based on the assumption that strategy should be defined locally rather than nationally, with government establishing overall guidelines

- applications for funding must come from formal partnerships that include the community sector, who must be involved in the development of strategic plans and participate in implementation - an explicit recognition of the importance of the 'bottom-up' approach - bids could include a wide range of activities, such as enhancing the employment prospects, education and skills of local people; improving the competitiveness of the local economy; improving the physical environment and housing and housing conditions; promoting initiatives of benefit to ethnic minorities; tackling crime; and raising the capacity of community groups - partnerships were expected to leverage private-sector finance of at least double the public-sector commitment

- the allocation of funds was organised as a 'competition' with local partnerships making formal bids and central government choosing the most promising applications.

The range of possible projects that can be funded by partnerships was intentionally broad in order to encompass the range of local requirements and responses - defined locally. In fact, it has been argued that the objectives are less important in the long term than the process by which these objectives are achieved. In other words, the process of consultation and partnership involving a range of different groups and associations, including representatives from the community sector, is a more significant institutional development than the simple number of jobs created. The task of working together to formulate and implement a strategy strengthened these partnerships, engendering a spirit of co-operation and trust that had not been present in the local setting before.
Government initiatives in OECD countries over the past twenty years have approached the question from a number of different angles: - additional resources have been allocated to specific areas and their residents (positive discrimination) or additional benefits and entitlements made available to individuals wherever they reside

- funding has been provided for services and programmes used only by particular groups, such as job clubs and other employability schemes for the long-term unemployed and day-care centres for single mothers, or general amenities available to all residents, such as libraries or public parks

- programmes have promoted mobility and/or commuting by local residents able to relocate or improvement of employment opportunities and housing conditions in the local area

- inward investment by enterprises from outside the area has been encouraged through subsidies and incentives or concentration on building endogenous economic development capacities through training and entrepreneurship programmes

- wholesale area clearance and redevelopment or incremental renovation and modernisation.

In general, centrally conceived and administered sectoral programmes to limit urban deprivation have been only partially effective in $\mathrm{OECD}$ countries. First, sectoral policies, chiefly welfare and housing, were unable to cope with the changes in population profiles and socio-economic conditions that were affecting many urban areas. Second, few policies were introduced in a strategic, co-ordinated manner appropriate to the interrelated problems that characterise distressed areas.

One approach that was politically popular in the 1980 s was the promotion of mobility, encouraging people to move to where opportunities were more plentiful by subsidising homeownership, particularly for first-time buyers, and through the construction of affordable housing units in suburban areas. But because these policies were implemented without a clear area-wide strategy, and did not take enough account of the ability and inclination of people to relocate, they have had only limited success. As a result, 


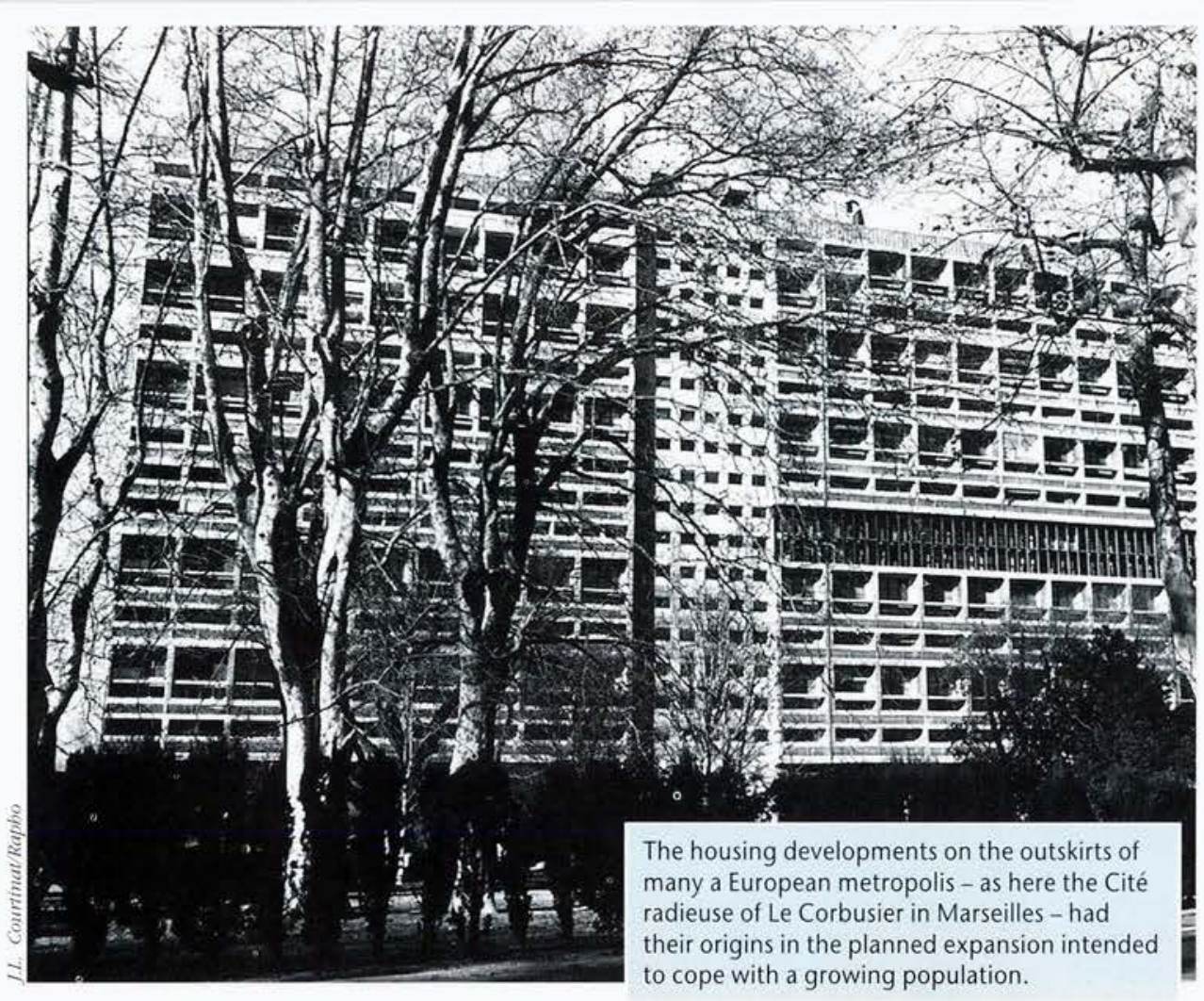

these programmes have often benefited only the better-off local residents who were able to afford the part of relocation costs not taken on by the government. Perversely, the net effect was to increase the concentration of low-income families in the deprived area. Such policies have also encountered strong opposition from residents of other neighbourhoods within the metropolitan area who fear that in-migration of lower-income families will affect the prices of houses. In some countries, moreover, construction companies have not been keen to provide low-cost housing in middle-class developments. Furthermore, the implication that residents should try to 'escape' from certain neighbourhoods has stigmatised the area concerned, again impeding its regeneration.

\section{Integrated Development}

In spite of these setbacks, the process of trial and error in urban policy in OECD countries over the past two decades has led to the emergence of more integrated, multi-sectoral policy approaches which have two main characteristics: they explicitly recognise the inter-relationships between the socio-economic factors affecting urban areas; they stress endogenous development and the creation of opportunities within the deprived neighbourhood.

One fundamental assumption of this new policy approach is that the first task of central government is to ensure that framework conditions favour balanced urban growth and regeneration of run-down areas. Government should thus guarantee the full range of services and functions that are provided elsewhere. In some cases this step involves providing extra resources to compensate for the additional costs, often incurred by the local authority, of providing basic infrastructures. In addition, government should recognise that in some areas private markets do not provide equal access - for example, to venture capital or financing, which is particularly difficult to obtain for entrepreneurs from distressed areas. Other means to this end are the relaxation of land-use regulations (on the basis of an overall urban-region development plan) and the re-allocation of infrastructure spending to guide growth to particular areas. In addition, government has a crucial role to play in limiting the pernicious effects of racial prejudice in the labour and housing markets, and working to reduce social segregation.

A second assumption is that central government alone cannot address the complex problems facing distressed areas; instead of over-ambitious direct action, it can better provide the institutional framework by which a concerted, partnership-based policy can be delivered. A number of common features can be discerned in current strategies of OECD governments to foster integrated policy responses: - a dynamic approach to social policy by means of a more flexible, co-ordinated delivery of mainstream policy involving, for instance, the establishment of inter-ministerial commissions to assure national coherence

- an emphasis on targeting funds to specific local areas and the development of systems by which national goals can be achieved on the basis of locally devised strategies
- the involvement of non-governmental institutions from the private, community and associative sectors in strategic planning, policy formulation and implementation in local frameworks

- the promotion of formal and informal institutions based on partnership between a number of different bodies

- clearer monitoring and evaluation of policy effectiveness, including the recognition of local initiatives as sources of innovation and ideas to inform national policy

Over the past decade, a number of programmes have been introduced by OECD governments that incorporate these characteristics. such as the Major Cities Programme in the Netherlands, the Zones dinitiative privilégiées, Contrats de quartier and Social Impulse Fund in Belgium, the US Empowerment Agenda, including the Empowerment Zones and Enterprise Communities programme, the range of measures included in the French Politique de la ville (Contrats de ville, Pacte de relance pour la ville, Zones franches urbaines, and others), City Challenge and the Single Regeneration Budget in the United Kingdom and the Irish Anti-Poverty Strategy and numerous initiatives in the framework of the

\section{Figure \\ France: Population Characteristics in Distressed Urban Areas, 1991 \\ $\%$}

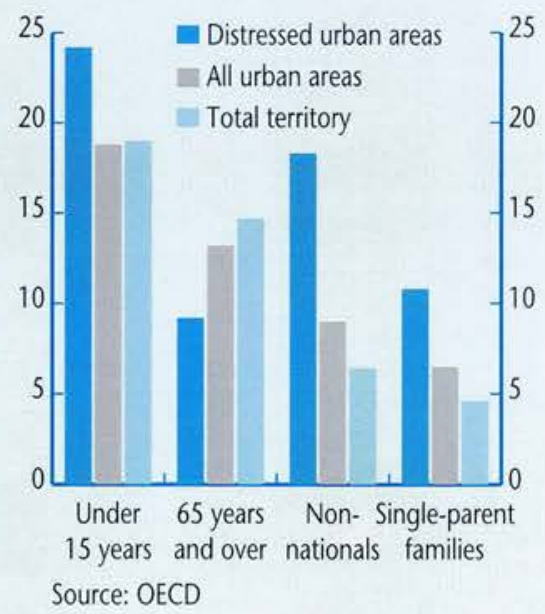

The OECD OBSERVER No. 210 Februany Marcb 1998 
Operational Programme for Local, Urban and Rural Development (box, p. 10).

\section{-}

The process of developing integrated strategies is relatively advanced in some countries and at the planning stage in others. In those with a longer history of national urban policy, a clearly observable process of incremental improvement in policy design can be seen. Indeed, current policies are the result of conscious adaptation of previous measures, now enhanced by the extensive exchange of information between countries. The debate there is moving on to issues such as: the implementation of preventative as well as remedial strategies; the development of effective spatial targeting and resource-allocation models for identifying the areas involved; the institutionalisation of processes for community empowerment; the provision of flexible funding channels for local initiatives; the setting up of monitoring and evaluation procedures that encourage 'policy learning' and better exchange of ideas.

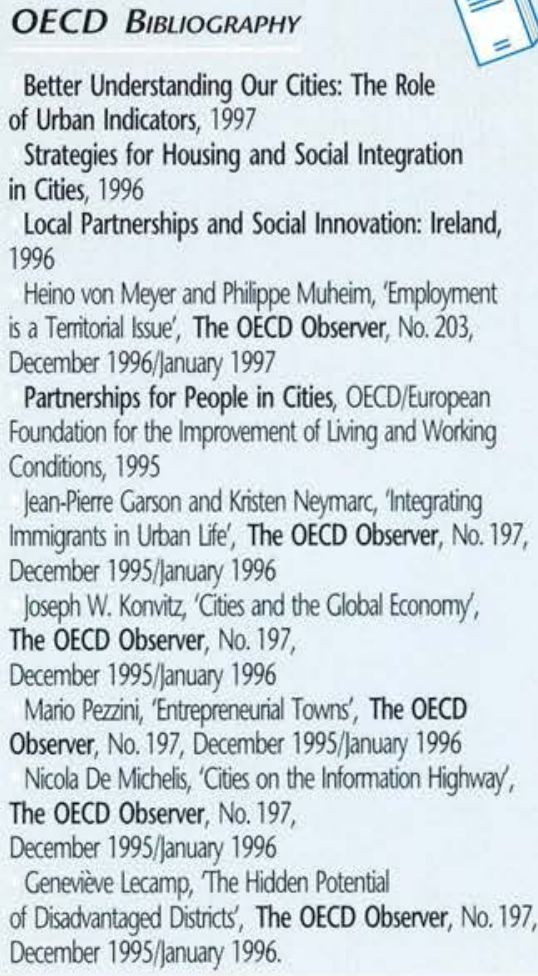

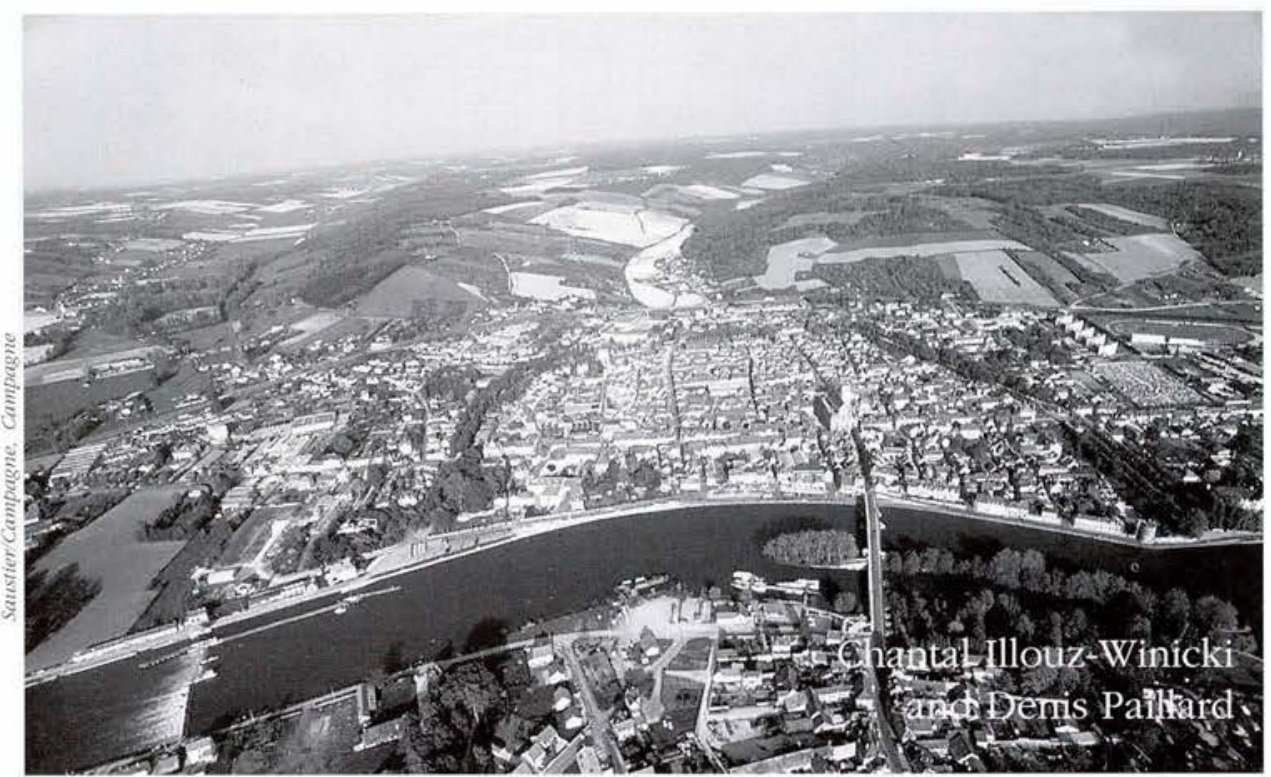

Rural areas are changing. Employment is rising, and more and more urban 'migrants' are settling there. How can the dynamic factors crucial to a country's growth be fostered? And how can the special features of rural areas be put to full use, and these dynamic factors encouraged in areas in difficulty?

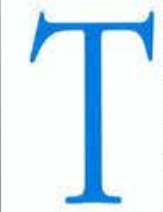
wo features have been shared by a good number of rural areas in $\mathrm{OECD}$ countries over the past ten years or so: a marked rise in employment, and population increase above the national average. But the disparities between rural areas are nonetheless becoming more marked.

The 'intermediate regions' - where more than half of the population live in communities of less than 150 inhabitants per $\mathrm{km}^{2}$ - show the best results: in 21 of the 25 countries examined the rise in employment is above the national average, by as much as 9.5 percentage points in Canada and 7.3 points in the United Kingdom. They account for $42 \%$ of net job-creation across the OECD countries, in other words, as much as all urban areas, and are the only regions to show a net gain in industrial employment.

Employment growth in the predominantly rural regions - defined as those where the population is spread between sparsely inhabited communities and small and middle-sized towns - is, taken as a whole, below the OECD average. But

Chantal Illouz-Winicki and Denis Paillard work in the OECD Territorial Development Service. Denis Paillard also lectures at the Institut national polytechnique in Toulouse (INP-ENSAT).

E-mail: territory.contact@oecd.org in most member countries a few of them are among the most dynamic areas, particularly in Germany (Lower Bavaria) and the United Kingdom (the Western Isles). A rural area is therefore not necessarily a backward area (Figure).

It is not easy to explain why an area is dynamic, or backward. Complex forces are at work: specific local factors, structures and aspects that are hard to assess precisely, such as cultural traditions, business networks and an attractive natural setting.

Over the last ten years new development trajectories that are specific to rural areas have become apparent. They rely on local 'networks', where firms offset their lack of size through coordinated operations (for example, the clusters of firms operating in Northern and Central Italy). Small and medium-sized towns, where a substantial share of industrial production is concentrated, play a key role. ${ }^{2}$ In these towns and to

1. Mario Pezzini, 'Entrepreneurial Touns', The OECD Observer No. 197, December 1995/January 1996.

2. Heino won Mever and Philippe Mubeim. Employment is a Territorial Issue; The OECD Observer, No. 203, December 1996January 1997.

3.D. Keeble, The Influence of the Rural Milieu on Enterprise Creation, OECD-TDS, working document, forthcoming 1998 :

4. Undertaken for France Initiative Réseaux, this survey looks at differences between urban and rural enterprises in particular at their ability to obtain financing. 


\section{New Business}

in Rural Areas

some extent around them, services are the main source of job-creation; calling for little capital, services also represent the bulk of businesscreation. Away from the towns, agriculture remains important, but more in terms of landuse and -management than for employment and business-creation.

\section{Special Characteristics}

Broadly speaking, rural areas have three special features for business-creation. First, growth in rural economies comes more from existing enterprises than new ones, particularly in the industrial sector. As a rule, there is less 'turbulence' (creation and destruction of firms) than in urban areas. New businesses are accordingly less common than in cities and larger towns, but survival rates are better: in France, between 1987 and 1995, the five-year survival rate fell gradually as population density increased, from $51 \%$ (communities with under 5,000 inhabitants) to $44 \%$ in towns. A number of reasons can be advanced: higher continuation rates (firms set up to take over existing activities), less competition in local markets, more determination when firms run into difficulties, through a genuine or perceived lack of alternatives, meaning that less money is taken out of the firm or more capital injected.

Micro-firms (those with under ten people on the payroll) and self-employment predominate in business-creation in rural areas. Research in the United Kingdom indicates that 'migrants' from towns play a central role here. ${ }^{3}$ These are skilled people who settle in rural areas and bring their technical knowledge and business connections with them. Their choice of location is governed as much by reasons of 'quality of life' as strictly economic ones, or more so, which places the value of some incentives (tax relief, grants and so on) in a different light.

A SOFRES survey $y^{4}$ underway in France confirms the importance of personal considerations in decisions to locate in rural areas: closeness to home $(36 \%)$ and other personal reasons (28\%) predominate, followed by opportunity $(24 \%)$. Strictly economic reasons come after that: closeness to markets $(16 \%)$, financial savings $(8 \%)$, local infrastructure (4\%), closeness to suppliers (3\%). Specific area assistance receives little mention: only $1 \%$ of locations.

Last, business-creation in rural areas covers a varied range of activities - crafts, commerce and services - and the multiplier effects are slight for those aimed at the local market (which is narrow) but larger for those directed at outside markets, generating trade and financial flows. In isolated areas, business-creation is usually aimed at local consumer markets (retailing, community services) or new market niches (products with a strong regional identity). In more accessible areas it is aimed more at services or intermediate goods

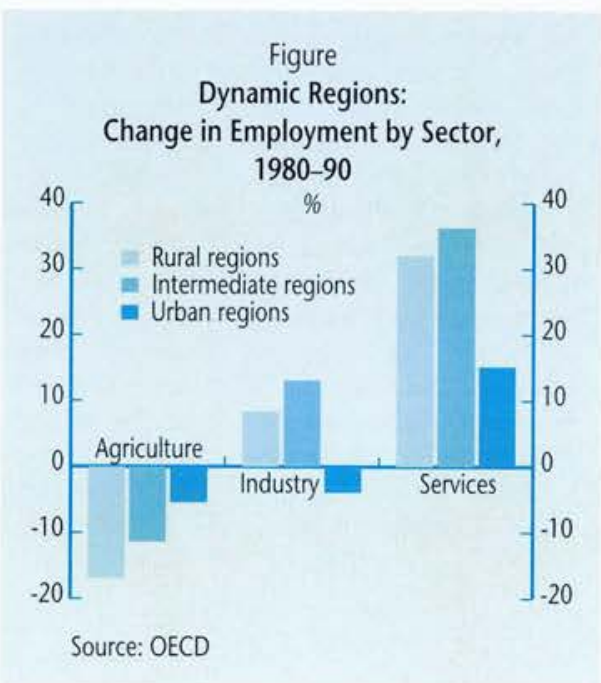

(sub-contracting). It is notable that business services, from office maintenance to consulting, are still under-represented in rural areas because local markets are so small.

In short, business-creation in rural areas is hampered by inaccessibility, the lack of communications infrastructures and business services, and a shortage of human resources. But decisions to set up in business and to locate in a particular place often seem to be based on personal considerations, and these constraints only come into the equation later on. The structure of the economic environment (its fabric, and networks of small firms) and the input from migrants, on the other hand, both seem decisive factors in the creation of new businesses, as the example of industrial districts confirms.

\section{New Market Niches}

As economic globalisation proceeds, heightened competition in generic items is leading to specialist production in areas where it is appropriate, and market segmentation is also opening up new niches. Many rural areas, or firms in rural areas, have developed strategies for entering, and sometimes actually creating, these niches.

One strategy is to rely on local resources, natural and cultural, on the local setting, knowledge and the general social environment. Preserving and enhancing them may prove a direct and indirect source of business creation. Cheesemaking in hill farms (or similar activities) can thus assist development in these areas, just as much as the mountain environment. In some areas there is a genuine market for rural amenity (striking landscape, cultural heritage, natural resources), for instance, when associated with tourism development. Products linked with amenity can be marketed with local certification (labels, certificates of origin, producer charters and so on).

Population aging in OECD countries over the coming decades will open up a niche for rural areas. Catering for senior citizens is a potential source of activity whose scale has to be assessed 


\section{New Business in Rural Areas}

\section{BACKGROUND}

\section{The 'Territorialisation' of Employment Policies}

Sylvain Giguère

Most of the structural factors that affect employment, such as labour costs, the degree of job security and the amount of unemployment benefit, are uniform within national borders. But this is not true of unemployment and jobcreation rates, which can vary enormously, and which depend in part on local characteristics (such as the structure of industry). 'Territorialised' policies, which would take this difference more fully into account, should make it easier for the labour market to adjust and help stimulate the growth of employment.

The territorialisation of employment policies is a concept that means different things in different countries, reflecting a wide spectrum of political structures and approaches to government intervention.

One view is that territorial organisation is primarily a means of enhancing the effectiveness of national policies. This (typically topdown) approach is used frequently in France, where local authorities are able to exert some influence over how measures taken by the government are implemented.'

Another approach is based on powersharing between the various tiers of political organisation. Whether it stems from political, economic or historical factors, this division, to varying extents, enables regional governments in federal countries - such as Belgium, Canada, Germany, Switzerland and the United States - to play an active role in the labour market.

In a contrasting (bottom-up) approach to territorialisation, a variety of local interests (such as local authorities, social partners,

Sylvain Giguere is a consultant in the OECD LEED Programme.

E.mail: territory.contact@oecd.org entrepreneurs, the public employment service and community groups) pinpoint problems and possible solutions and, on that basis, submit proposals for localised action to the various echelons of government. Countries in which labour-management consultation prevails - in the Nordic countries, inter alia often use this approach to implement labourmarket policies.

At present, a number of OECD countries are in the process of territorialising their employment policies. These efforts, which are often driven by budgetary pressure, seek to enhance efficiency and, in some instances, may trigger far-reaching changes in governmental institutions. Although they may seem very different on the surface, all these changes have one thing in common: they lead to flexible territorialisation, enabling the empowerment of those involved at each stratum, according to their requirements, their potential and their abilities.

This new territorialisation affects all aspects of employment policies. A number of countries are seeking a new division of responsibilities that could vary from one part of the territory to another. Canada is one of those countries that have chosen a gradual and asymmetrical path: out of the ten provinces, four will henceforth bear full responsibility for active labourmarket policy, and four others will administer it jointly with the federal government. The outcome of these new arrangements will be felt locally, where they may give rise (as they will in Quebec) to a consolidation of the services delivered to various segments of the population.

In the United States, it is the 'Welfare to Work' reform that is having major local repercussions. The individual states, which are being given full authority to tie work requirements to welfare benefits for the disadvantaged, are making counties play a major role in implementing the new measures, especially in making available to welfare recipients publicinterest or other activities which are now obligatory. A similar measure, targeting young people in particular, will come into effect in the United Kingdom next April.

Another form of action is to organise local round tables to administer unemployment programmes in economically distressed territories. As a rule, the primary role of these partnerships is to foster consultation on projects of interest to the community, taking an integrated approach to problems of joblessness and economic development, but they would seem to be more useful yet. Drawing on firsthand knowledge of local problems, they themselves are able to set up activities (such as training, advisory services and assistance for business start-ups) which in many cases are seen as especially effective - and particularly those programmes that are aimed at groups, such as young people and the long-term unemployed, for whom it is hardest to get back into the mainstream. Governments are establishing contractual relations with such partnerships and proposing to set up similar ones throughout the country.

Local arrangements of this sort between governments and business and the unions can be found in several countries, including Belgium, Ireland and Italy. In EU countries, a number of local partnerships are supported by the European Commission in conjunction with Territorial Pacts.

1. Local Management for More Effective Employment Policies, OECD Publications, Paris, forthcoming 1998. 


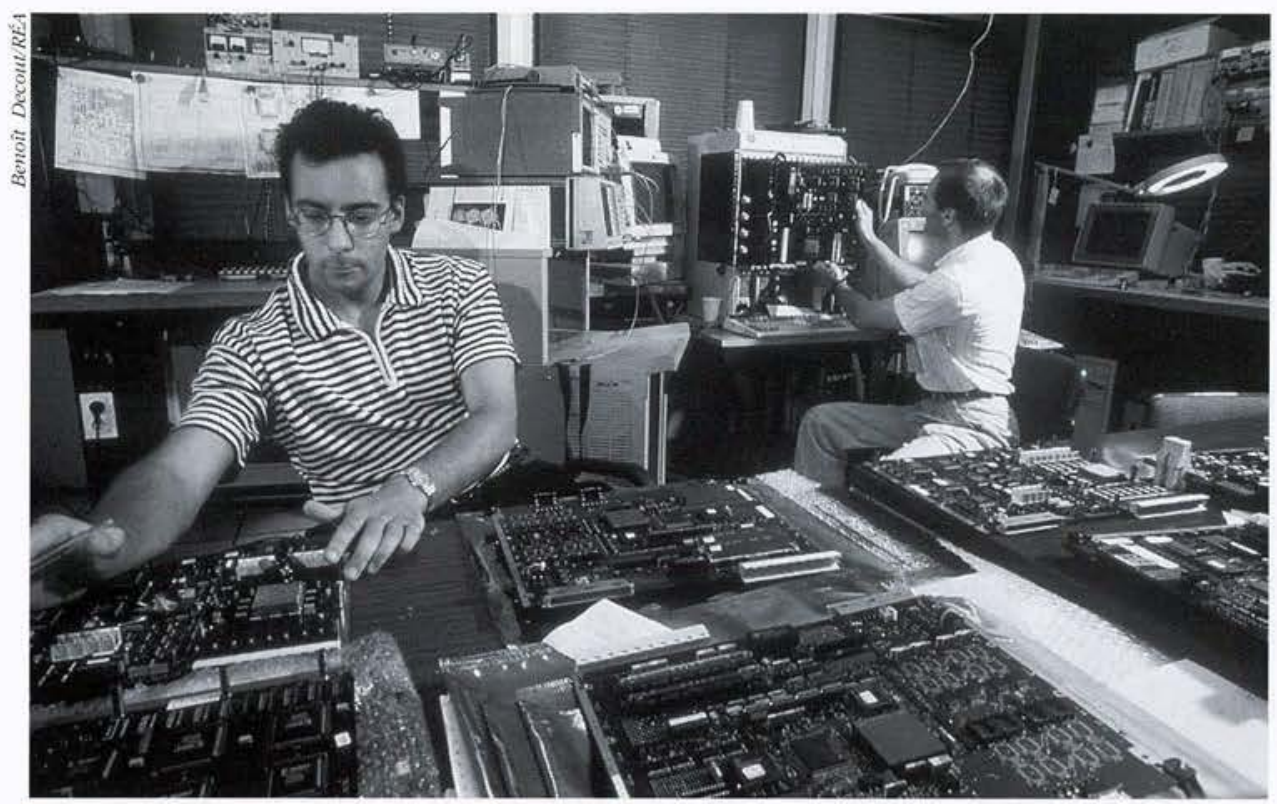

Qualified 'migrants' from towns, with their technical skills and access to commercial networks, play a vital role in business-creation in rural areas.

without delay. This social group, more mobile than earlier generations, often with more disposable income than the rest of the population, is of growing demographic and economic importance. Rural areas are already benefiting from this trend in tourism, in high season and at other periods; and senior citizens are also becoming new residents, either temporary or permanent.

Jobs in tourism are increasing at between two and ten times the pace of total employment in rural areas, but more slowly than tourism itself: the ratio of jobs in tourism to tourists is lower in rural areas than the sector average. In France (a leading market for tourism, including rural tourism), the discrepancy is $40-50 \%$ for accommodation and catering, and $65-85 \%$ for recreational services. The supply of inputs for tourism in rural areas is diverse and dispersed, so the products on offer are not always easy for the market and distribution channels to identify. The characteristics of demand for rural tourism thus have to be examined more closely to develop more

5. David Blandford and Linda Fulponi. Electronic Markets in the Agroo-food Sector;, The OECD Observer, No. 208, October/Notember 1997. appropriate products, before lending financial support to projects.

New information and communications technology can play an important role in business development in rural areas, breaking their isolation and lowering the cost of access to information and so giving impetus to business links and network-building. But to achieve critical mass (number of users, density of trade) and make use of network economies, the use of information technology has to be promoted. The risk of marginalisation for areas not joining in these moves, as well as many encouraging examples, offer an incentive to use such technologies, and particularly the Internet, which can open up new forms of marketing and information access.

\section{A New Generation of Rural Policies}

An early generation of policy for rural areas, from the 1960s on, sought to attract businesses from outside through tax measures and direct assistance tailored to the area. The next generation, starting in the 1970s, looked for endogenous development based on local potential and requirements.

The policies currently being pursued in $\mathrm{OECD}$ countries combine various aspects of earlier ones with new measures. Support systems are more complex, mixing direct assistance with arrange-

\section{Cheese-making in hill farms and similar} activities can contribute as much to economic development as the attraction of the mountains themselves.

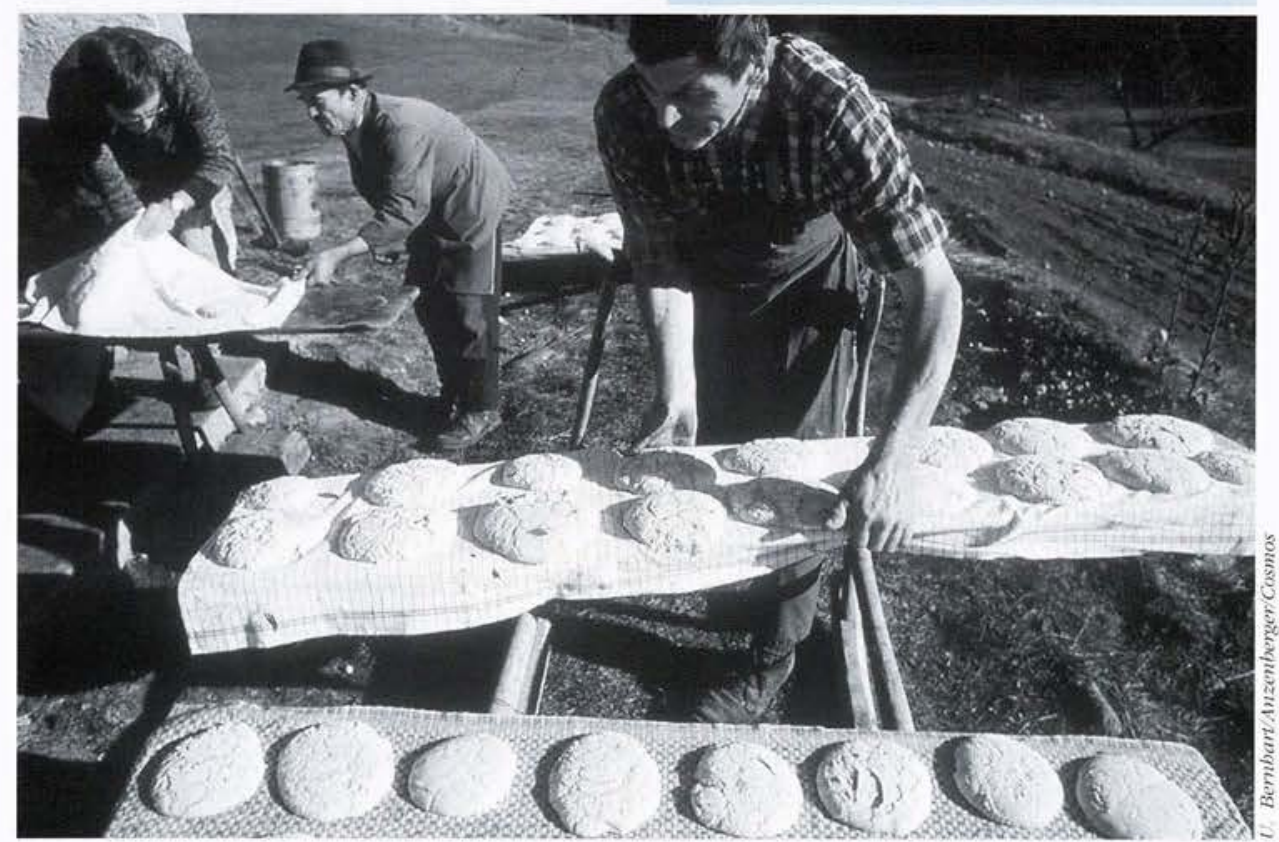




\section{New Business in Rural Areas}

ments for long-term advice and followup for new businesses. This approach brings business-creation and businessdevelopment policies closer together, and is helping to overcome the shortage of advanced services in rural areas. Informed follow-up, extending over considerable periods, substantially improves the success rate of businesses. The system introduced in Canada, for instance, has cut the failure rate from 63\% to 32\%. As earlier measures (Act 44) proved successful, Italy has strengthened its novel arrangements, which include the 'tutoring' of new entrepreneurs by experienced ones (the transmission of empirical expertise).

The new generation of policies is a combination of individual and collective approaches: overall funding, decentralised application of policy (and sometimes decen-

The aging of the population is bringing older people to rural regions, as both temporary and permanent residents. tralised design as well), partnership between the public and private sectors, due consideration of cultural, social and environmental aspects, as in the European Union's 'Leader' programme, for instance. Spreading a culture of entrepreneurship - in schools and universities, and within local communities - helps to increase the rate of business creation: in Canada, for instance, doubling it in five years (in relation to the labour force) from 7 to $14 \%$.

A number of important lessons can be drawn from evaluations of rural development policy. Co-operation between government departments is essential to focus joint efforts on businesses locally (assistance for innovation, investment, employment and exports, for instance). In addition, measures seem to operate more effectively when targeted at networks of small and medium-sized enterprises (SMEs) and not simply at individual firms. By extending business networks and devising local development strategies, resources can be pooled, business links can be consolidated, efforts can be concentrated to make more of an

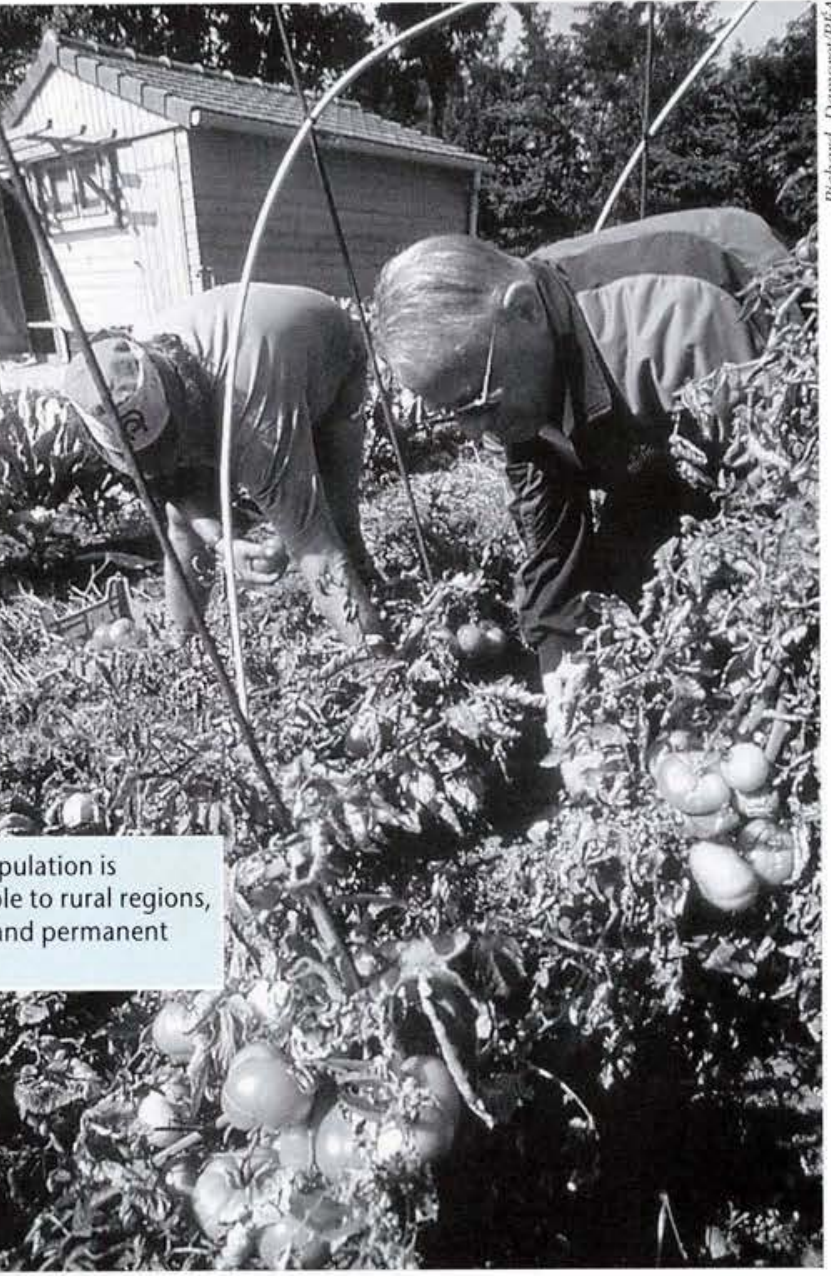

Rather than transfers to offset handicaps, government policy to foster job creation in rural areas calls for investment to mobilise overlooked or underused resources (natural resources, knowledge, dispersed production potential) so as to enhance comparative advantages (the local image, for example, collective expertise, or short response times). A package of intersectoral support for business-creation and development seems particularly effective (administrative support centres and research and advisory units available to all firms in a given area, for instance). Support of this kind has to take account of territorial factors which will help keep transaction costs down and raise the competitiveness of firms working together, as well as establish comparative advantage and set up professional networks.

Rural areas are developing. Promoting business-creation entails taking account of government and institutional reform: integrating the role of local communities and regional tiers of government more effectively; linking government action with action by private operators; and combining sectoral and

impact, and new opportunities for business creation can be much enlarged.

Decentralised policies combine a range of direct and indirect measures, aimed both at entrepreneurs and existing firms and at rural communities as a whole. They seem particularly effective. Their efficiency rises when they include permanent monitoring and appraisal systems, which make them more responsive.

Partnership between public and private sectors is seen as one of the keys for successful operation and application of programmes intended to support SMEs, together with attention to the transmission of informal knowledge and expertise. Assistance or possibly tutoring from an experienced business-manager seems essential. intersectoral measures, without neglecting the non-economic dimensions.

\section{OECD BIBLIOGRAPHY}

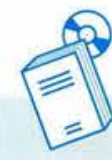

Local Management for More Effective Employment Policies, forthcoming 1998

David Blandford and Linda Fulponi, 'Electronic Markets in the Agroo-food Sector', The OECD Observer, №. 208, October/November 1997

Territorial Indicators of Employment: Focusing on Rural Development, 1996

Heino von Meyer and Philippe Muheim, 'Employment is a Territorial lssue', The OECD Observer, №. 203, December 1996//anuary 1997

Mario Pezini, 'Entrepreneurial Towns', The OECD Observer, №. 197, December 1995//anuary 1996. 


\section{Regional Policy in Mexico}

Denis Besnainou and Laurent Davezies

\section{The territorial policies of the Mexican government find their} form in the structural policies implemented in social development, decentralisation and privatisation, with a

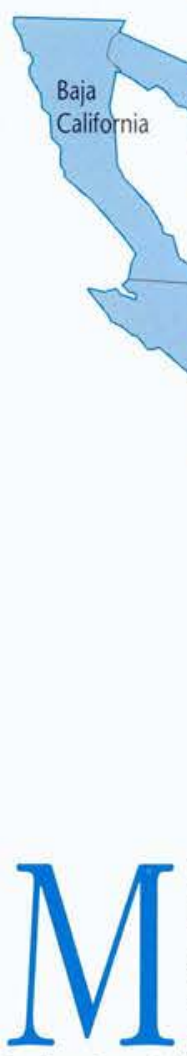

marked regional dimension aimed at correcting the imbalances between the various parts of the country.

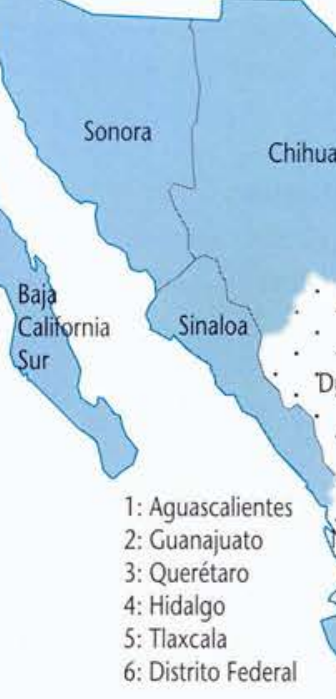

exico is a country of contrasts. It is characterised by striking geographical diversity and wide differences in natural resources. Its population is largely of mixed Indian/Spanish origin, but there are still some thirty distinct Indian ethnic groups, with their own languages and cultures. These differences are accentuated by the high urban concentra-

Denis Besnainou is a consultant in the OECD Territorial Development Service and Laurent Davezies, recently a consultant in the same service, is professor at the Université Paris XII - Créteil.

E-mail: territory.contact@oecd.org

\section{Mexico: GDP per capita (compared to national average)}

tion and the diverse types of land ownership. As a result, economic development is uneven throughout the country, leading to major disparities across regions.

Judging by the criterion of per capita GDP by state (map), in 1993 the difference between the poorest state, Oaxaca (with 3 million inhabitants), and the Federal District ( 9 million inhabitants) could be expressed as a ratio of $1: 8$. The ratio was 1:4 between Chiapas ( 3 million) and Nuevo León (3 million), which are respectively the

second-lowest and second-highest ranking states in per capita GDP (discounting the oil-producing states of Campeche and Quintana Roo).

Macro-economic developments have widened these imbalances. The peso crisis of 1994 and the recession which followed a year later had a very different impact across regions. It is the states located on the border with the United States which are most involved in export activities (maquiladora industries) - that best weathered the recession.

The currency crisis restored to industry the cost advantages it had lost over previous years as a result of the increasing overvaluation of the peso. Manufacturing employment in the maquiladoras grew almost uninterruptedly during these three years, and much more rapidly than value added. In the northern border zone it rose by $30 \%$; in the other states, where its presence is admittedly very small, it more than doubled. All things considered, the crisis of the peso increased disparities and the ensuing austerity measures reduced financial transfers to the poorest states.

. from -1.5 to -0.5 standard deviation

from -0.5 to +0.5 standard deviation

from +0.5 to +1.5 standard deviation

more than +1.5 standard deviation

\section{A Strong Territorial Dimension}

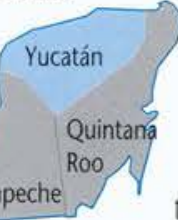

Each of the policies implemented in social development, decentralisation and privatisation has different territorial implications. In social policy, an explicit aim was the reduction of disparities.

But this aspect was not immediately taken into account in the other two policy areas,

which meant that corrective measures subsequently had to be taken.

\section{Social Policy}

In the 1990s, the Mexican government strengthened the policies aimed at creating a more equitable balance between regions, which consisted, for example, of programmes to assist the poorest urban or indigenous rural populations or specific areas. A map of the 25 priority regions was

1. Regional Development and Structural Policy in Mexico, OECD Publications, Paris, 1997. 


\section{FOCUS}

\section{Regional Funds Specialising in Social Policy}

Fund for the Promotion of Regional Development and Employment (Fondo de Desarollo Regional y de Empleo)

One-third of the resources of the povertyalleviation programme. Participants: the federal government, the states and municipalities. It is used to promote social and basic infrastructures: public works by the states, special social programmes and temporary employment or job-creation programmes. It also includes aid allocated to specific groups: indigenous communities, farm-workers, retired teachers, women and young people.

Municipal Fund for Social Development (Fondo de Desarollo Social Municipal, or FDSM)

Finances operations such as the repair or construction of rural roads and maintenance of rural medical centres. In 1996, the least developed municipalities received 230.6 pesos per inhabitant, compared with 32.5 pesos per inhabitant in more developed regions. In 1997, this mechanism should have provided the poorest regions with 246.5 pesos per inhabitant, which is $156 \%$ higher than the national average.

Regional Funds for Indigenous Populations (Fondos Regionales Indígenas)

Promote and fund the development of social infrastructure in the regions in which the indigenous population is concentrated. In 1997, some 177,000 indigenous Mexicans will have benefited from 1,948 projects supported by this programme in 23 states.

Fund to aid specific social groups (Instituto Nacional de Solidaridad, or INSOL)

Encourages social participation and collective decision-making in public social policy. Provides assistance to young people, women and the elderly in co-operation with NGOs.

Business solidarity fund (Fondo Nacional de Apoyo a Empresas de Solidaridad, or FONAES)

Goals: to help producers' organisations with projects aimed at creating jobs and providing incomes. Provides technical and financial assistance, aid and training with marketing programmes. The Fund's programmes comprise financial aid, bank guarantees and savings, training and employment. In 1995 and 1996, 2,495 small firms benefited from this programme. Of these, $31 \%$ received venture capital; the remainder received guarantee funds. During this period 23,234 permanent productive jobs were created. drawn up and a system of regional funds (box, left) enables the federal government to concentrate its social-policy spending on the poorest regions. Some changes in decentralisation procedures, particularly in education, health and poverty alleviation, have also made it possible for the states and municipalities to become more involved in the mechanisms for redistributing funds derived from taxes collected federally.

Territorial disparities in human capital are very large and, together with the lag in infrastructure and the large informal sector, have been an obstacle to attracting firms. Yet the territorial dimension of social policy is still limited, with only $8 \%$ of the 1997 budget devoted to regional and urban development. The largest items of that budget, such as education (42\%) and health (24\%), are appropriated according to rules on decentralisation that make it impossible to compensate for the handicaps of the poorest states. These states do not always have sufficient technical capacity to determine which projects are most appropriate.

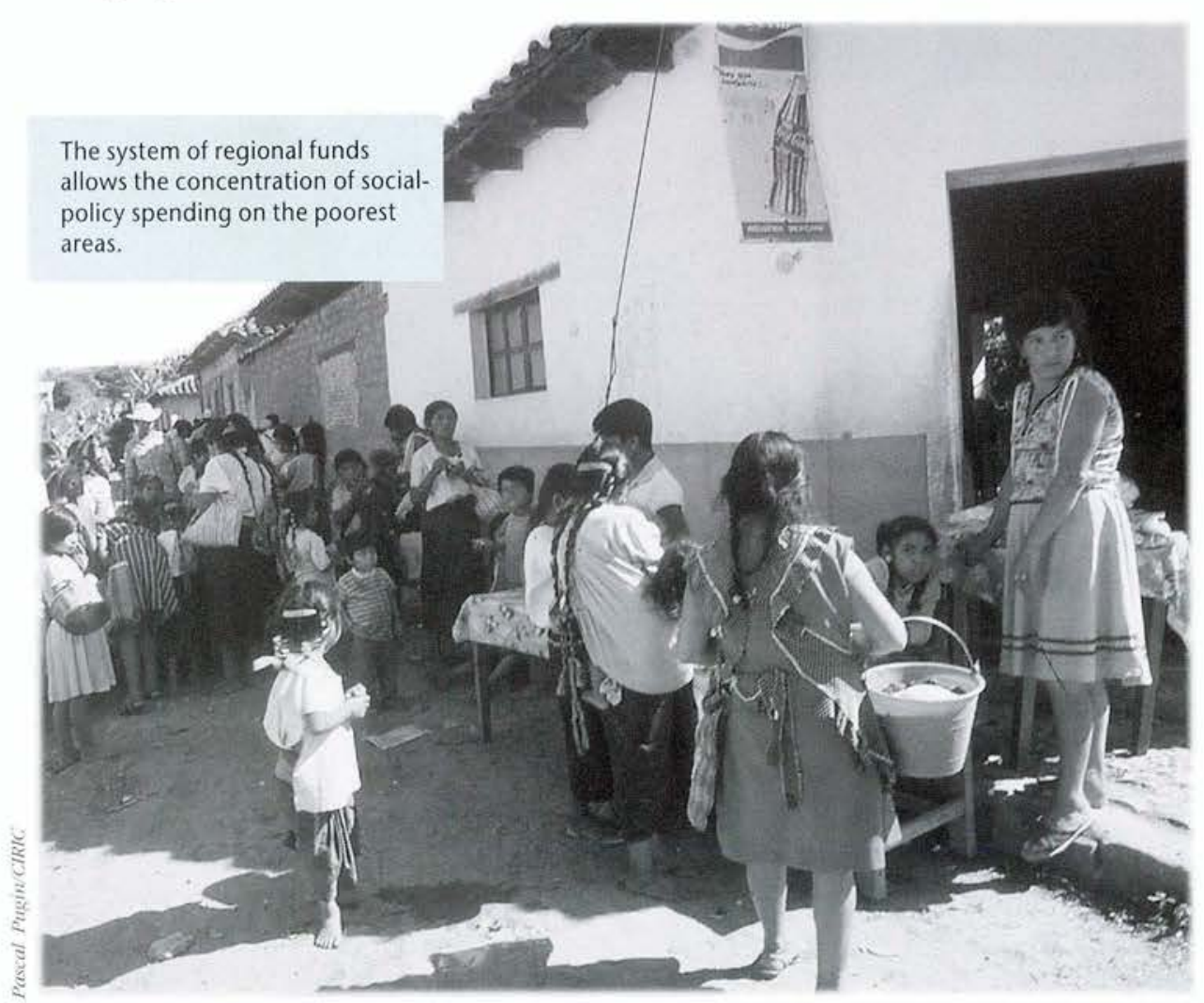

\section{Budgetary Redistribution}

Public finances play a relatively small role in the Mexican economy, although net transfers between the states are substantial (Table). Allowing that such comparisons should be treated with caution, the six richest Mexican states contribute nearly double the amount, as a percentage of their GDP, as do the net contributing regions in Europe to its poorest regions ( 7 and $4 \%$ respectively).

With the pursuit of economic growth, the process of redistribution should be made easier. Mechanisms of inter-regional solidarity should then develop with the broadening of the tax base as activities in the formal sector replace those in the underground economy. This broadening of the tax base could be further accelerated by a reform aimed at bringing into the ambit of the fisc much of the income that still escapes it.

\section{Privatisation}

The privatisation policy was launched in 1982. In the initial stages it was conducted without 
regard for territorial considerations, its primary aims being to restore competitiveness, balance budgets and modernise the legal framework for privatisation. In 1988, infrastructure (motorways, railways, ports and airports) began to be gradually opened up to foreign investment. The pace of privatisation was stepped up from 1991, extending into the banking sector, the service sector (insurance) and infrastructure, which was opened up fully to private capital.

It was only at a second stage that an attempt was made to take more fully into account the interests of territorial bodies (states, cities, ports, and so on). In spite of initial difficulties, the privatisation of infrastructure has helped to improve the quality of networks considerably (especially the motorway network). But it has also created new territorial inequalities. For example, the states located on the border with the United States, which already have extensive communication networks, have benefited most from these privatisations. At the same time, secondary networks have been neglected, which has further

\section{Table}

\section{Redistribution between States}

Distribution of deductions and expenditures

in the federal budget between Mexican states

\begin{tabular}{|c|c|c|}
\hline & $\begin{array}{c}\text { Main } \\
\text { contributors } \\
6 \text { states }\end{array}$ & $\begin{array}{c}\text { Main } \\
\text { beneficiaries } \\
17 \text { states }\end{array}$ \\
\hline $\begin{array}{l}\text { Population } \\
(\% \text { of total) }\end{array}$ & 26 & 41 \\
\hline GDP ( $\%$ of total) & 43 & 27 \\
\hline $\begin{array}{l}\text { Balance of federal budget } \\
\text { ( } \% \text { of GDP } \\
\text { of the states concerned) }\end{array}$ & -7 & 11 \\
\hline $\begin{array}{l}\text { Balance of federal budget } \\
\text { (\% of national CDP) }\end{array}$ & -3 & 3 \\
\hline
\end{tabular}

The six states whose negative balance in the federal budget is more than $1 \%$ of their GDP are, in increasing order: Distrito Federal, Nuevo León, Chihuahua, Quintana Roo, Baja California and Jalisco. The 17 states whose positive balance in the federal budget is more than $5 \%$ of their GDP are, in increasing order: Tabasco, Tlaxcala, Oaxaca, Chiapas, Aguascalientes, Zacatecas, Colima, Puebla, Durango, Yucatán, Campeche, San Luis Potosi, Hidalgo, Nayarit, Michoacán, Baja California Sur and Veracruz.

Source: Instituto Nacional de Estadística Geografía e Informática

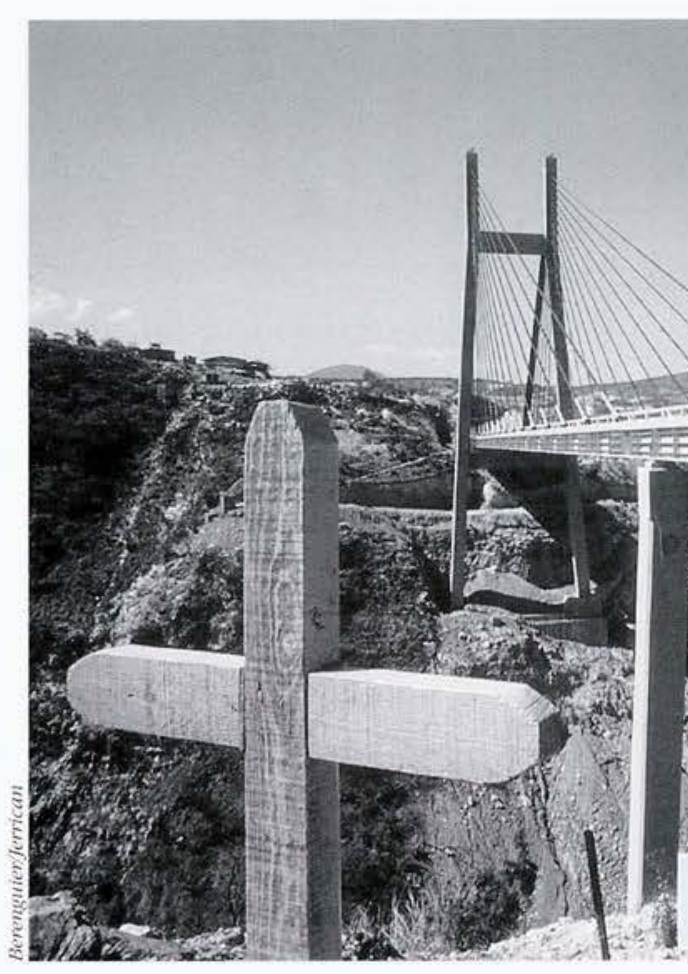

diminished the growth potential of areas that are connected to the rest of the country only by the communication routes linking Mexico City with the US border. As for ports, such as Vera Cruz, and airports, such as Mexico City and Puerto Vallarta, privatisation brings the opportunity of establishing regional, even international, centres for development by making sure they form part of international networks.

It is difficult to estimate the general impact of the social-development, budgetary-redistribution and privatisation policies on the regional economic and social inequalities. Broader decentralisation of federal decision-making powers towards the states and municipalities and more effective co-ordination of territorial bodies with a view to improving economic performance in terms of wage costs and productivity should help reduce such imbalances.

The disparities in GDP are still substantial and can be ascribed to an imbalance in the geographical distribution of activities. Regional policy can reduce

\section{OECD BIBLIOGRAPHY}

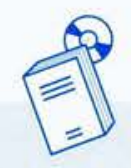

Decentralisation and Local Infrastructure in Mexico: A New Public Policy for Development, forthcoming 1998

OECD Environmental Performance Review: Mexico, 1997

Regional Development and Structural Policy in Mexico, 1997

OECD Economic Studies: Mexico, 1997

Cérard Bonnis and Wilfid Legg, The Opening of Mexican Agriculure', The OECD Observer, №. 206, June//uly 1997

Christian Schricke, 'Mexico, 25th Member of the OECD',

The OECD Observer, No. 188, June/July 1994

Bénédicte Larre and Bernard Wacquez, 'Mexico',

The OECD Observer, №. 188, June/July 1994. 


\section{Entrepreneurship}

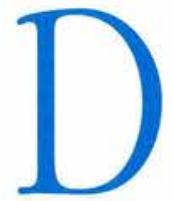
uring the early stages of reform, the government of the Russian Federation and its advisors concentrated primarily on macro-economic stabilisation, perhaps neglecting the importance of small business as a buffer to the difficult process of structural adjustment. Although the number of small and medium-sized enterprises (SMEs) has been growing, filling important gaps as small-scale providers of services and consumer goods, and absorbing some of the redundant resources from heavy industry, small entrepreneurs in Russia are nonetheless finding survival quite difficult. ${ }^{1}$

The historical context provides a partial explanation. The freedom implicit in an economy composed of thriving small firms was incompatible with a planned economic system, and the private ownership they presuppose was, of course, absent in the Soviet system. Moreover, the theoretical background of planned economies was entirely based on economies of scale, in which there was no role for small firms; indeed, the command system would have been even more inefficient if it had to deal with small units.

Compared with other economies in transition, these elements have been more pronounced in Russia and present for much longer. Communism lasted for forty years in Poland and Hungary, and forms of private property continued to exist during that period. In Russia the communist system endured for over seventy years, with much deeper effects on the economic structure and social habits of the country.

The situation in Russia is made more complex by the high degree of informal entrepreneurship, by individuals trying to escape heavy regulations and taxation or simply to survive through the black-market economy in periods of high inflation and recession. Many have started activities that are not registered, and

Paul Paradis specialises in entrepreneurship, local and regional development in the countries of central and eastern Europe in the OECD Territorial Development Service within the framework of the Centre for Cooperation with Economies in Transition. Almoro Rubin de Cervin works as a consultant in the Territorial Development Service.

E-mail: territory.contact@oecd.org

Paul Paradis and Almorò Rubin de Cervin

Entrepreneurship is a vital element in the transition to a market economy. It contributes to economic growth and social cohesion as well as the democratic process. Setting up a successful small business raises awareness of the benefits of a market economy; and with the expansion of the class of small entrepreneurs, more and more people gain a direct stake in the maintenance of democracy.

are functioning in sectors that lack regulation and where the possibility for intervention by criminal organisations is larger. The general weakness of the rule of law in the Russian Federation is a critical impediment to small businesses which are extremely fragile in even the most robust of economic circumstances.

\section{How Many Entrepreneurs?}

Macro-economic stabilisation and the creation of a positive legislative and regulatory framework might lead to the entry into the official economy of a large number of small firms that are hidden today. The lowest estimate of the size of non-registered economic activities is around $25 \%$ of GDP. Other sources put forward much higher figures, up to $50 \%$, possibly employing up to 30 million workers.

In 1990 small firms (mainly in the form of cooperatives) numbered 45,000 ; by the end of 1991 there were $268,000 .^{2}$ The next two years witnessed another considerable increase, up 200\% in 1992, and 150\% in 1993. From a peak of close to 900,000 in 1994 , growth in the number of small firms has slowed since 1995 , and stood at approximately 842,000 in January 1997, a a low figure for a country of 149 million inhabitants. Poland, with 38 million inhabitants, has more than one million SMEs, and Hungary, with 10 million inhabitants, has more than 500,000 SMEs.
The main areas of economic activity of small enterprises in Russia, accounting for $85 \%$ of the total number in 1995 , are trade, with $43 \%$ of total firms, construction with $17 \%$, manufacturing with $15 \%$ and scientific and market services with $10 \%$.

The increase in the number of SMEs in construction has been impressive. The firms involved in this sector displayed a high degree of adaptability in the face of the difficulties of 1994-95, which included decreasing output and high inflation and interest rates. This is especially true in regions such as Kostroma and Novgorod, and in the Altai Republic. As industrial and municipal housing construction activities slowed, these firms developed the construction of private housing (mainly in rural areas) and rebuilding of offices and warehouses.

At the beginning of 1991, only one-third of the small enterprises observed by the Goskomstat

1. Entrepreneurship and Small Enterprises in Russia, $O E C D, 1998$. This and related publications are available free of change from the OECD Territorial Development Service and on the Internet, at the following address: wuw oecd.org/tds/tspub, htm.

2. These figures are from Goskomstat, the State Committee for Statistics. Comparability across years on S.ME statistics is poor, reflecting frequent institutional changes within the Committee and an evolution of methods. Goskomstat is working to improte the data collection concerning small firms.

3. The employment definition of SMEs was modified by Goskomstat in 1996, so that this figure is not comparable with those from 1995 and earlier. The following are the present employment criteria for the number of salaried workers: industrial production, construction and transport: 100 (200 in 1995); agriculture, science, and scientific senvices: 60 ; retail, services: 30 ; wholesale trade and other services: 50 . 


\section{in the Russian}

\section{Federation}

were privately owned. By the end of 1993 , private establishments already made up two-thirds of the number. In April 1995 only $4 \%$ of all SMEs had preserved their state-owned status, including federal and municipal enterprises. And 84\% of the remaining $96 \%$ of all SMEs are under private ownership, $1 \%$ under the ownership of various public organisations, and $11 \%$ under mixed ownership.

Russian SMEs are characterised by a large proportion of very small enterprises, with an average number of employees per firm of ten between 1993 and 1995. At the beginning of 1996 nearly 9 million workers were employed full-time in small businesses, 1.3 million part-time and 3.6 million contract workers, making a combined total of 13.9 million. SMEs in industrial production and construction are usually larger (18-20 full-time workers on average), and account for almost $60 \%$ of total employment in the SME sector.

The heaviest concentration of SMEs (30.5\% of the total) and their employment ( $28 \%$ of total employment in small firms) is observed in the
Central District, with the city of Moscow as the clear leader, followed by the districts of North Caucasus, Ural and West Siberia. Small enterprises are concentrated in the administrative centres and large urban areas.

Since small firms are new to the Russian Federation, entrepreneurs constitute a new social category and their emergence is complicated by the tendency to link them with criminal organisations. Although such organisations are obviously active in the Russian economy, such a link is simplistic and, in many cases, even erroneous. Many honest people in Russia have become entrepreneurs - in western terms - and in a much more difficult environment.

One of the problems most cited by the entrepreneurs surveyed is taxation, a familiar complaint from small entrepreneurs in OECD countries. In Russia, although corporate and individual income-tax rates are comparable to those in other countries in transition, the addition of discretionary regional and local charges makes the real fiscal burden on entrepreneurs particularly heavy. New and constant adjustments

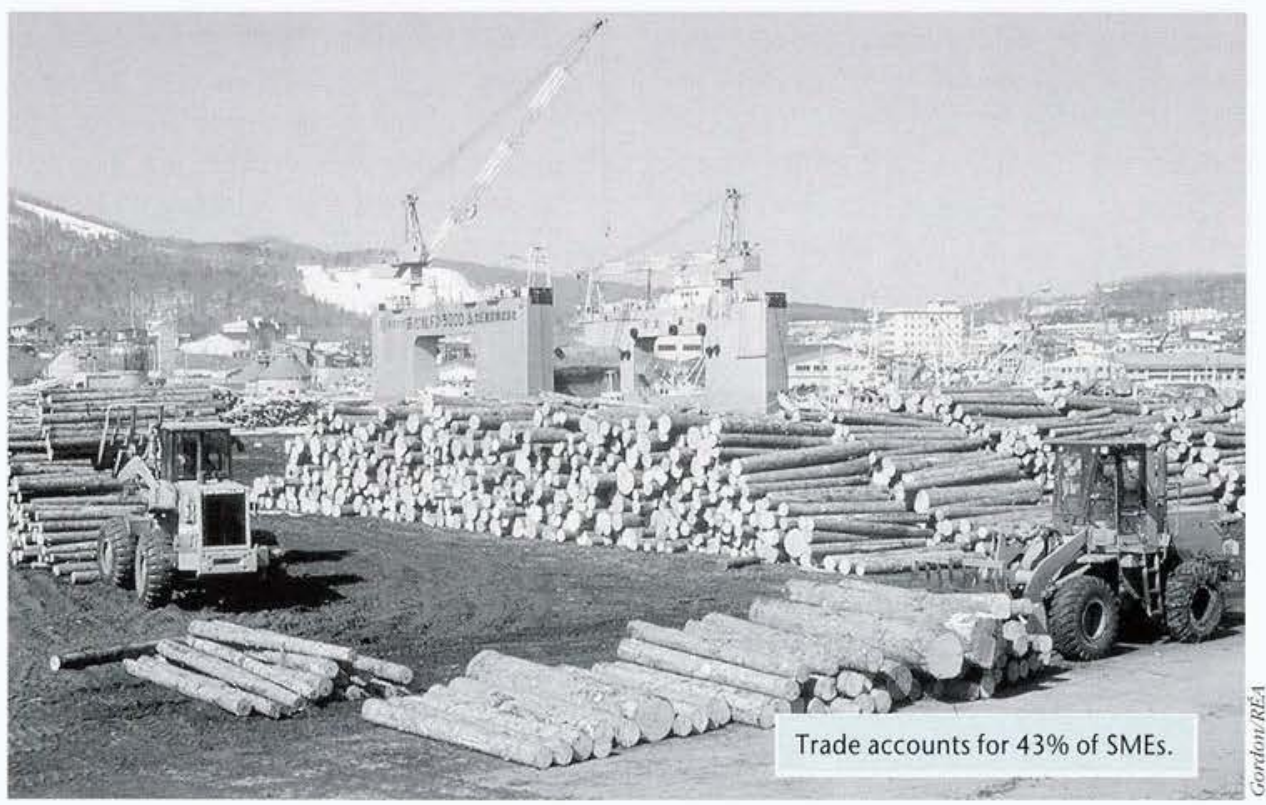

in tax rules, sometimes even retro-actively applied, are common occurrences.

The lack of capital, likewise, renders the creation of enterprises a difficult task, particularly in manufacturing. Entrepreneurs are usually able to cover $15-20 \%$ of the initial costs from their personal savings. Less than one-half are able to apply for bank loans, and a very low percentage of small enterprises actually receive credit. The leasing of equipment is in the early stages of development, and credit conditions are very difficult for starting a business: loans are small on average (under $\$ 100,000$ ), with maximum maturities of three months, at market interest rates of up to $150 \%$.

Inter-enterprise arrears also arise from time to time and jeopardise small enterprises. As a result, non-bank high-interest credit and other informal and semi-legal forms of financing are widespread. 'Black' mutual-aid funds (chernye kassy) are collected by some enterprises in order to cope with financial difficulties.

The unstable legislative and regulatory framework is yet another of the major obstacles for new entrepreneurs. Property rights, labour relations and many special SME regulations, such as credit co-operatives, leasing and other arrangements, are awaiting legal specification. Such loopholes and lacunae are accompanied by the frequent absence of enforcement mechanisms.

Since the influence of regional and local authorities in the regulation of economic life was high in the Soviet Union, it is hardly surprising that bureaucratic interference into SME economic activities - in the form of barriers and delays, excessive control and reporting requirements, corruption and bribe-taking - is frequently cited by Russian entrepreneurs as an obstacle to their development.

\section{Supporting the Small Business}

The definition of small firms has changed several times in the last five years, as have the ministries and agencies in charge of the implementation of the policies affecting them. The situation was stabilised by the passing of a general 


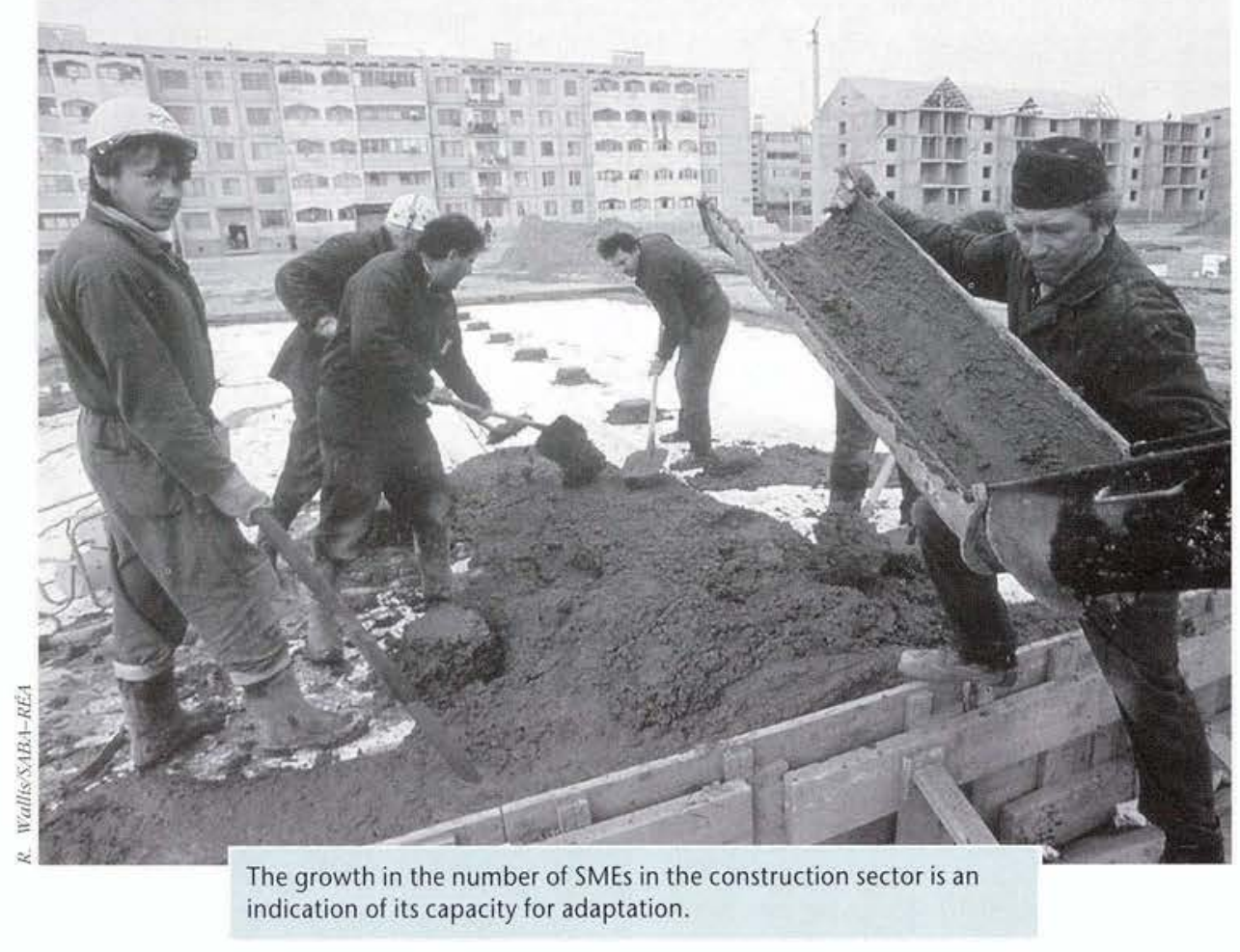

Law on State Support of Small Enterprise in the Russian Federation in June 1995, and the creation of a new ministerial body, the State Committee for the Support and Development of Small and Medium Enterprises (SCSME), whose task is the co-ordination of all the issues affecting small firms.

According to the Law of June 1995, the Russian Government must submit an SME Support Draft Programme to the Parliament every year before the Federal Budget submission. Federal and municipal SME Support Programmes are supposed to include measures for infrastructure development and SME support on all strata of government, and to integrate vulnerable social groups (disabled, women, young people, retired military officers, unemployed, refugees, discharged prisoners) into the SME sector. They should also include the allocation of budget resources and tax privileges for SMEs; and facilitating access by SMEs to information and new technologies, the purchase of equipment and renting of business premises. The Law also urges the government to allocate not less than $15 \%$ of state orders to small enterprises and to encourage SME participation in export and import transactions. The degree of effectiveness and implementation of this set of policies is still unclear.

The 1996-97 Programme for SMEs (coordinated by the Ministry of Economy, but actually drafted by the SCSME) includes creating a legislative and regulatory basis for small firms; financial and investment support; supporting infrastructure development; scientific support and personnel training; and social security. Other priorities are the stimulation of investments (through risk-capital funds set up by regional authorities and leasing of equipment) and the promotion of innovative and R\&D business linked to university and research-based towns like Tomsk in Western Siberia. Other central aspects are the transition from federal funding to the principle of variety in sources, with more emphasis on regional programmes and a shift from the direct support of SME projects to the establishment of guarantee funds.

The Programme also aims to develop a minimum infrastructure in every region including SME Support Foundations, banks and insurance companies working in the small-business sector, business incubators, development agencies and training centres, and information networks. According to the initial estimates, the cost of the Programme was 883 billion rubles ( $\$ 190$ million) -707 billion from the federal budget and the rest from regional and non-budget sources. Evidence of the implementation of these programmes is scarce, and it appears that much of the work is being undertaken by the regions, for example, through the regional SME Support Foundations and governmental committees in regional administrations established in more than 70 regions to favour enterprise development.

More important in size are programmes funded by international donors. By the end of October 1995, 156 programmes to provide technical and financial support to SMEs had been funded in Russia by a total of 53 donors: governments and international financial organisations and institutions (EU-TACIS, USAID, EBRD and others). Germany, for example, is carrying out
170 projects (at a cost of 75 million DM), $60 \%$ of which assist SMEs. These projects vary in length from a month to three years, and it will be a challenge for Russian authorities to sustain these initiatives once the funds from the donors are reduced.

On paper, the Russian authorities, national as well as regional, have designed a complete set of policies and programmes for the development of entrepreneurship. But the distance from design to implementation is considerable, and the situation differs from region to region. In some cases, especially where high-skilled workers and scientific researchers were available, small enterprise has flourished, at least in relative terms.

International technical-assistance programmes have contributed to raising the awareness of the importance of entrepreneurship in the economy, but their capacity for providing funds is limited. One of the challenges facing donors has been how to design programmes that are appropriate to unfavourable local conditions for small businesses in the Russian Federation. For example, implementing market-based lending programmes is extremely difficult, but creating subsidy-based programmes may contribute to a culture of dependency.

Although Russia has made progress in the creation of a legal and regulatory framework for entrepreneurs, it is not yet enough. The emergence of a vibrant private sector based on small firms in the Russian Federation is a long-term process with which policy dialogue with OECD governments should help. Respect for the rule of law and business ethics will be critical to the survival of new entrepreneurs.

\section{OECD BIBLIOGRAPHY}

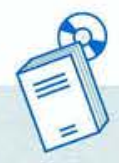

Entrepreneurship and SMEs in Transition Economies: The Visegrad Conference, 1997. 


\section{Patents, Innovation and Globalisation}

Georges Ferné

Patents aim to reconcile a socio-economic necessity - support for the creation and diffusion of new technology - with the interests of the inventor. This is the principle on which a patent can be obtained to protect an invention with an industrial application. But the combined forces of globalisation and technological progress are beginning to undermine the effectiveness of patents. Differences between national systems make patenting an increasingly complex and costly exercise for inventors. What impacts will such differences have on the international system of innovation?

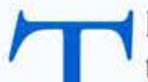

he history of patents dates back to the Letters Patent first issued in England in the fourteenth century as a means of protecting inventions. The way in which a patent works is quite straightforward: the patent-holder is granted a de facto monopoly on the use of his invention for a certain period, usually 20 years. In return, the inventor must disclose his invention. The patent must therefore be made available to the public and must contain a full description of the invention. The information disclosed must be such that other inventors can improve on the original invention or develop other approaches that can also be patented.

The engine driving this cumulative process of technological progress is clearly that of competition, and the patent system has therefore been designed to act as an incentive for R\&D and innovation. It is undoubtedly the simplicity of the

Georges Ferne works in the Science and Technological Policy Division of the OECD Directorate for Science, Technology and Industry.

E-mail: dsti.contact@oecd.org patent system which has ensured its longevity by allowing the system to be built upon and adapted over the centuries: adoption of the patent system by an ever-increasing number of countries; diversification of the instruments used to protect intellectual property (in addition to patents, development of copyright, industrial models, brand names, trademarks, and so on); adjustments to take account of new technologies (software, biotechnology); harmonisation of national systems as a result of growth in trade.

\section{Growing Internationalisation}

Each of the industrialised countries, particularly after the Industrial Revolution and from the nineteenth century onwards, established its own patent system tailored to meet its industrial and technological development strategy. The developing countries did not set up such systems until a much later date - in many cases, indeed, not until very recently. The countries which shifted to a market economy in the late 1980s have made major efforts to put in place systems comparable to those of the industrialised countries. The differences between the systems in place in the industrialised countries reflect the priority given either to successive improvements in particular areas of technology (as in Japan, where the scope of patents is relatively limited and restricted to specific technical novelties) or to major creative leaps (as in the United States, where patents are much broader in scope and where a single application may cover an area that in other countries would require several patent applications).

A system for protecting intellectual property rights therefore requires a well-defined industrial strategy and one that can evolve over time. One system is not necessarily 'better' than another: local circumstances have to be taken into account. The aim should not be to try and adapt systems to fit some ideal model, but rather to strike a balance between national requirements and the constraints of globalisation and the emerging global innovation system.

The growth in international trade since the last century has led to ever closer co-ordination of national patent systems, a role ensured mainly by the World Intellectual Property Organization (WIPO). ${ }^{2}$ The growing integration of economies is accelerating this process. Firms are increasingly starting to operate in regional if not world markets, and are adopting new strategies towards alliances and competition that are often deter-

1. Intellectual Property Rights: Patents and Innovation in the International Context. OECD. Paris, forthcoming 1998. available free of change from the Sctence and Tecbnological Policy Division of the OECD Directorate for Science, Technology and Industry.

2. The WIPO uas offictally established in 1967. pursuant to the Berne Convention of 1883, under the auspices of the United Nations, wbich assigned responsibility for administering an intemational secretariat to the Federal Gotemment of Switzerland. The cturrent nole of the WIPO is to ensure the implementation of the rules and procedures set out in treaties relating to the international protection of inventions to allow imentors to enforce their rigbts in the countries concerned. 


\section{Patents, Innovation and Clobalisation}

mined by the range of complementary or competing technologies in their possession. Examples of this trend can be seen in past competition over computer systems and mobile telephone technology or in the current race to secure a share of the new DVD (Digital Video Disk) market. Patents, like other instruments for protecting intellectual property such as copyright. standards and brand names, are thus very real assets in firms' strategies towards partnerships or competition.

In most OECD countries, a growing share of patents - the majority according to official figures, which may overstate matters ${ }^{3}$ - are filed by non-residents. Out of 27 countries, the non-resident/resident ratio is lower than 1 only in the United States (0.91), Japan (0.16) and the Czech Republic. The three main patent offices (those of the United States, Japan and the European Union) have reported substantial growth in demand for international searches to determine the novelty of the invention for which a patent application has been filed. Search requests have risen from 36,719 in 1994 to 41,564 in 1995, a gain of $13.2 \%$. The patent system is clearly becoming increasingly internationalised.

The patent co-operation treaty of 1970 was designed to take account of this development. It introduced a procedure, under the auspices of the WIPO, intended to create a 'one-stop shop' for the submission of requests for international searches, which are then transmitted to the relevant national patent offices of the countries selected by the applicant.

A number of regional offices have been established in North America (under the NAFTA), Africa and Europe. The responsibilities of these offices vary, ranging from collaboration on the harmonisation of rules and procedures to the granting of regional patents.

The European Patent Office (EPO), which has its headquarters in Munich, plays a major coordinating role: by processing the applications to individual national offices, it can issue patents valid in all the Member States of the EU, although these are not 'European patents' in any strict sense. The delegation of powers by national patent offices to a single body that would alone have the authority to issue such patents recognised by all Member States of the EU through a 'one-stop' procedure is still some distance in the future - although hopes are already being entertained that such a system might be introduced on a global basis. Obviously, it would dramatically simplify existing procedures, as well as helping to overcome discrepancies in the management styles of national patent systems, differences that might sometimes appear trivial but that can often lead to needless delays, friction and litigation.

Of course, the major multinationals, along with a few small firms at the forefront of the

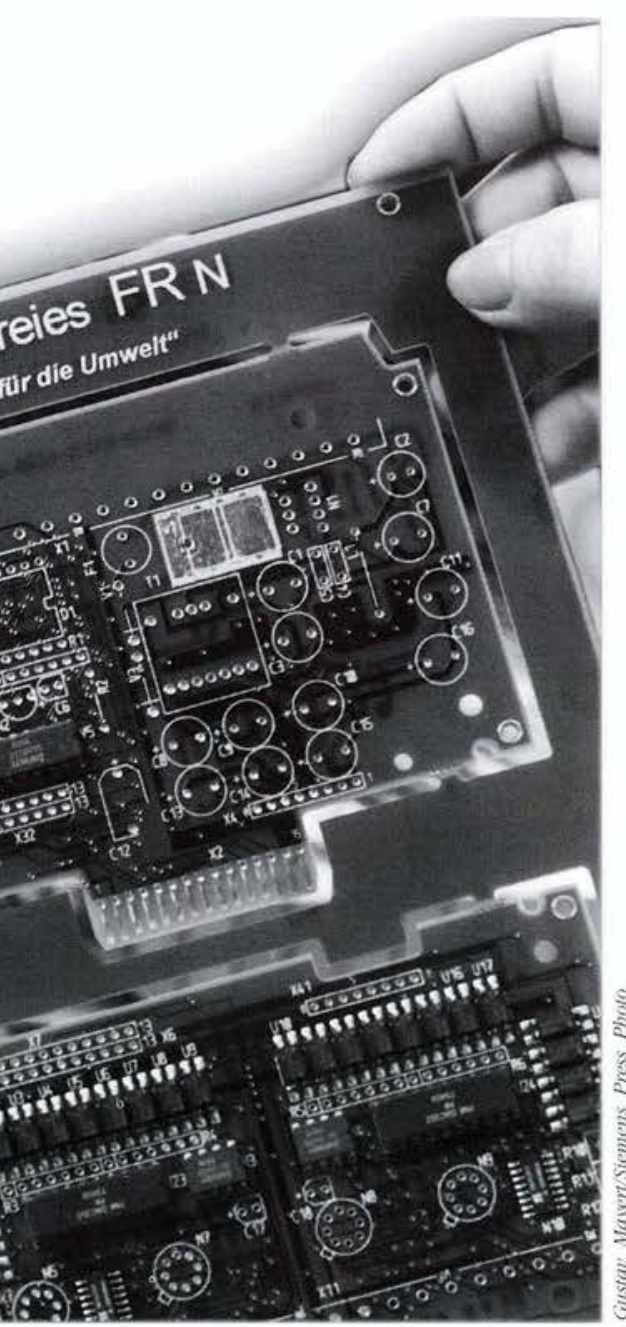

From the phonogram to computer circuitry patents have always had to move with technological and economic advance. 
movement towards internationalisation, would be the first to benefit from such a system. Firms like this find the current system increasingly unacceptable. Their commercial horizons are transnational and it is in this context that they want to exploit their innovations more effectively. Yet the activities of most firms are still restricted to national if not local markets. These firms still find their interests more than adequately protected by national patent systems tailored to meet their specific requirements. But as competition from foreign firms grows fiercer, inadequacies in international protection for their rights may well start to work to their disadvantage, prompting increased calls on their part for the harmonisation of patent regimes.

In 1993, a major step was taken towards the world-wide harmonisation of legislative and regulatory practices with the Agreement on TradeRelated Aspects of Intellectual Property Rights (the TRIPS Agreement negotiated under the GATT) ratified by over a hundred countries. ${ }^{4}$ This agreement lays down a number of minimal standards and defines the performance obligations of signatories in enforcing intellectual property rights, although many differences still remain between countries.

\section{Increasing Technological Complexity}

Since the dawn of the industrial age, patent regimes have had to adapt to changes in the technological and economic environment. Protecting manufacturing processes (which originally could not be patented) thus came to be perceived as being equally important to industry as the protection of products. New areas of knowledge, such as pharmacology, have required the scope of protection to be broadened. Over the years, new technologies, ranging from the phonogram to cordless phones, software programs and biotechnology, have required major adjustments to be made to the patent system. At the same time, the modern technological system has also changed the nature of the parties concerned. The lone inventor has become an exception; it is innovation by firms that is now the rule. And the quickening pace of technological progress is creating new demands.

A system of protection based on the granting of copyright was initially put in place to take account of the growing importance of computer software. But it posed several problems. Software programs, strictly defined as a series of coded instructions, are increasingly embedded into specific items of hardware which are themselves patentable. Patents can also be filed for software applications (financial services, for example) which may be held either to constitute an 'inventive leap', and are therefore patentable, or as non-patentable commercial ideas. Approaches to this issue vary from one country to another, although the true scale of the difficulties it creates for the software industry has yet to be properly determined.

In the biotechnology sector, the patenting of developments in genetic engineering and gene isolation has posed many problems. The patentability of living matter is a highly contentious issue. The TRIPS Agreement recognises the patentability of micro-organisms, microbiological processes and plant varieties under certain conditions, although application of this principle varies from country to country. A broader interpretation of the principle, for example, has made it possible to grant patents for the 'oncomouse' (a genetically engineered mouse) in the United States and Europe. Controversy still reigns over the patentability of human genes and of plant and animal varieties that have not been produced through microbiological processes.

New technologies therefore modify the scope of patentable inventions - and they can also, by their very nature, alter the way in which the patent system works. Electronic networks such as the Internet open up new channels for marketing and as a result new world-wide opportunities for fraud and counterfeiting. ${ }^{5}$ By providing

3. Trilateral Statistical Report, European Patent Office, Munich, 1995. The precise importance of these data is uncertain since arbitrary factors (such as reductions in the cost of filing patents) can sometimes encourage inventors to patent their inventions in a larger number of countries than they might originally bave intended. 4. TRIPS Agreement, 1993, Article 27.

5. Elizabeth Lynch Protecting Consumers in the Cybermarket; The OECD Observer, No. 208, October November 1997. on-line access to patent data, such network technologies are increasing the speed - to an extent that some inventors might find excessive - at which information about inventions is disseminated.

\section{Differences in National Regimes}

Major differences therefore remain between national patent systems, the main difference being that such systems are at different stages of development. Countries with a long-standing tradition of patent protection already have an appropriate array of legislative and regulatory instruments in place, together with wellestablished or even specialised courts and other means of settling disputes (arbitration, for instance). Other countries that are either still developing or in the process of adapting to a market economy are starting to introduce similar systems - the TRIPS Agreement encourages such countries to do so by providing for a period of transition.

Other differences might appear trivial. They concern primarily the patent-holder, who may be either the first person to file a patent or, as in the United States, the original inventor. In the first case, priority is determined by the date on which a formal application is made to a patent office and can be challenged only if the invention is subsequently proved to have been stolen; in the second, priority may be challenged if it can be proved that the patent applicant was not the first person to make the invention, even if the original applicant had no intention to defraud. This second approach, which might seem fairer, offers more scope for potential conflict and increases the uncertainty about the validity of a patent, since a competitor can present himself at any time to dispute the priority of the patent. In practice, this rule is applied to firms well outside the territorial boundaries of the United States, and any inventor who wishes to safeguard his rights in the US market - that is, by filing a patent in the United States - must take this into account.

The rules of disclosure, as in the case of patent applications, also vary. In Japan and Europe, 


\section{Patents, Innovation and Clobalisation}

inventions are published within 18 months of a patent application being filed, whereas in the United States patent applications remain confidential until the patent is actually awarded, usually within two years of filing. But a number of procedural devices allow applicants to prolong this period and foreign competitors have criticised the US practice of creating pending or 'submarine' patents which create uncertainty over the validity of patents filed and published in the normal manner.

Problems relating to disclosure do not end there. If patentability is based on the novelty of an invention, information regarding that invention should not, in principle, be disseminated beforehand. But some countries (Australia, the United States, Japan and Russia) have introduced a grace period in which the disclosure of findings does not preclude the award of a patent provided that an application is filed within twelve months of such disclosure, thus satisfying the concerns of researchers who wish to publish their findings as soon as possible. There has been mounting pressure for such a system to be introduced in other countries, too. For the time being, publication in a country where such grace periods are legal can jeopardise the patentability of the invention in another.

There are many other differences in patent systems. For example, the assignment of property rights to an invention among employees and employers (firms, universities, government research laboratories, and so on); the procedures whereby a competitor can challenge a patent application, and the time allowed for such opposition; or activities such as pharmaceutics, in which the commercialisation of products can be held back by licensing procedures so slow that in some countries the term of the patent (usually 20 years) has to be extended.

More generally, the cost of managing a portfolio of patents is beginning to have a direct impact on the overall strategy of firms. Not only do the costs of patent applications and the ensuing yearly maintenance fees vary from one country to another (until this year, a patent application in Japan cost four times less than one to the European Patent Office, approximately $\$ 2,000$ compared with over $\$ 8,000$ in Europe, although this difference has now been reduced with a recent cut of around 30\% in European patent costs); in many cases applicants must also bear the supplementary costs of translation and legal advice. In addition, procedures in some countries tend to encourage litigation, which can prove to be highly costly. A typical lawsuit in the United States could cost anywhere between $\$ 25,000$ and $\$ 200,000$, or even up to a million dollars in some cases, depending upon the complexity and length of the litigation, cost of hiring consultants and experts, and so forth.

\section{Impacts on Innovation}

All these differences in the way in which national patent systems are managed pose a number of problems for the performance of research and exploitation of research findings, at a time when the process of internationalisation is creating new forms of partnership between researchers in universities and industry in all countries.

The possibility of publishing results in some countries but not in others (as in the period of grace), for example, can act as a brake on collaborative partnerships between universities and industry, which will usually wish to delay any type of disclosure for as long as possible. By the same token, collabo-

6. See, for example, Wesley Cohen, Richard R. Nelson and Jobn Walsb, Appropriability Conditions and Why Firms Patent and Why They Do Not in the American Manufacturing Sector, presented at the OECD Conference on New Science and Technology Indicators for a Knowledge-Based Society, 19-21 June 1966 (available free of charge from the Science and Technological Policy Division of the OECD Directorate for Science, Technology and Industry); Dominique Geullec and Isabelle Kabla, The Patent as an Instrument for the Appropriation of Technology, Ểudes économiques et statistiques, No. 1 . INSEE, Paris, Marcb 1996. ration between researchers from different institutional environments may be hampered by the wide variety of rules relating to the assignment of rights among employees and employers, patent-application procedures, recognition of the role of the inventor, assignment of exploitation rights, licensing, allocation of profits, and so on. In many cases, universities are given the patent rights (subject to

the award of a

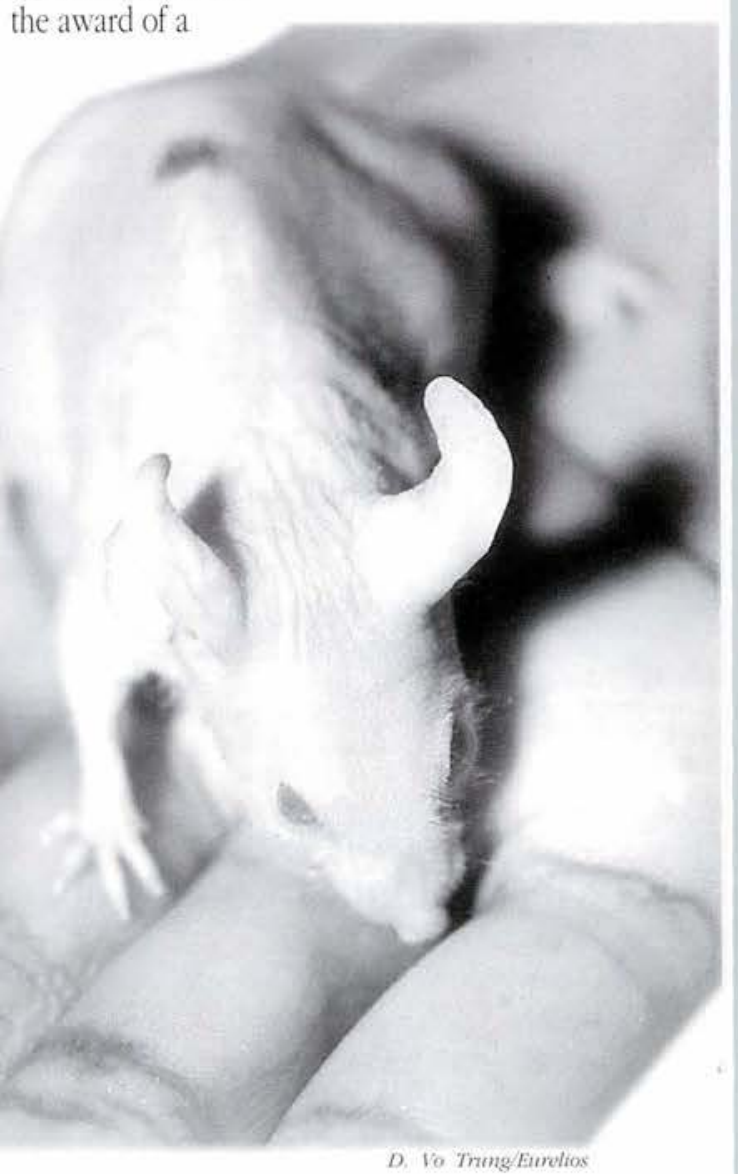

licence to their partners); but many higher education establishments in OECD countries have practically no experience in this domain. Indeed, in undertaking research for profit, how far can universities go without jeopardising their primary mission?

An additional complication lies in the fact that some countries now accept joint applications for co-ownership of patents, while others prohibit such practices. This may well make the management of patent-application strategy an even 
more complex exercise. Although it is always possible for potential partners to draw up a contract to clarify ownership issues before they embark on a research project, there will always be grey areas that might ultimately lead to conflict. And exactly who are the partners concerned? A finding crucial to the planned research project could perhaps have been made in the course of an earlier project by researchers who might subsequently feel entitled to rights to the results of the co-operation envisaged with other partners, and so on.

The multitude of piffalls inherent in an international patent system cannot but raise misgivings among potential partners, if not actively discourage them from participating in projects whose outcome might now seem uncertain; indeed, it might ultimately lead to conflicts that could delay the application of results. At any event, it is certain to make the management of collaborative projects even more complex and costly.

\section{A System in Crisis?}

A patent would simply be no more than one of many instruments in the strategy of firms seeking to capitalise on, and protect, their inventions were it not for the fact that it has such a high transactional value. A patent can be wholly or partially sold, it can be licensed under a wide variety of conditions and it can be a decisive asset that will secure new partnerships. Patents are also viewed by some firms as a means of making profits. As a result, there is now a genuine world market for patents. This market is some- times criticised by industry as a purely financial construct which encourages 'patent-prone' behaviour that is both costly and to some extent detached from technological and economic realities.

Yet at the same time these technological and economic realities are evolving swiftly. The pace of technical progress is rising rapidly in many branches to the point where inventions are becoming obsolete well before the end of the 20-year period of protection afforded by patents. Moreover, by increasing the size of markets, which can now target more or less any product, globalisation is increasing the potential profitability of developing, either through reverse engineering or by means of other approaches, alternative solutions to compete with given patents. As a result, the dissemination of strategic knowledge through patent applications is perceived as an increasingly hazardous exercise. despite the protection afforded by patents. It is perhaps for this reason that a large number of firms - most operating in many sectors, as a number of studies would seem to show ${ }^{6}$ - prefer to protect their inventions by keeping them secret rather than by filing for a patent. This is a very difficult decision for SMEs, which now hope to globalise their activities through the new information infrastructures. Yet SMEs are a particularly vulnerable category of firms in that they practically never have the financial resources necessary to defend their patents when the latter are disregarded or circumvented by their principal competitors

Most firms are still primarily targeting local or national markets. And yet even if they are not actively seeking to internationalise their activities, they will gradually find themselves facing direct and increasingly forceful global competition.

As a result, the protection that patents are supposed to provide will become increasingly tenuous unless the inventor has the requisite financial resources to enforce his rights. Will patents be able to continue to fulfil their historical role as incentives for innovation? This question merits careful reflection at a time when firms, to protect their technological capital, are developing new strategies based on the control of strategic patents in certain sectors, the sealingoff of markets and widespread recourse to private standards,

Globalisation now calls with increasing urgency for efforts to harmonise patent systems so as to simplify the management of inventions, reduce the cost of patents and increase the effectiveness of such protection while at the same time safeguarding competition and the ability of the weakest participants to enforce their rights. How far should one go, and how should one pursue the reconciliation of what may ultimately be conflicting demands? Reform, indeed, is required, and that is what the international bodies are currently seeking to achieve, although each country will undoubtedly attempt to determine the freedom it intends to maintain according to its own traditions, resources, industrial fabric and system of innovation.

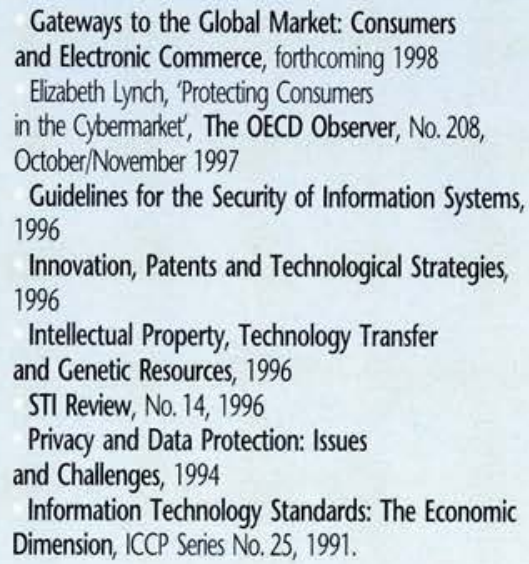

Gateways to the Global Market: Consumers and Electronic Commerce, forthcoming 1998 Elizabeth Lynch, 'Protecting Consumers in the Cybermarket', The OECD Observer, №. 208, October/November 1997 Guidelines for the Security of Information Systems, 1996 Innovation, Patents and Technological Strategies, 1996

Intellectual Property, Technology Transfer and Genetic Resources, 1996

STI Review, No. 14, 1996

Privacy and Data Protection: Issues and Challenges, 1994

Information Technology Standards: The Economic Dimension, ICCP Series No. 25, 1991.

OECD BIBLIOGRAPHY 


\section{The Agro-Food}

$\mathrm{E}$ nterprises in the agro-food sector have to face rapidly changing consumer preferences and habits: as their basic food requirements become fulfilled, consumers value a more varied and more sophisticated diet. In the United States a decade of new food products entering the market, in rising numbers each year, culminated in a record 17,000 in 1995. This demand for diversity means, of course, that consumers are becoming less attached to any given product or brand. Meanwhile, widening income gaps are leading to sharper differences in modes of consumption, as is reflected by the success of generic products and 'hard discount' stores.

Over the next 20 years these tendencies will be compounded by the effects of major demographic and social trends. Throughout the OECD countries, the population will age rapidly as the baby-boom generation grows older. Female participation in the workforce should continue to increase, and family size will shrink. These trends might lead consumers to adopt time-efficient ways of eating by using more convenience food and pre-cooked products, and food-delivery services and catering should grow. Furthermore, the recent spate of health scares connected with food (bovine spongiform encephalitis, salmonella, and so on) may remain in the public mind for a long time. In future consumers might

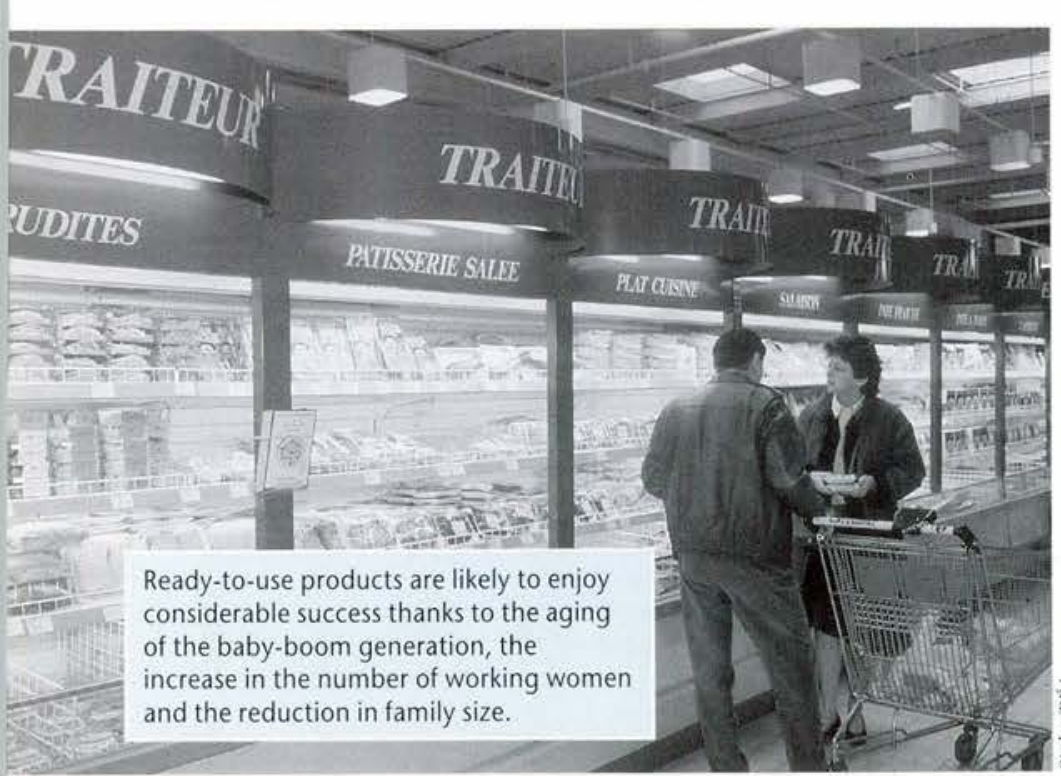
techniques. ${ }^{1}$

The agro-food sector has experienced radical change in the $O E C D$ countries over the past ten years. Although food consumption is falling as a share of GDP - in the United Kingdom and in Italy, for instance, it fell from 16\% in 1984 to $12 \%$ in 1994 - the supply of products is developing constantly, above all through advances in transport and storage techniques. At all stages in the sector (production, processing, trade), firms are becoming larger and are reshaping their relationships with one another. These are only the first results of far-reaching changes which are likely to intensify over the next few years in consumer expectations, market size, policy and production

request more information on the origin of products or on certain specific characteristics according to current concerns. Produce from organic farming should benefit from these trends, although high prices (on average 30-50\% above the equivalent non-organic produce) are likely to keep its market share small.

The second major factor of change will be the globalisation of agro-food markets. Sustained population growth, urbanisation and changing diets brought about by higher standards of living mean that food consumption should gather pace during the next few years in many developing countries in Latin America and Asia. Forecasts from the International Food Policy Research Institute suggest that meat demand in China should rise by $85 \%$ over the next 20 years and cereal demand by $30 \% .^{2}$ Some observers even believe that pressure on world agricultural production from some developing countries could trigger food shortages and a general surge in prices. The general opinion is nonetheless that the growth potential for the global supply of food is more than adequate to meet booming demand and that any regional shortages could be resolved through trade. On balance, some developing countries will probably become major importers of agro-food products, especially red meat and some processed product ${ }^{3}$ by the beginning of the next century. Agro-food enterprises based in $\mathrm{OECD}$ countries will therefore acquire large outlets for their products, investments and expertise.

The ensuing expansion in trade and international investment will probably be backed by the policies conducted in most countries. In the OECD area as a whole, agricultural policy has been reformed (or is about to be) so as to leave more room for market mechanisms. The next round of international trade negotiations under the World Trade Organisation (WTO) and the Multilateral Agreement on Investment (MAI)

Reza Lahidii is an economist at the Advisory Unit in the Private Office of the Secretary-General of the OECD. E-mail: reza.lahidji@oecd.org 


\section{Sector}

\section{in}
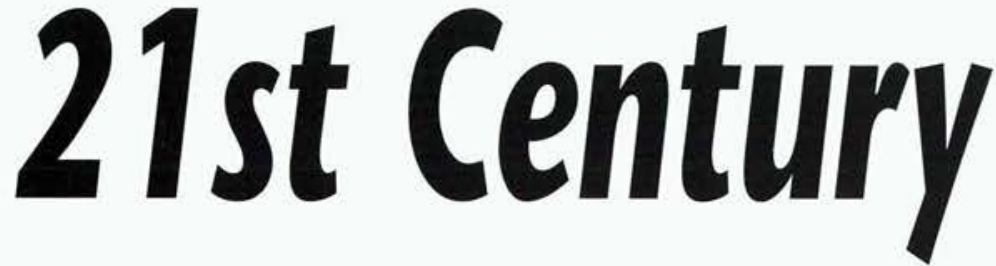

under preparation at the OECD should lead to further liberalisation of trade in goods and capital, especially in the agro-food sector, which in most countries is still among the most heavily protected sectors.

The third major factor of change will be technical. The food market in OECD countries has already been revolutionised over the past 15 years with the development of new techniques for cooking, packaging, transport and storage. Seasonal fresh produce is now available almost all year round. Supermarket convenience food and microwave cooking are commonplace. The next major changes will concern two activities: biotechnology and information techniques.

The scope for the application of biotechnology for the next 20 years is tremendous. It includes, among other things: improved product quality (taste, preservation and so on); the adaptation of plants to difficult conditions, higher crop yields through increased nitrogen fixation, resistance to disease and pests (parasites, insects) and pesticide tolerance; biodegradability of fertilisers and pesticides; faster and more reliable diagnosis of animal health and more efficient vaccines; the ability to identify a product formally throughout the agro-food production chain ('traceability'); new conversion techniques for industrial organisms.

1. This article follous a conference of the OECD Forum for the Future on the theme The agro-food sector on the thresbold of the 21st century. The proceedings of the conference are presented in The Future of Food: Long-term Prospects for the Agro-food Sector: $O E C D$ Publications, Paris, 1998.

2. Per Pinstrup Andersen, Major Uncertainties and Risks Affecting Long-term Food Supply and Demand; in The Future of Food: Long-term Prospects for the Agrofood Sector; op. cit.

3. Ferdinand Kuba 'Can China Achieve Self-sufficienoy in Food?' The OECD Observer No. 206, June July 1997 Pierre Charlebots and Josef Schmidhuber, Agricullural Trends and Issues to 2001, The OECD Observer: No. 205. April May 1997; Barrie Stevens, China Enter the 21st Century; The OECD Observer, No. 201, August September 1996.
This progress will be made on such a scale that both agriculture and the processing industry will enter a new 'green revolution'. By consuming lower quantities of chemical products, agriculture will gain substantial potential for growth and simultaneously become more environment-friendly. Meanwhile, more efficient techniques for control and processing will be implemented 'downstream'. Of course, there will still be a number of uncertainties to be resolved, the possible perverse effects on the environment and human health in particular. Genetic modification of plants might lead to the creation of dominant varieties and weaken the world's 'genetic heritage'. There might also be risks of dissemination in nature: for instance, a gene developed in a crop to develop resistance to herbicides might be transmitted to wild species.
From the economic point of view, the size of some organisations upstream of the agro-food chain, in biotechnological research (fertiliser producers, and so on), might create dominant positions that could damage competition. Finally, because of the real or assumed risks and ethical issues entailed, biotechnology faces prejudicial public opinion in many countries, especially in Europe. Mass rejection of these techniques by governments or large numbers of consumers might jeopardise their development.

The advent of the information society will also obviously have a major impact on the agrofood sector. First, huge amounts of statistics on purchases and consumer profiles will be collected and analysed. They will be used to define market segments more precisely, to identify niches and to allow early detection of new

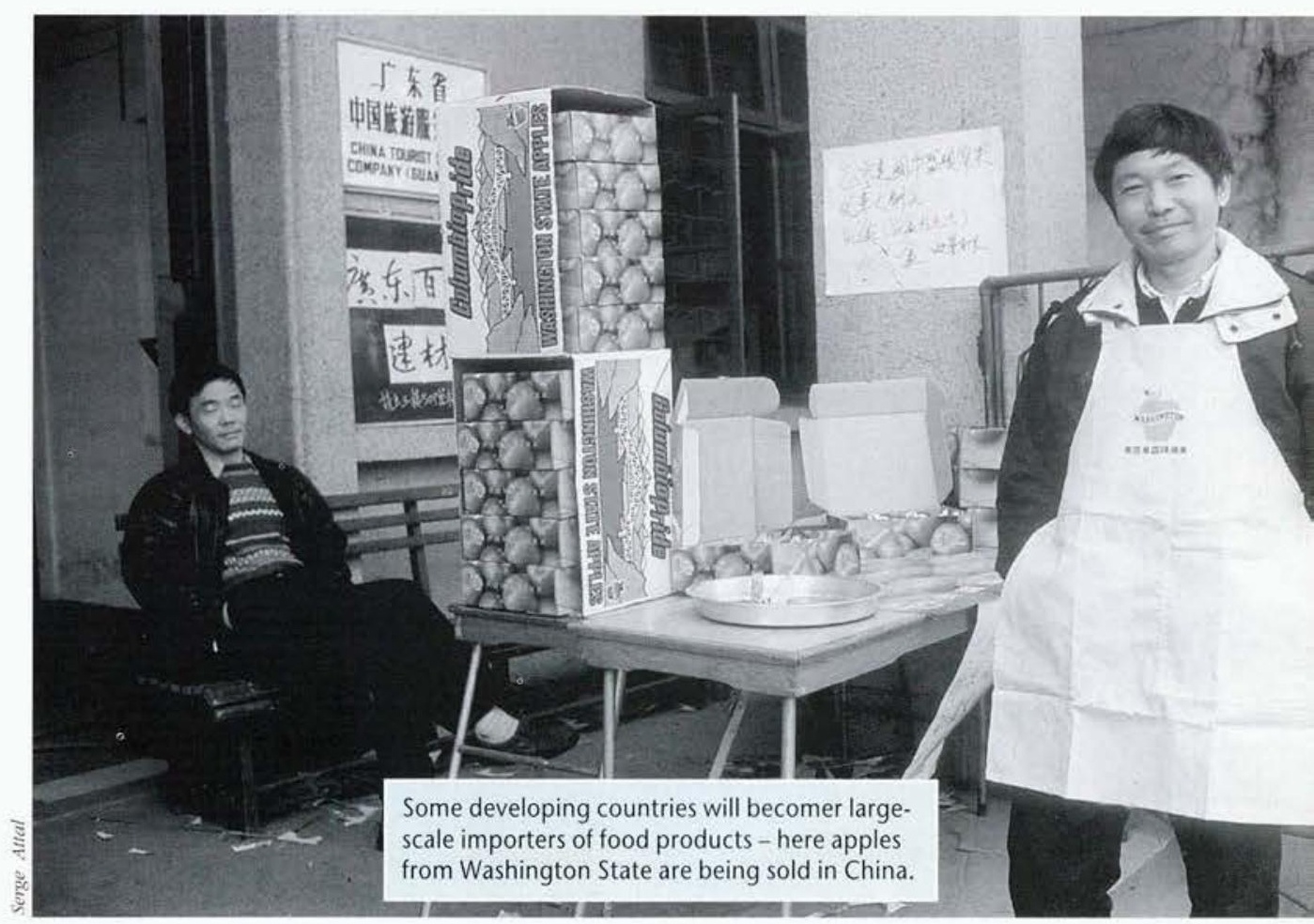




\section{The Agro-Food Sector in the 21st Century}

consumer trends. Such information can be transmitted upstream of the production chain in order to supply small-scale markets more reliably with shorter response times and lower costs. Simultaneously, the agro-food industry will be able to disseminate product information widely through computer networks such as the Internet and, where appropriate, sell products on-line with substantial savings in distribution costs. It is now estimated that electronic commerce and teleshopping could absorb $15 \%$ of the sales of agrofood products by 2010 .

\section{New Organisation}

Over the next few years, trends in OECD markets, globalisation and the emergence of new technologies are likely to shake up the environment in which agro-food firms operate. Increasingly sophisticated processes and the growing impact of information collection and analysis, research and development and communications should lead to higher fixed costs at all stages in the sector. More market segmentation will mean that firms will also have to narrow down their production methods and field of expertise, and such increased specialisation would leave them ill-placed in the event of a downturn in activity. Since demand for a specific product or brand might be highly volatile, specialist firms will run considerable risks. The parallel rise in fixed costs and risks very probably portend an increase in critical size. The process of concentration observed in the past twenty years in distribution, the food industry and, in some countries, in agriculture is therefore likely to continue, even gather pace.

One of the main features of the future organisation of the agro-food sector may be the role of vertical relationships. In OECD countries, markets should be divided into many different segments, which is bound to strengthen links between the various stages of production. In order, for instance, to supply a precise variety of

4. David Blandford and Linda Fulponi, Flectronic Markets in the Agro-food Sector; The OECD Observer. No. 208, October/Notember 1997. fruit that consumers seem to favour, a distribution chain will opt for safer continuous links with one or more specialised producers rather than uncertain purchases on the open market. And, using biotechnology, farmers will be able to produce the fruit variety required with constant quality. Vertical co-ordination with downstream firms will ensure outlets and, possibly, cover against risks arising from variation in price. Product traceability will also enable distributors or processors to check at all times that the fruit does indeed show the desired characteristics. Vertical relationships could also be used to send precise information promptly, making product supply more responsive to changes in demand. By reducing market size and generating new risks, segmentation thus leads naturally to increased vertical co-ordination.

This co-ordination will probably take on many different forms, from production contracts to strategic alliances and integration. Where there is little scope for product differentiation, as might be the case for most cereals, buyer/purchaser relationships should continue to be governed mainly by open markets. Conversely, vertical coordination could continue to grow on markets where it is already relatively well developed, as in fruit and vegetables, because of increasingly finer distinctions between product characteristics.

Whereas in theory vertical co-ordination should benefit all parties, in practice it might modify relationships in the agro-food sector to the benefit of distribution and to the detriment of farmers. In a sector where information about demand is likely to become the strongest factor. proximity to consumers might prove a decisive asset for distribution firms, which would be obvious candidates for organising vertical relationships and channelling production decisions, and would therefore have the means to inflect the distribution of risk and profit in their favour.

Current changes will also doubtless reveal winners and losers within each activity. For instance, the most enterprising farmers might find interesting opportunities through differentiation and production under contract. Conversely, more traditional farmers operating on markets for undifferentiated commodities might face a darker future. The agro-food sector as a whole will offer more attractive opportunities and higher risks. The most successful enterprises will be those which can build links upstream and downstream, establish a reputation of brand quality and innovate constantly. Their main asset will be human capital, to be mobilised in order to build up real market power.

Within the next 20 years, the food market should therefore be dominated by large groups with global strategies. With declining subsidies and protection, these enterprises will be able to organise purchasing, production and product marketing world-wide by using the comparative advantages of individual countries. Their decisions to locate activities in a given country will depend not only on its natural resources but also on factors such as domestic market size, the industrial and marketing fabric and infrastructure quality. Horizontal and vertical concentration of enterprises may therefore be accompanied by a geographical concentration of activities and globalisation through the clustering of production sites.

\section{Challenges for Government}

These changes will bring new challenges in regulation policy. Most OECD countries today are faced with the necessity of modernising and liberalising agriculture while taking into account its non-economic roles, especially in the environment and the planning of land-use. Measures intended for agriculture should be reassessed as to their costs and benefits and co-ordinated as part of a coherent policy, market-oriented and aiming to integrate agriculture into domestic and international economic mechanisms. That requires the progressive replacement of the policy of general price support by one of direct transfers to farmers, and that public bodies no longer introduce distortions into the market-place by acting as buyers of last resort. The dependence of farmers on the food industry might then increase and the differences between them widen. Government action might turn to new fields: the development of insurance mechanisms 


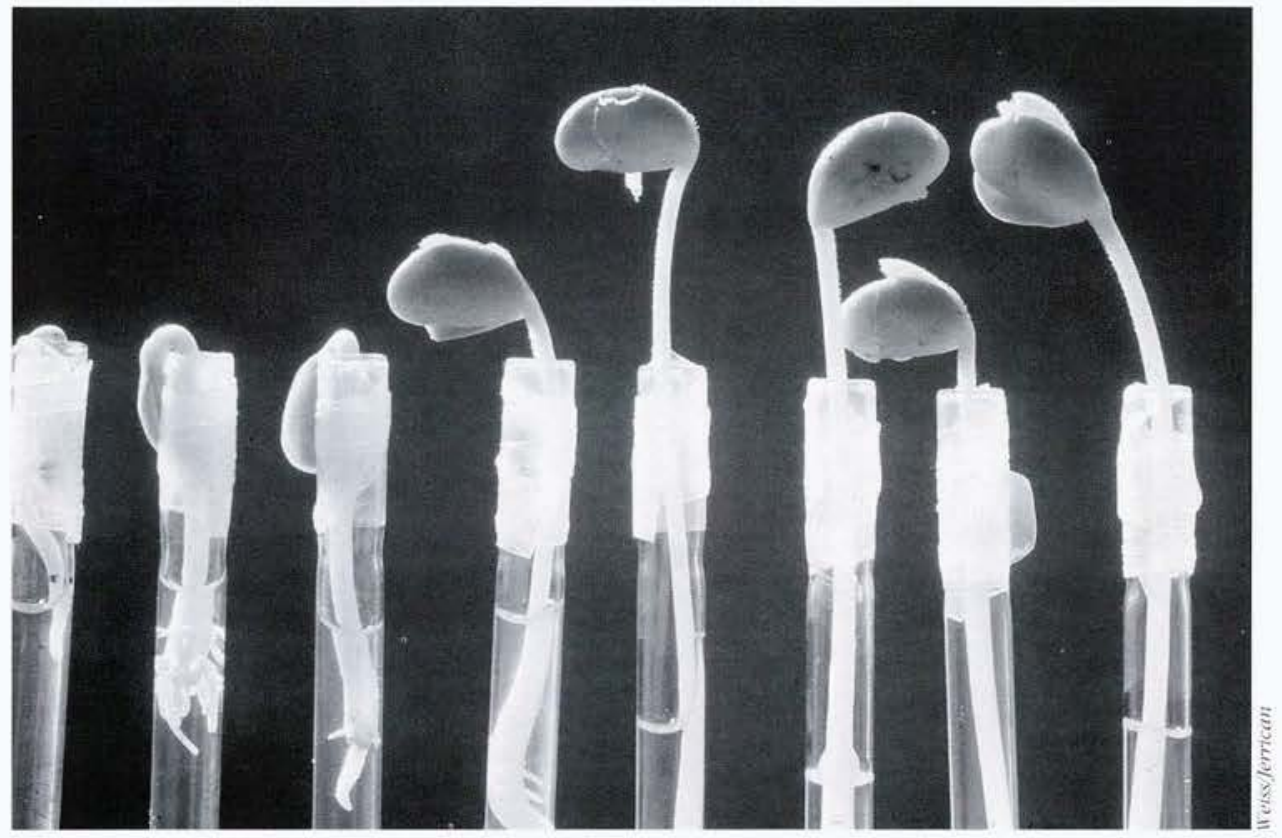

The likely scale on which biotechnology will be applied in twenty years' time will lead both agriculture and the food-processing industry into a new 'green revolution'. lation. For instance, the ethical issues arising from biotechnology or health risks might reveal farreaching differences between countries, even within the OECD. As a rule, any excessive or insufficient regulation in a single country could have consequences reaching well beyond its frontiers. OECD countries in particular will doubtless face a difficult choice between laying down high national standards and attempting to reach international harmonisation of standards (or the generalisation of mutual recognition agreements). Since differences between countries might result from opportunist or protective behaviour as well as from truly divergent objectives, these issues will have to be addressed in a multilateral context that is favourable to trade and investment, respectful of countries' individual circumstances and based wherever possible on scientific references. and of the means for farmers to move into higher value-added production, incentives for cooperatives to adjust so as to continue to support the negotiating power of farmers, the implementation of incentive schemes to help the environment.

Competition policy will address the complex issues arising from horizontal and vertical concentration and from the potential anti-competitive behaviour that might ensue. Admittedly, vertical and horizontal concentration can be justified on grounds of efficiency (economies of scale, optimum risk- and information-management). Regulatory policy should therefore be based on precise analysis - and hence detailed statistics of enterprise behaviour. Furthermore, publishing such information might as such be an efficient means of countering anti-competitive behaviour. But in a sector where transactions might chiefly concern private contracts of a specific nature, the collection of information might become complicated. Traditional concepts and yardsticks such as average price might soon become obsolete. One of the tasks awaiting gov- ernment policy will therefore be to build a new framework of analysis and monitoring for the successive stages in the manufacturing of food products.

Problems of hygiene, health and consumer trust are also likely to loom large. Since trade in food products is likely to expand and food production to use increasingly sophisticated processes, checks to ensure that foods do not present any health risks might be more difficult than at present. It will be up to public opinion and government in OECD countries to determine the acceptable degree of risk for human nutrition and to establish the respective roles of state and market in its control and surveillance. The introduction of credible and operational labelling and standardisation schemes might become necessary to ensure that consumers have at least some information about the products they are offered.

\section{므}

Many agro-food issues have an essential international dimension which might make it necessary to introduce genuine multilateral regu-

\section{OECD BIBLIOGRAPHY}

The Future of Food: Long-term Prospects for the Agro-food Sector, 1998

David Blandford and Linda Fulponi, 'Electronic Markets in the Agro-food Sector', The OECD Observer, No. 208, October/November 1997

Agricultural Policies in China, 1997

Ferdinand Kuba, 'Can China Achieve Self-sufficiency

in Food?, The OECD Observer, №. 206, June//uly 1997

The Agricultural Outlook, 1997-2001, 1997

Pierre Charlebois and Josef Schmidhuber, 'Agricultural Trends and lssues to 2001', The OECD Observer, No. 205, April/May 1997

China in the 21st Century: Long-term Global Implications, 1996

Barrie Stevens, 'China Enters the 21st Century', The OECD Observer, No. 201, August/September 1996 The Agricultural Outlook - Trends and Issues to 2000,1996

Loek Boonekamp and Yves Cathelinaud, 'Agricultural Markets from Now to 2000', The OECD Observer, No. 199, April/May 1996. 


\section{Reconciling Agriculture and the Environment}

Wilfrid Legg and Michel Potier

Improving the environment and ensuring the sustainable use of resources in agriculture are both important policy objectives in OECD countries. There has been some improvement in environmental performance, partly as a result of reforms in agricultural policy, in environmental measures such as financial incentives and regulations concerning air, water and soil quality, and in changes in technology and farm practices. And farmers themselves can help improve the environment if they are faced with the signals that alert them to the environmental costs and benefits of their activities, and if they have the motivation and necessary resources. But progress towards such market-based policies is slow. ${ }^{l}$

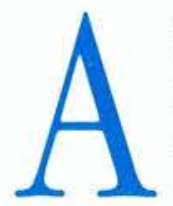

griculture affects the environment in a vast number of ways. It can help maintain rural landscapes, preserve wildlife habitat and biodiversity, and provide a carbon sink by trapping carbon which would otherwise pollute the atmosphere as carbon dioxide. It can assist in the sustainable management of water and soil resources, with a role in the prevention of landslides and flooding. It is an important element in regional development.

But agriculture can bring its problems, too. Excessive or inappropriate use of fertilisers, live-

\footnotetext{
Wilfrid Legg and Michel Potier are Heads of, respectively, the Division on Agricultural Policies and the Environment of the OECD Directorate for Agriculture, Fisheries and Food, and the Economics Division of the OECD Environment Directorate.

E-mail: agr.contact@oecd.org and

env.contact@oecd.org
}

stock manure and agro-chemicals can pollute and contaminate surface and groundwater. Farming can reduce the habitat available to wildlife - indeed, it has brought some species to the edge of extinction. It can lead to soil erosion, particularly when it brings environmentally sensitive land under cultivation. And the presence of malodorous livestock will hardly be a surprise to anyone who has travelled through the countryside.

Broader environmental developments, such as industrial pollution, acid rain and climate change, as well as a number of environmental measures and standards introduced both nationally and internationally (for instance, concerning the permitted nitrate content in drinking water) are in their turn having an impact on agriculture. They can influence the volume and intensity of agricultural production and its geographical location. Shifts in consumer pre-

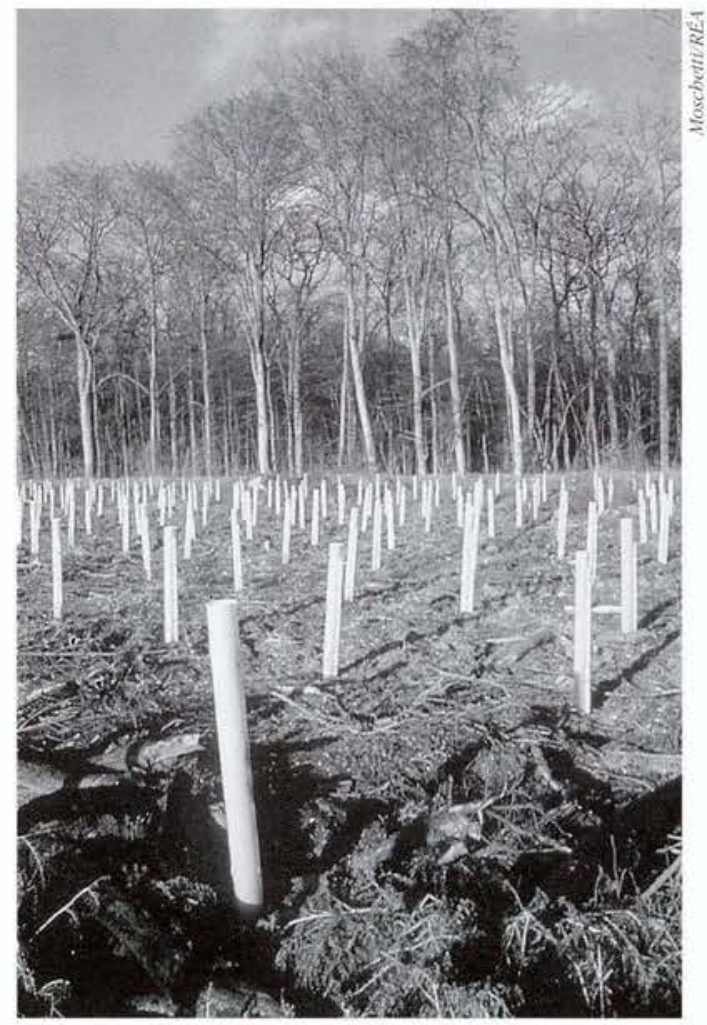

Agriculture can help maintain the countryside...

ferences towards 'environmentally friendly' agricultural and food products and changing technologies are likewise affecting farming practices. $^{2}$

In spite of the variety of environmental situations and agricultural systems across the OECD area, all countries apply policies aiming to minimise the risks to humans, natural habitats and biodiversity arising from the use of agricultural chemicals. They also aim to ensure sustainable agricultural production, and to limit global environmental impacts, not least by curbing emissions of greenhouse gases. 


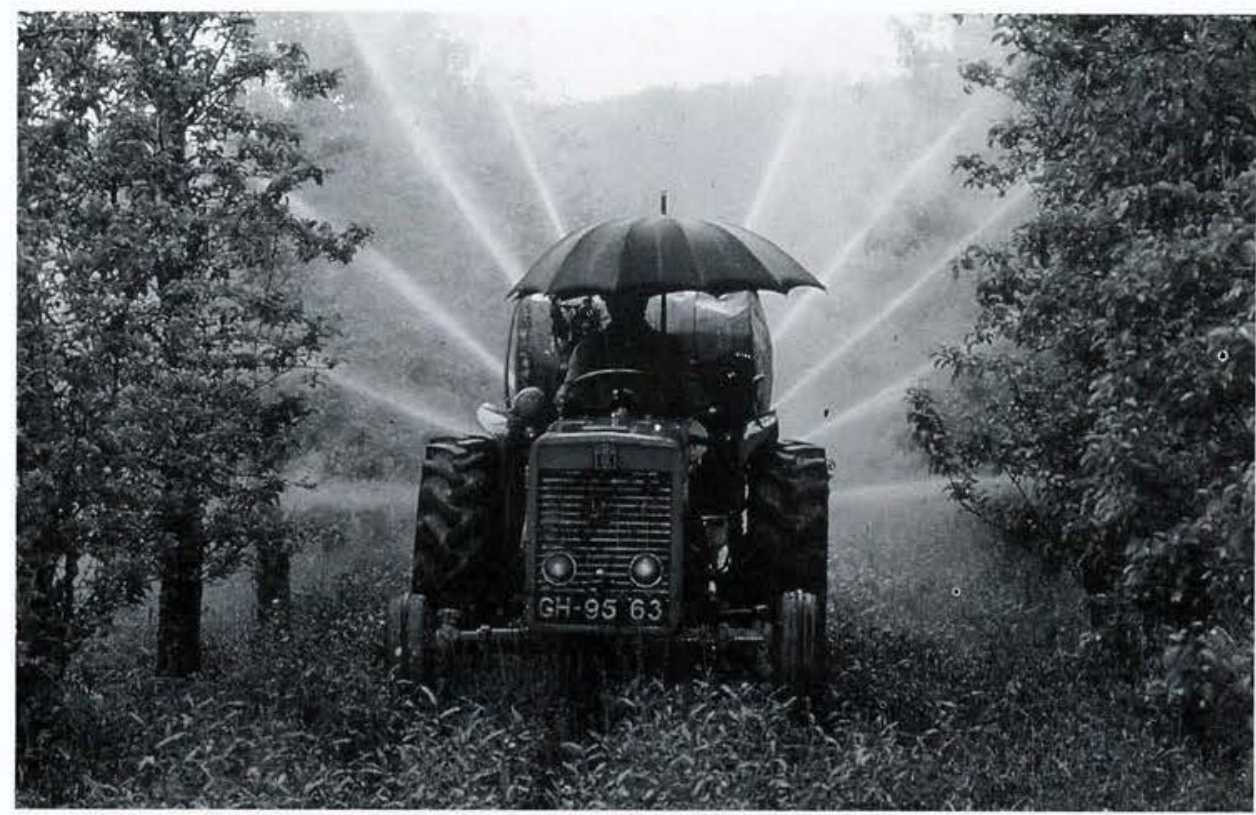

...but can also pollute groundwater through over-use of fertilisers.

The importance of different environmental issues nonetheless varies across countries. For example, where population density is high, as in many European countries, land and water resources are scarce and agriculture uses land intensively, problems such as livestock waste and nutrient run-off rank high on the policy agenda, and importance is given to the availability of and access to open spaces. In countries where land resources are abundant, with less population pressure and agricultural production systems that use land less intensively, such as Australia and the United States, soil erosion and land quality can be a primary concern.

For some countries environmental issues include biological and ecological aspects only. For others, they also embrace attention to landscape and cultural features, as well as rural development aspects of agriculture. Perceptions about 'nature conservation' vary, too. In some countries (the United States, for instance), the protection of wilderness is a major issue; others, such

\footnotetext{
1. Agriculture and the Environment: Issues and Policies, OECD Publications, Paris, fortbcoming 1998. 2. See $p$ p. 28-31.

3. Environmental Indicators for Agriculture, $O E C D$ Publications, Paris, 1997
}

as Japan, Korea and many of those in Europe, where agriculture has been an influence on the environment for centuries, concentrate on the preservation of man-made landscapes.

\section{Slow Progress}

Preliminary evidence suggests that in many OECD countries over the last decade there has been a reduction in the damage caused by the overuse of pesticides and nutrients, particularly damage to water (Figure 1). But there are exceptions to these trends, and the figures vary considerably across and within OECD countries. It is simply too early to draw firm conclusions on environmental performance in these two major areas. $^{3}$

There has also been some advance in the extent to which envi- ronmental costs and benefits enter into farmers production decisions. In some cases farmers are charged for any damage caused by farming. For instance, some farmers are made to bear their share of the costs of polluting rivers through the application of the Polluter-Pays Principle (PPP) in agriculture. Progress has been made, too, where farmers are able to capture the value of their 'environmental services' through rural tourism or higher prices for local products or 'environmentally friendly' agricultural production.

But farmers do not always bear the costs of the pollution they cause and are not always remunerated by the benefits they provide. In many cases, where markets are absent or policies encourage the use of agro-chemicals, farmers do not have to take pollution costs into account. In some countries they are given grants to cover the expenses of pollution abatement or do not pay a price for irrigation water that is compatible with sustainable water use. And although the OECD countries are committed to apply the PPP to account for the harmful environmental

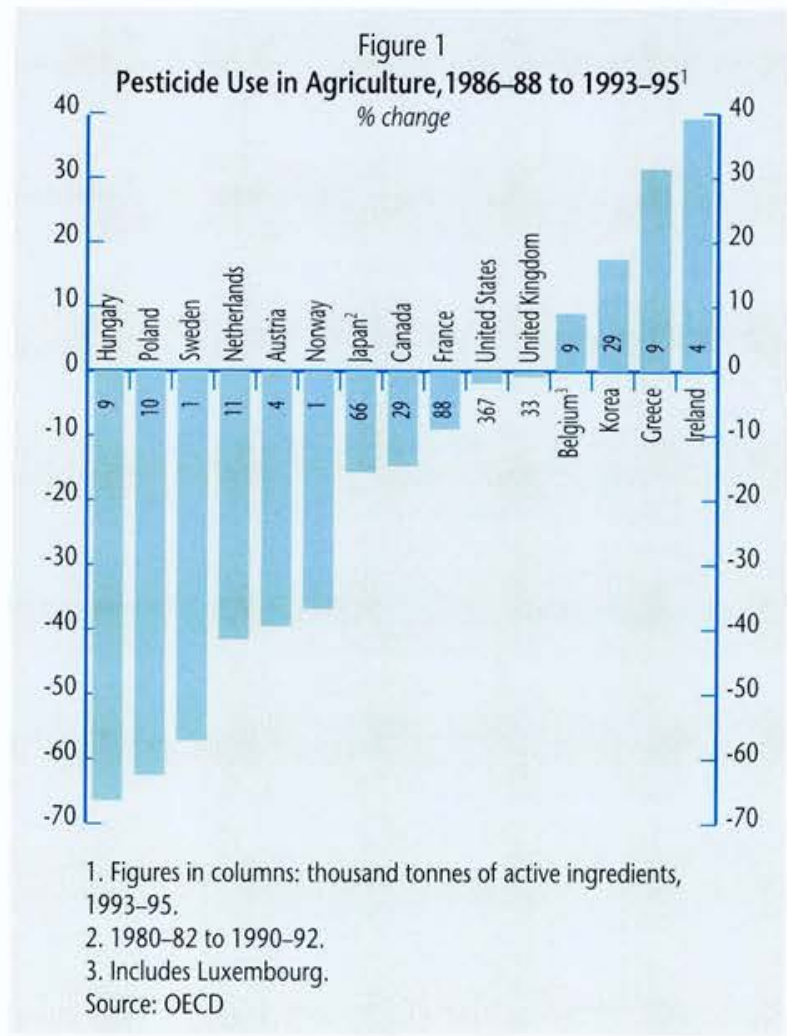




\section{Reconciling Agriculture and the Environment}

\section{FOCUS}

\section{The Environment and the Reform of Agricultural Policies}

Reductions in price support and input subsidies have in many cases led to less intensive forms of agricultural production, thus lowering the pressure on the environment, especially where support had in the past encouraged unsustainable practices.

In the crop sector, many farmers have responded to lower prices for their output and higher costs for their inputs by cutting down on the use of pesticides, fertilisers, machinery, and irrigation water; in the livestock sector, support reductions have led to smaller herds and lower stocking densities. As a result, nutrient surpluses and grazing pressure have declined and the risk of nutrient and pesticide run-off into surface water and leaching into groundwater has been reduced (Figures 1 and 3).

Policy reform has also slowed down or brought to a halt the conversion of wetlands, forests and natural grasslands to agricultural use, thus preserving substantial areas of natural ecosystems.

Where land susceptible to erosion has been afforested or its use shifted from cropping to grazing and forage production, the grass or tree cover established on this land has reduced erosion and helped restore degraded soils. And in other areas where agroecological conditions make production difficult, policy reform can bring the risk that land is abandoned. In some instances, of course, the land will simply revert back to nature; in others it may suffer degradation, causing a loss of wildlife habitat and biodiversity. The adverse effects of abandoning land are most likely to occur in areas with low-input farming systems that support a rich variety of flora and fauna as well as scenic landscapes, and in areas where agriculture contributes to land conservation, including landslide and flood prevention. effects of economic activities (not merely those arising from agriculture), it has not always been applied or fully enforced in agriculture.

To distinguish between the beneficial and harmful effects of agriculture requires a reference figure, or benchmark. Such a benchmark can be quantitative (for instance, parts per million of phosphate in drinking water) or qualitative (desirable characteristics of landscape, say). The identification and codification of 'good farming practices' can give guidance towards the achievement of such reference points. The reference point represents what is expected that farmers or landowners provide - at their own cost - in their role as 'stewards' of the countryside. If society demands environmental benefits from agriculture (such as the maintenance of sustainable farming practices, the provision of habitats for wildlife or the prevention of soil erosion in fragile mountain areas) above the reference point, society could be expected to remunerate farmers for providing them. ${ }^{+}$

\section{The Policy Effect}

Agricultural policy measures, especially those that encourage the production of specific commodities and the use of certain inputs, have increased farm production, encouraged farm practices that damage the environment, and led to the expansion of agriculture on to sensitive land. But they have also encouraged farming to continue in areas that might otherwise have been abandoned (Figure 2) and have sometimes given farmers sufficient remuneration for them to undertake land and water conservation or maintain landscapes in these areas. But since many agricultural policy measures are implemented nationally, whereas the environmental effects of
Figure 2

Land in Agricultural Use, $1973-75$ to 1993-95

$\%$ change

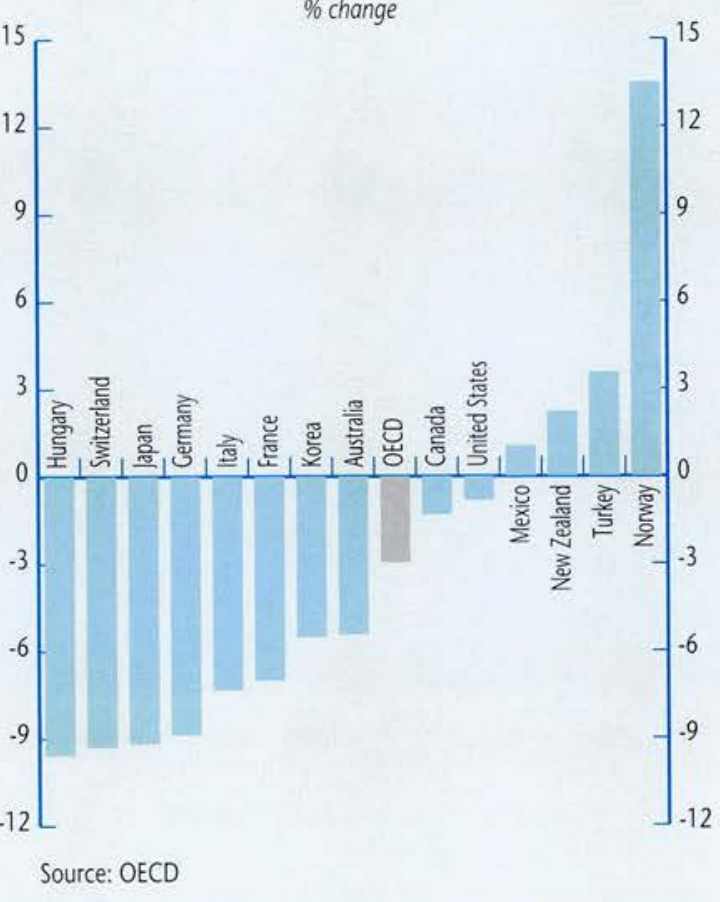

agriculture are local, they are not sufficiently targeted and tailored to specific environmental problems to be effective.

In a period of falling overall volumes of support to agriculture, there has been some shift away from price support towards policy measures that are less distortive of production and trade, allow more influence for market signals, and are more efficient in targeting particular problems. Such policy measures include direct income support as well as agri-environmental measures specifically designed to achieve environmental objectives. Over the last decade, market price support declined from $65 \%$ across the OECD area to $59 \%$ of total support in 1996 . That reduction has brought in some changes in the volume, composition and location of production, and in farming practices, although the effect on the environment as a whole will depend on differences in the natural-resource base, farmmanagement practices and the production mix (box, left). ${ }^{5}$ Two examples are the composition of livestock in New Zealand or changes in land- 
use in Austria, which have lowered some of the pressure on the environment.

But agricultural policy reform will have to be complemented with other measures. The volume of agricultural output that will arise under more market-oriented policies, and the farm practices that emerge, could in certain cases have an adverse impact on the environment. Although the reform of agricultural policy will alleviate some problems, others will persist and new ones could be created, especially in land use. To prevent degradation of the land used in (or withdrawn from) agriculture after reform, complementary policy measures may be required to enhance sustainable farming practices. Some countries have begun to use new types of agricultural policy measures to address the environmental and broader rural and structural adjustment issues, and more attention has been paid to sector-wide impacts. These new measures include:

\section{FOCUS}

\section{Agri-environmental Measures}

Many countries have implemented agrienvironmental measures to address specific environmental problems. Such measures are most effective when they have clear environmental objectives and respect certain operational conditions. In 1995 the United States spent an estimated $\$ 1.7$ billion for diverting 14.6 million hectares of land from crop production under the Conservation Reserve Program. Also in 1995, the European Union spent ECU 465 (\$608) million to co-finance measures for the protection of the environment and the maintenance of the countryside in its member states. In the same year the Japanese government provided $¥ 3.25$ billion ( $\$ 34.5$ million) in financial support for agricultural $R \& D$ aimed at improving the environment. In the financial year 1995/96 the Australian government spent nearly A\$80 (US\$59) million on the National Landcare Program.
- more tying of income support to environmental conditions ('cross-compliance')

- agri-environmental measures (box, below)

- charges and taxes

- regulations of fertiliser and pesticide use ${ }^{6}$

- research, information and extension services focused on sustainable farming practices

- co-operative solutions to address local environmental concerns, such as land care?

The new measures might offset some of the damage caused by high volumes of support, but at a higher cost if such support remains. To pay farmers for reducing the pollution created by policies continuing to encourage an excessive use of fertilisers can indeed be very costly. Any improvement of the environment involving the use of privately owned factors of production, which are considered to be providing services over and above what is provided through 'good farming practices, will be delivered in sufficient quantity only if they are appropriately remunerated. Agri-environmental payments are sometimes used in such cases, but they have to be cost-effective in achieving their objectives, and should not distort agricultural markets. There are a few simple rules to guide policy to this end. Payments have to be:

- transparent in their objectives and operation - targeted to ensure the provision of the benefits, which would otherwise not be provided above the recognised reference figure

- tailored to particular environmental situations, limited to cover the costs of providing the benefits desired, and accompanied by adequate advice and information

- monitored to ensure compliance and effective implementation

- evaluated as to their environmental effects, and adapted periodically to ensure that they provide the desired results at the lowest cost.
By improving the efficient allocation of resources, promoting economic growth and increasing welfare, trade liberalisation will also benefit the environment, again provided effective environmental policies are implemented. As agricultural trade becomes freer, agricultural production is likely to expand in some countries or regions and contract in others, which will change the pressure on the environment. Although it is difficult to predict precise changes, countries in which producers of commodities receive high

4. Environmental Benefits from Agriculture: Issues and Policies - The Helsinki Seminar: OECD Publications, Paris, 1997; Wilfrid Lege and Luis Portugal. How Agriculture Benefits the Enwironment' The OECD Observer: No. 205. April/May 1997.

5. The Environmental Effects of Reforming Agricultural Policies: A Preliminary Report OECD Publications, Parts, fortbcoming 1998 .

6.Agriculture, Pesticides and the Environment: Policy Options, OECD Publications, Paris, 1997.

7. Co-operative Approacbes to Sustainable Agriculture, OECD Publications, Paris, fortbcoming 1998: Ronald Steenblik. 'When Farmers Fend for the Enviromment, The OECD Observer: No. 203, December 1996/amuary 1997. 


\section{Reconciling Agriculture and the Environment}

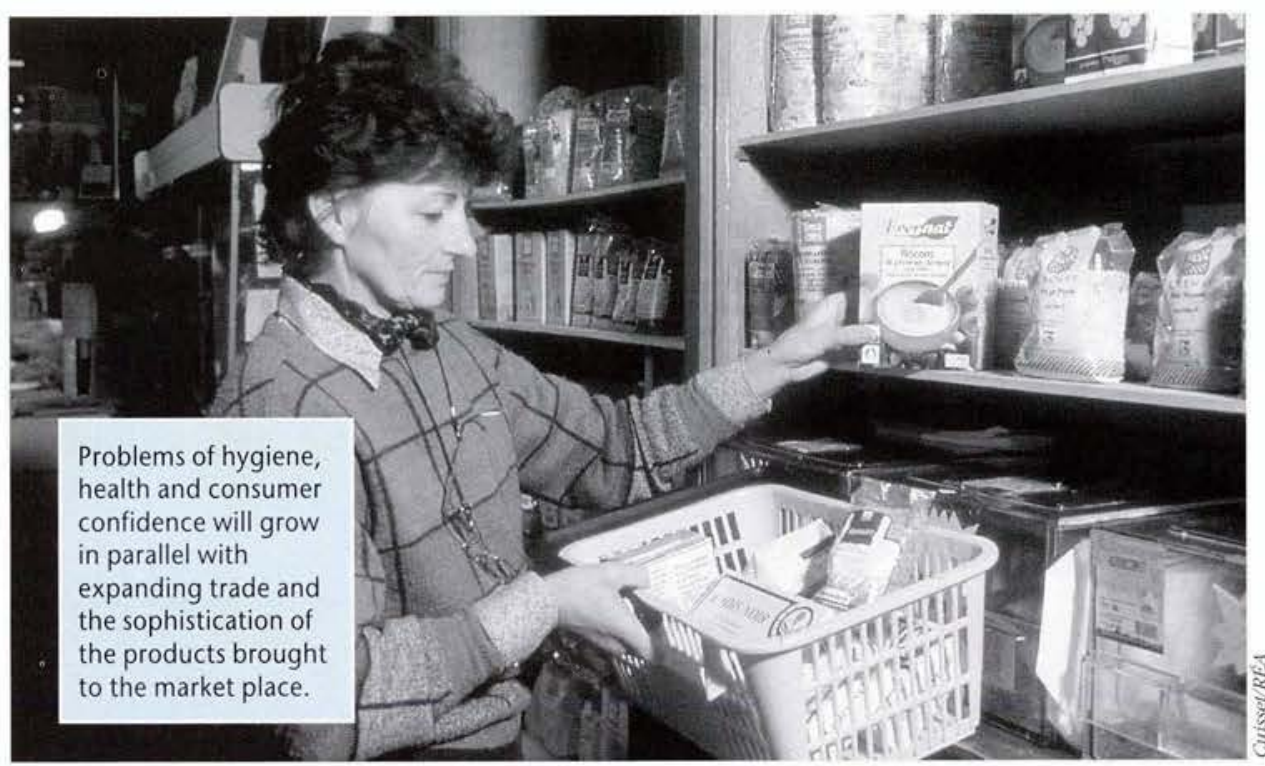

volumes of support through trade protection (such as many European countries, Japan and Korea) would produce less in a freer market environment. Countries with comparatively low degrees of protection (such as Australia or New Zealand) can be expected to expand production. The growth in trade may also result in more international traffic and possibly more pollution from fossil-fuel combustion, and an increased risk of importing pests and diseases. But appropriate accompanying policy measures, including those aimed at internalising environmental costs and benefits, together with a progressive elimination of domestic policies that encourage unsustainable farming practices, and the increased economic activity generated from trade liberalisation will facilitate environmental improvement as production moves to areas with comparative advantages in water and land resources and climatic conditions.

In order to assure that the full benefits of trade liberalisation are reaped and that unwanted environmental side-effects are prevented, targeted environmental measures will often be necessary to ensure that any environmental externalities generated by trade liberalisation are adequately reflected in farmers' production decisions.

\section{Which Measures?}

Often, farmers are little aware of the environmental costs and benefits of their activities, or of the practical possibilities for improving their environmental performance. Closer attention to the more effective application, provision and dissemination of knowledge - including the establishment of codes of good agricultural practices can help them to adopt sustainable farming methods and take account of how they affect the environment in their decisions.

More attention should be paid to exploring the potential of markets and innovative marketbased policy approaches to address environmental issues, and to putting a value on the environmental externalities involved in agriculture. A range of policy measures and approaches will be required to address such issues:

- information, advice and training programmes, complemented by research and development incentives, can be very effective in enhancing the general awareness of farmers of how they can cultivate their land in environmentally sustainable and financially viable ways

- regulatory measures may be appropriate where environmental damage from a specific practice (the illegal or careless uses of pesticides, for instance) could be severe and the resource loss irreversible, and where rapid results are required - economic instruments, such as incentive payments, taxes and charges, or transferable permits, may be appropriate where farming practices affect the environment in a way that can be taken into account by farmers

- cross-compliance measures (which work by making the eligibility for income support conditional upon farmers taking specific actions, such as ensuring identified environmental outcomes) may be effective where income support is still important, and where practicable and enforceable environmental conditions can be identified - co-operative approaches can be suitable for addressing specific local environmental issues, where farmers can apply their local expertise, and where collective action results in lower-cost solutions to environmental problems, such as in the Australian 'Landcare' groups.

The recognition is spreading that policy measures and approaches intended to improve the environmental performance of agriculture have to provide farmers with a set of consistent incentives. This new awareness will make the continuing process of policy reform more effective in reducing the harmful effects that agriculture, responding to the current framework of policies, is having on the environment. And aligning agricultural and environmental policies to remove conflicting goals will assist the long-term pursuit of sustainable development. -

\section{OECD BIBLIOGRAPHY}

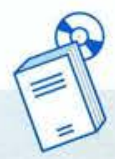

Agriculture and the Environment: Issues and Policies, forthcoming 1998

The Environmental Effects of Reforming Agricultural Policies: A Preliminary Report, forthcoming 1998 Sustainable Management of Water in Agriculture The Athens Workshop, forthcoming 1998

Co-operative Approaches to Sustainable Agriculture, forthcoming 1998

Environmental Indicators for Agriculture, 1997 Agriculture, Pesticides and the Environment: Policy Options, 1997 Environmental Benefits from Agriculture: Issues and Policies - The Helsinki Seminar, 1997

Wilfrid Legg and Luis Portugal, 'How Agriculture Benefits the Environment', The OECD Observer, NNo. 205, April/May 1997

Ronald Steenblik, When Farmers Fend

for the Environment', The OECD Observer, №. 203, December 1996//anuary 1997. 


\section{Fiscal Consolidation,}

\section{Growth and}

Robert Ford

The fiscal consolidation that most of the OECD countries have undergone over the past decade or so has brought traditional benefit systemsnot least for the unemployed-under pressure. At the same time, the distribution of incomes has been widening and, in some countries, poverty is on the increase. Reforms to incomeredistribution programmes are therefore likely to mean doing more with less. The governments of OECD countries will have to respect equity while maintaining efficient economies and, in particular, the incentives that will bring people back to work.

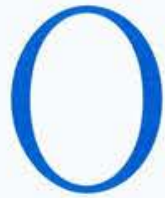

ver the past quarter-century the OECD countries have experienced rising ratios of debt to GDP; by 1996 for the OECD area as a whole government debt had reached over $70 \%$ of GDP (Table). This development can be attributed to two factors. There were chronic fiscal deficits, since governments were spending far more than they raised in taxes. And there were growing costs in servicing government debt, both because of the larger volumes of debt itself and the widespread increase in real interest rates in the late $1970 \mathrm{~s}$.

This pattern of deficits and expanding debtratios is at sharp variance with past experience of state finance in peace-time, one of declining debt-GDP ratios following build-ups in time of

Robert Ford is Head of the Public Economics Division in the OECD Economics Department.

E-mail: eco.contact@oecd.org
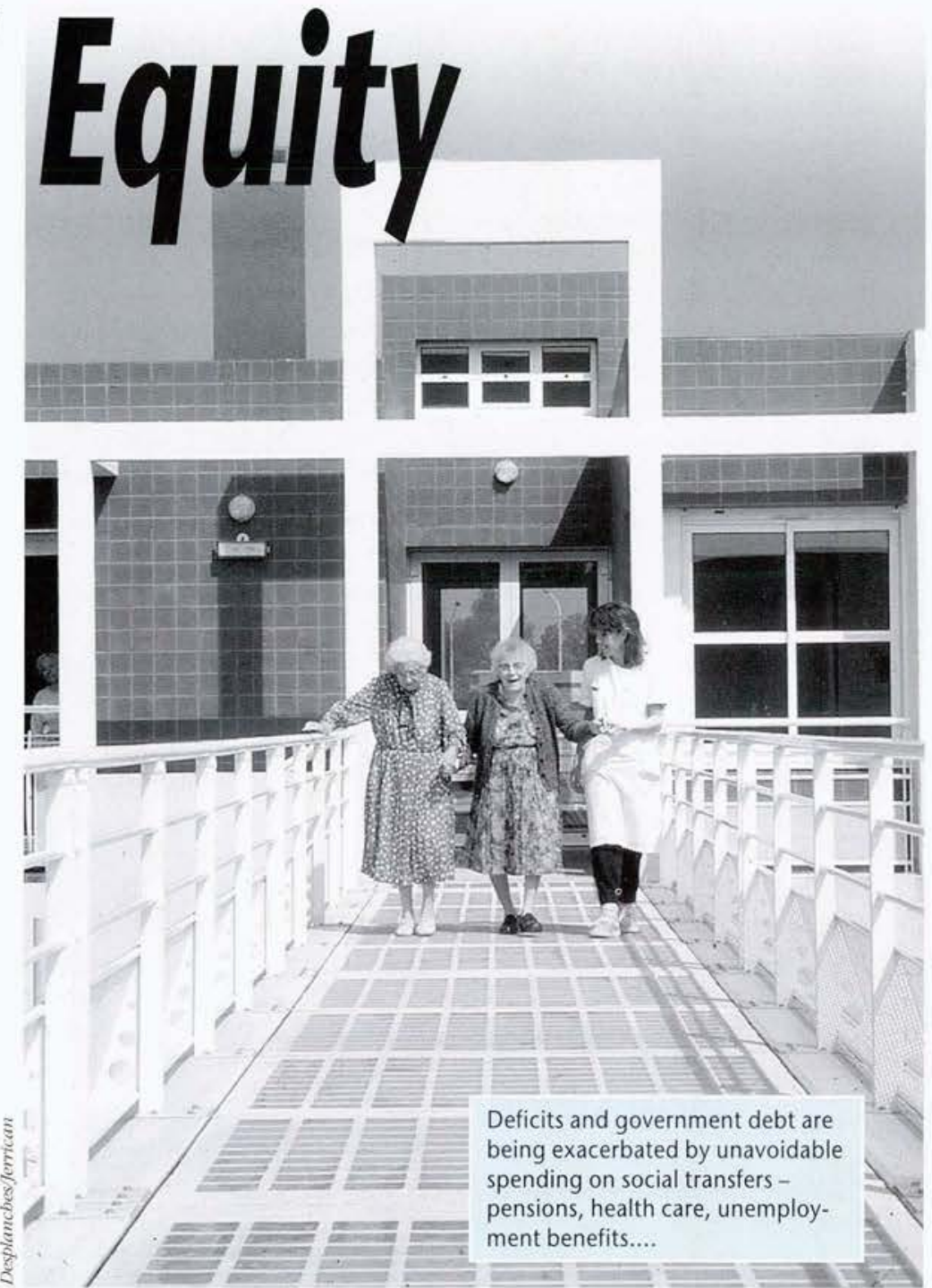

war. And it is not only deficits that have grown. In most OECD countries, since the 1970 s, both government spending and taxes have expanded as a share of GDP: by 1996 these averaged over 40 and $35 \%$ of GDP, respectively, for the OECD as a whole.

Trend increases in expenditure can usually be traced to transfer programmes, including health-care, pensions and, particularly in Europe (where the structural component of unemployment has risen), unemployment insurance and other programmes to support the incomes of the non-employed. Many such programmes were implemented, or substantially expanded, in the 1960 s and 70 s on the basis of favourable ex- pectations for economic growth and demographic developments that have not been realised.

On the tax side, the most important regularity is the growing burden of taxes on labour in many countries. To some extent, this shift reflects the fact that many of the expanding transfer programmes have been financed from earmarked payroll taxes. But it may also reflect a concern that high rates of capital taxation could reduce investment and thereby productivity. In many countries, especially in continental Europe. there has been a sizable increase in the 'wedge' between the wages that firms pay and what the workers receive, the result of higher taxes in 


\section{Fiscal Consolidation, Crowth and Equity}

general combined with the shift in their composition towards more reliance on taxes on labour. In conjunction with other labour-market imperfections, this wedge has contributed to high rates of structural unemployment.

In the light of these developments, there is almost universal agreement among policy-makers that the cuts in deficits were both necessary and healthy. There is now a consensus, moreover, that further fiscal consolidation is required in most OECD countries, a view reflected in official medium-term fiscal goals (box, p. 40). In the longer term - early in the next century in Japan, ${ }^{2}$ and in the following two decades elsewhere the dominant effect on fiscal outcomes in most countries will probably be population aging, which will put enormous demands on socialsecurity and health-care programmes just as the working population is stagnating, even shrinking, and thus cutting into the tax base. ${ }^{3}$ Meeting commitments on these budget lines will inevitably squeeze other types of public expenditure. although it will also force a re-thinking of the appropriate basis for entitlements to pensions and other transfers.

\section{Fiscal Probity, Social Strains?}

Against this fiscal backdrop, there have been growing concerns that economies are becoming less equitable and that as a result the social fabric is coming under strain. Although there are many ways of assessing equity and the degree of social cohesion, two developments stand out.

First, in many countries, principally several of those in continental Europe, unemployment rates have risen substantially and persistently,

1. Sucinbjörn Blondal and Stefano. Scarpetta, The OECD Johs Strategy under Scrutiny, and Peter Schuanse Activating the Inemployed: The OECD Observer No. 209, December 1997January 1998.

2. Randall S. Jones, Tapan - Population Aging: The OECD Observer No. 209. December 1997Jamuan 1998

3. Peter Hicks The Impact of Aging on Social Policy The OECD Observer; No. 203, December 1996/anuary 1997, and Lans Bovenberg and Anja van den Linden. Pension Policies and the Aging Society, The OECD Observer. No. 205, AprillMay 1997. particularly among the long-term out-of-work and the young and unskilled. As a result, there has been an increase in marginalisation, a more unequal distribution of market income and more pressure on transfers to support the living standards of the jobless.

Second, in some OECD countries, earnings and income inequalities have widened and the number of poor - defined relative to the mean or median national income - has risen. ${ }^{5}$ The causes of widening inequalities remain a matter of some debate, with the two leading candidates being technological change that has increased the demand for highly paid skilled labour and reduced the demand for the unskilled, and globalisation of trade and production that has increased competition between low-paid workers in developing countries and the unskilled in industrialised countries. ${ }^{6}$ The evidence now points to technological change as accounting for the bulk of the widening in earnings and income distributions. Other changes, such as the decline in unionisation and immigration, may also have exerted a measurable influence on the relative wages of the low-skilled in some countries, the United States in particular.

\section{Table}

Trends in Debt, Expenditures and Taxes in 22 OECD Countries, 1970-96

$\%$ of CDP

\begin{tabular}{|c|c|c|c|c|c|c|c|c|c|}
\hline & \multicolumn{3}{|c|}{ Gross Debt } & \multicolumn{3}{|c|}{ Expenditures } & \multicolumn{3}{|c|}{ Taxes } \\
\hline & 1970 & 1980 & 1996 & 1970 & 1980 & 1996 & 1970 & 1980 & 1996 \\
\hline United States & 41.5 & 37.0 & 63.9 & 30.0 & 31.4 & 33.3 & 28.9 & 30.0 & 31.7 \\
\hline lapan & 11.5 & 51.2 & 86.4 & 19.0 & 32.0 & 36.2 & 19.7 & 25.6 & 29.0 \\
\hline Germany & 18.1 & 31.1 & 64.9 & 38.3 & 47.9 & 49.0 & 37.2 & 43.9 & 44.1 \\
\hline France & .. & 30.9 & 63.0 & 38.5 & 46.1 & 54.5 & 37.4 & 43.6 & 47.6 \\
\hline Italy & 38.1 & 58.1 & 125.2 & 33.0 & 42.1 & 52.9 & 27.9 & 32.4 & 44.8 \\
\hline United Kingdom & 77.1 & 54.0 & 61.3 & 36.7 & 43.0 & 41.9 & 35.6 & 35.1 & 35.5 \\
\hline Canada & 52.8 & 44.0 & 100.3 & 33.5 & 38.8 & 44.7 & 31.3 & 30.3 & 37.2 \\
\hline G7 & 36.0 & 41.6 & 73.8 & 30.3 & 36.2 & 39.6 & 29.2 & 32.2 & 35.2 \\
\hline Australia & .. & .. & 43.8 & .. & 31.4 & 36.6 & .. & 27.7 & 31.6 \\
\hline Austria & 19.4 & 37.7 & 69.8 & 38.5 & 48.1 & 51.7 & 38.5 & 44.5 & 46.1 \\
\hline Belgium & 63.7 & 78.2 & 130.1 & 41.8 & 57.8 & 54.3 & 38.3 & 47.4 & 49.9 \\
\hline Denmark & .. & 44.7 & 74.8 & .. & 56.2 & 61.5 & 40.4 & 48.1 & 54.4 \\
\hline Finland & 15.9 & 14.1 & 61.4 & 30.0 & 38.1 & 57.4 & 33.0 & 38.4 & 50.0 \\
\hline Greece & 17.6 & 22.9 & 111.9 & .. & 30.4 & 44.7 & 21.6 & 25.1 & 33.9 \\
\hline Iceland & .. & 25.2 & 57.6 & .. & 32.5 & 38.1 & .. & 31.8 & 33.5 \\
\hline Ireland & .. & 72.7 & 76.5 &. & 48.2 & 37.6 & .. & 33.1 & 35.3 \\
\hline Korea & 23.5 & 16.0 & 2.7 &. & 19.3 & 21.2 & .. & 18.7 & 24.3 \\
\hline Netherlands & 51.5 & 46.9 & 78.5 & 41.3 & 55.8 & 49.9 & 37.7 & 45.9 & 44.8 \\
\hline New Zealand & .. & .. & .. & .. & .. & 47.1 & .. & .. & 47.3 \\
\hline Norway & 42.9 & 47.6 & 40.1 & 36.7 & 43.8 & 45.5 & 37.3 & 45.8 & 44.7 \\
\hline Portugal & 19.0 & 32.8 & 67.6 & 19.8 & 23.6 & 47.0 & 20.9 & 27.9 & 41.3 \\
\hline Spain & .. & 18.3 & 74.6 & 21.6 & 32.2 & 43.3 & 20.9 & 29.1 & 37.6 \\
\hline Sweden & 30.5 & 44.3 & 79.8 & 42.8 & 60.1 & 64.7 & 43.4 & 50.6 & 55.6 \\
\hline OECD & 35.7 & 40.2 & 72.2 & 30.5 & 36.5 & 40.3 & 29.4 & 32.4 & 35.9 \\
\hline
\end{tabular}


It is difficult to disentangle these factors, even in principle. For example, increases in international trade reflect both policy changes, including the decline in trade barriers under GATT and the WTO, and technological innovations which have reduced transport costs. And pressures of trade may be a factor in biasing technological change by encouraging the replacement of unskilled labour by machinery or, in the aggregate, by inducing firms in OECD countries to abandon the production of goods that compete most directly with those produced in developing countries, such as textiles and steel, and to produce instead skill-intensive products, such as financial services.

Irrespective of the underlying causes, this phenomenon threatens to marginalise workers trapped in poorly paid and insecure employment, perhaps giving rise to a class of 'working poor', with low incomes and relatively slim chances of improvement. A central issue in assessing how serious this problem might be is the degree of mobility within the earnings distribution: if people are highly mobile, then 'pointin-time' distributional measures would considerably overstate inequalities in incomes and opportunities over individuals' entire lives. Although not enough is known about mobility (largely because the data on the subject are very weak), it would appear that there is a considerable degree of movement out of the low-earnings group - but that a substantial amount of point-in-time inequality can nonetheless persist for several years?

\section{Which Trade-offs?}

The OECD Jobs Strategy and subsequent analysis laid out a broad-based and comprehensive strategy to durably reduce unemployment. Although it takes time to take effect, beginning in the 1980s a few countries - Ireland, the Netherlands, New Zealand and the United Kingdom $^{8}$ - which had introduced labour-market reforms along these lines, were able to reduce their unemployment rates and raise employment. Australia and Canada have launched reforms in the

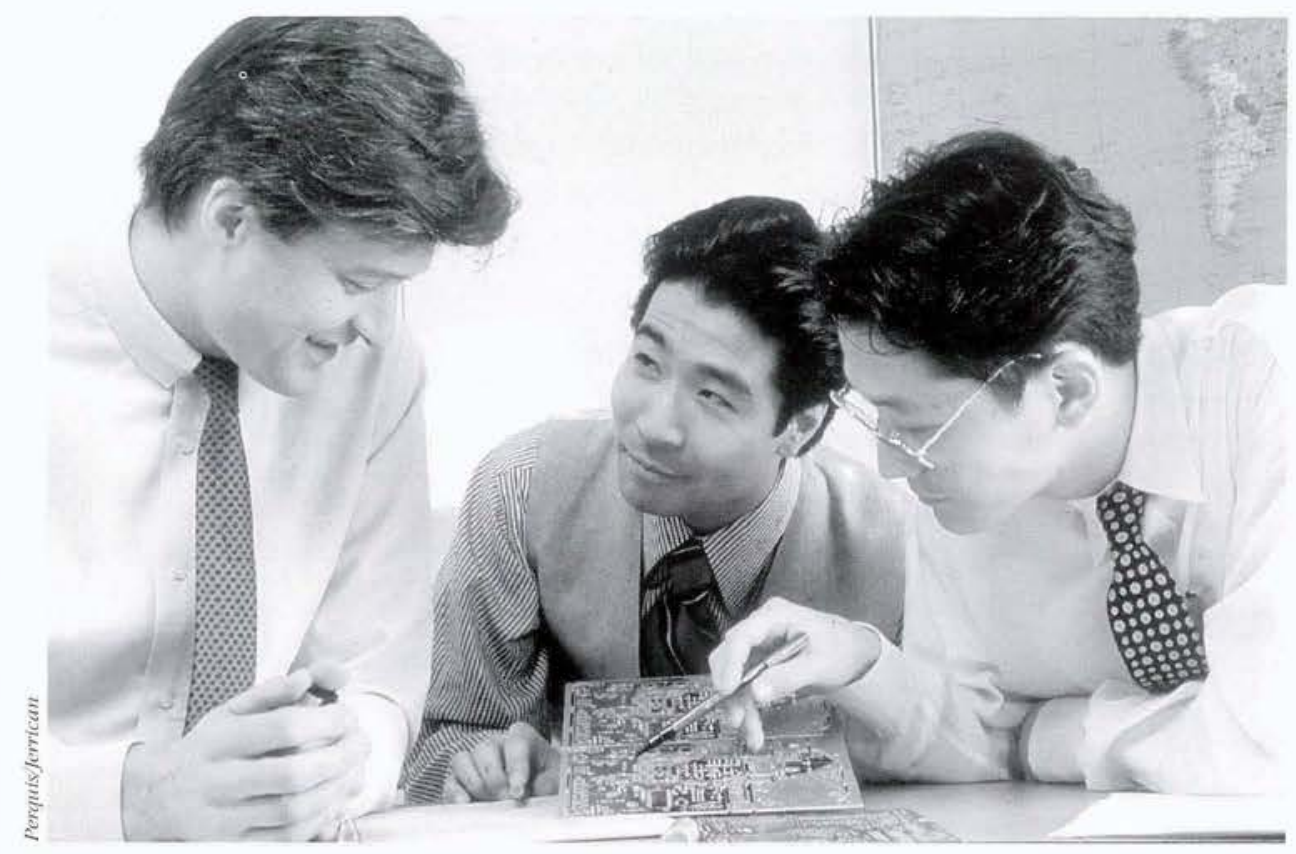

Technological progress, which has increased the demand for highly qualified workers and reduced that for the low-skilled, has reinforced inequalities in income.

1990s, although the full effects on the labour market are not yet apparent. In most highunemployment countries, nonetheless, only limited or piecemeal reforms have been introduced, and there has been generally no improvement, or in some cases a deterioration, in the number of jobs coming onto the labour market.

Since employment is the single most important source of market income (that is, excluding government transfers), especially for those at the bottom of the income distribution, the performance of the labour market plays a determinant role in inequality of income. There is a feeling in many quarters that adopting at least some of the policies recommended in the Jobs Strategy such as labour-market deregulation, more flexible wage-bargaining arrangements and reductions in minimum wages - could lead to an unacceptable widening of earnings and income distributions. Since such reforms are also important for the improved performance of the labour market, there may be a conflict between labourmarket reform and equity goals.
But the degree of conflict may be overstated. Improved job opportunities and lower unemployment contribute themselves to equity goals. Even if labour-market reforms widen the disparity of wage rates, the effect on disparities in overall wage-earnings will be offset, at least in part. Many of those with low monthly or annual earnings from wages do not have the opportunity to work very many hours; and those who cannot find employment at all, of course, have zero wage-earnings, regardless of wage rates. By

4. Riel Miller, Economic Flexibility and Societal Cobeston; The OECD Observer: No. 207, August/September 1997.

5. OECD Employment Outlook. OECD Publications, Paris, 1996.

6. George Papaconstantinoul, Technology and Johs; The OECD Observer No. 194, Junefuly 1995.

7. OECD Employment Outlook, OECD Publications, Paris, 1996; OECD Employment Outlook, OECD Publications, Paris, 1997: The OECD Employment Outlook - Low-wage Jobs: Stepping Stones or Traps?: The OECD Observer, No. 208, October/November 1997.

8. Paul E. Atkinson. New Zealand's Radical Reforms The OECD Observer No. 205, AprillMay 1997. 


\section{FOCUS}

\section{The Design of Fiscal Strategy in OECD Countries}

\section{Medium and Long-term Objectives}

Australia' Commonwealth 'underlying' budget balanced over economic cycle

Austria

Reduce federal deficit to $2.1 \%$ of GDP; freeze public expenditures on personnel, operating costs, social spending and subsidies to firms, in nominal terms

Belgium

Maintain general-government primary surplus around $6 \%$ of GDP; reduce budget deficit to around $1 \%$ of GDP and reduce debt-to-GDP ratio

Canada

Federal deficit to $1 \%$ of GDP en route to medium-term budget balance

Czech Republic Balanced state budget

Denmark

General-government balance in surplus over the business cycle

Finland

Stabilise and then reduce central government debt-to-GDP ratio

France

General-government deficit

Germany phase-in direct tax reform

Greece

Hungary

Iceland

Ireland

Italy

Japan

Reduce general-government deficit and debt-to-CDP ratios to $1.5 \%$ and around $61 \%$ of GDP respectively; reduce public spending to $46 \%$ of GDP (pre-unification spending figure); lower tax burden and budget deficit and lower social-security contributions below $40 \%$ of gross wages

Reduce general-government deficit and debt-to-GDP ratios to $0.9 \%$ and $103 \%$, respectively

Reduce general-government deficit and the size of public sector

Run a small surplus so as to reduce debt-to-GDP ratio from $48 \%$ to $40 \%$

Limit general-government deficit to $1.5 \%$ of GDP; use contingency reserve only to compensate cyclical shortfall of revenue $(0.7 \%$ of GDP); allow for definitional change in measurement of net lending arising from instruction of new reporting standards; meet all future EU targets

Reduce general-government deficit and debt-to-GDP ratios to $2.8 \%$ and $113 \%$, respectively

Contain central-local government deficit to $3 \%$ of GDP; limit issue of government bonds to those required to finance construction; limit share of expenditure to national income to $45 \%$ by 2000 and to $50 \%$ by 2025

Korea

Keep budget in balance; gradually raise tax and spending share in economy

Luxembourg

Mexico

Netherlands

Central-government expenditure to grow in line with medium-term GDP growth

Switzerland

Maintain balanced budget

Reduce tax and social-security burden and reduce public-sector deficit below 3\% of GDP

New Zealand

Budget balance

Operating surplus average just under $3 \%$ of GDP over three fiscal years; gross and net public debt-to-GDP ratios to decline to around $25 \%$ and $20 \%$, respectively

Norway

Consolidate general-government surplus; central-government surplus to be invested in foreign assets; underlying growth of central-government expenditure held to a maximum of $1 \%$

Poland

Reduce government revenues by $1 \%$ of GDP and spending by $2 \%$ of GDP;

reduce state budget deficit and public debt-to-GDP ratios to around $1 \frac{1}{2} \%$ and $42 \%$, respectively; reform tax and pension systems

Portugal

Reduce general-government deficit and debt-to-GDP ratios to $1.5 \%$ and $59.4 \%$, respectively

Spain

Reduce general-government deficit and debt-to-GDP ratios to $1.6 \%$ and $65 \%$, respectively

Sweden ${ }^{2}$

Surplus of $2 \%$ of GDP on the general-government balance over the cycle to be approached incrementally over the 1998-2001 period; balance budget for municipalities and counties

Turkey First increase and then maintain public-sector primary surplus at $2 \%$ of GDP

United Kingdom ${ }^{3}$ Sound public finances over the medium term; zero PSBR

United States Balance the unified federal budget

1. Excluding sales of assets and debt repayments.

2. Time horizon applies to the budget for municipalities and counties.

3. Refers to pre-election plans. Time horizon applies to PSBR target.

Source: $O E C D$
Time Horizon

2000

2000

1998-99

1998-99

2001

2000

1999

2000

1999

1999

2003

(action front-loaded

to period FY 1998

to FY 2000)

2000

1998

2001

2000

2000

2000

2000

2000

2000

FY 1999

2002 
increasing the flexibility of markets and improving the incentives to take jobs (and, on the part of firms, to offer them), labour and productmarket reforms can lead to wider opportunites for employment. Such reforms can thereby help to raise the overall incomes of those who now find themselves at the bottom of the income distribution precisely because of lack of employment opportunities.

Nevertheless, in introducing labour-market reforms, governments should be ready to deal with the possibility that some groups may be marginalised, as well as with the costs of re-absorbing workers who are displaced. One response, of course, is to maintain disposable incomes by extending public redistributional programmes. Raising taxes to pay for this approach is an unattractive option in many countries where tax burdens are already high. And higher taxes and transfers would tend to distort markets further, the labour market in particular. In principle, tax increases could be avoided or mitigated by reducing outlays on other public programmes. Yet cutting education, investment and other programmes to pay for extra transfers may have adverse consequences for mediumterm growth.

Thus the decision on how much, if at all, to expand redistributional programmes and, if so, how to pay for doing so involves complicated trade-offs. Theory suggests that transfer programmes and taxes distort economic activity and thereby reduce growth. The empirical analysis that might confirm this suggestion, unfortunately, is hindered by theoretical ambiguities and statistical difficulties. It is well known, for example, that in theory government programmes or taxes can offset market failures and thereby raise economic output. Perhaps the most common ex-

9. Pbillip Mckenzie and Gregory Wurzburg, Lifelong Learning and Employability; The OECD Observer, No. 209, December 1997january 1998.

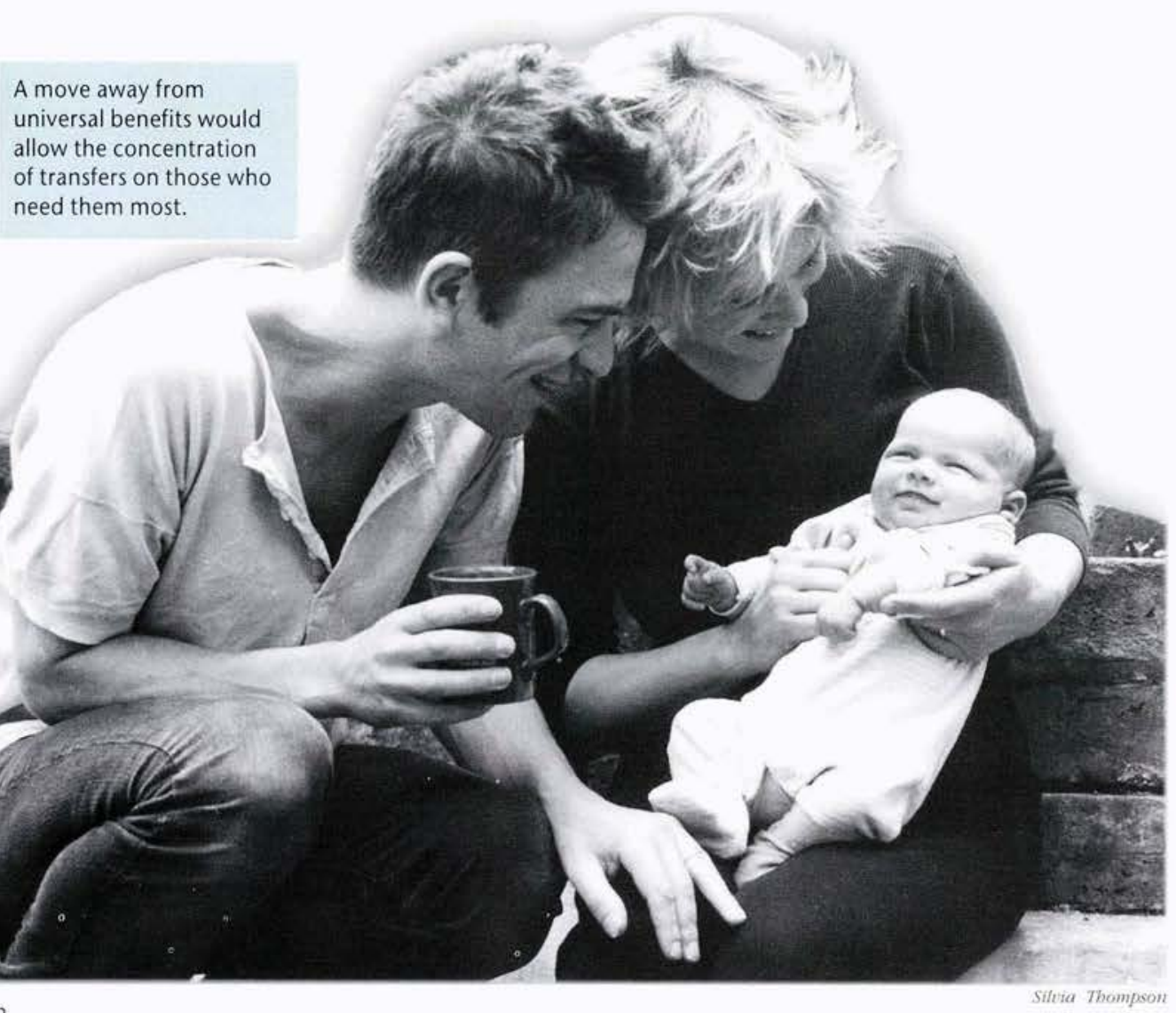

ample is environmental policy, which ideally compensates for the market failure that air, for example, belongs to no one in particular and so polluters are not charged for their use of it. An example close to the issue of income distribution is investment in education. Even though such investment appears to have high individual and social returns, it is very difficult to borrow against the high future wages educational investment might bring (owing, for example, to the lack of collateral that such a debt contract would imply). As a result, there may be underinvestment, especially among the poor. ${ }^{9}$

Statistical limitations include poor international comparability of the data on the distribution of income and earnings; and they do not exist for the long periods over which interactions between growth and distribution would be expected to play out. Average tax and transfer rates, which are available, may not closely approximate to the marginal rates that are relevant for explain- ing economic behaviour and the costs of changes to tax and expenditure programmes. And it is difficult to quantify the full range of redistributive policies, which include regulations and subsidies of various sorts as well as taxes and transfer programmes.

\section{Two Bites at the Cherry?}

An alternative to increases in taxes and transfers would be reforms of tax and transfer systems to increase their effectiveness - while containing budgetary costs. Very generous transfer programmes can reduce the incentive to take and keep employment, especially if they are linked directly to employment (unemploymentinsurance benefits, for example), That is, these programmes can take the form of an 'unemployment trap' if the benefits lost by taking work 


\section{Fiscal Consolidation, Crowth and Equity}

substantially reduce incentives to do so, or a 'poverty trap' if taxes or benefit withdrawals reduce substantially the increase in income from increased work effort.

Several countries - Canada, Ireland, Italy, the United Kingdom and the United States - have aimed to reduce the unemployment trap by implementing programmes that substitute in-work benefits for income support (the largest of these by far is the Earned Income Tax Credit of the United States). In-work benefits encourage jobtaking by providing support only to the employed. But with pressure on budgets, the higher in-work benefit must ultimately be phased-out rapidly, which would tend to lead to the poverytrap problem.

In-work benefits are nonetheless particularly desirable if the goal is to increase the number of people in work. Yet such benefits do not protect those out of work - and generous benefits that do not depend on being emploved undermine the incentives of in-work benefits. An alternative approach has been adopted by a few continental European countries, chiefly France, which has reduced non-wage labour costs at the lower end of the wage scale by adjusting payroll tax rates.

It may be possible to reduce the problem of the poverty trap by targetting transfers towards the people who require them most pressingly by selecting characteristics other than income and that are difficult for potential recipients to disguise. Many programmes are targeted at families with children, for example; but rich people also have children, which weakens the targetting. The poverty trap can also be reduced by ensuring that the presence of someone earning a second income does not trigger high taxes and the loss of benefits for a household unit.

\section{a}

The combination of fiscal restraint, concerns about income disparities and the rising pressures on government budgets due to population aging will focus increasing attention on refining the essential priorities of the public sector, and on the issues of designing programmes and tax systems which meet those priorities at the least cost

10. OECD Economic Outlook, No. 60, OECD Publica thons, Paris, December 1996. to economic performance and growth. Many of the decisions that will have to be made in this context depend on knowledge of trade-offs, benefits and costs that is still underdeveloped. Not enough is known about income distribution and, especially, about how individuals and families fare over time - even over their lifetimes. And the economic effects of existing and proposed transfers and taxes are still unclear in many respects, which hinders the development and assessment of alternatives to current systems.

\section{OECD BIBLIOGRAPHY}

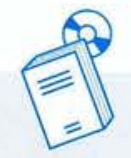

Implementing the OECD Jobs Strategy: Lessons from Member Countries' Experiences, 1997

Sveinbjöm Blondal and Stefano Scarpetta, The OECD Jobs

Strategy under Scrutiny', The OECD Observer, NNo. 209,

December 1997/lanuary 1998

OECD Economic Surveys: Japan, 1997

Randall S. Jones, 'Japan - Population Aging',

The OECD Observer, №. 209,

December 1997//anuary 1998

Literacy Skills and the Knowledge Society, 1997

Phillip McKenzie and Gregory Wurzburg, 'Lifelong

Leaming and Employability, The OECD Observer,

No. 209, December 1997//anuary 1998

The OECD Jobs Strategy: Enhancing

the Effectiveness of Active Labour Market Policies,

1996

Peter Schwanse, 'Activating the Unemployed',

The OECD Observer, №. 209,

December 1997//anuary 1998

Riel Miller, 'Economic Flexibility and Societal Cohesion',

The OECD Observer, №. 207, August/September 1997

OECD Employment Outlook, 1997

The OECD Employment Outlook - Low-wage Jobs:

Stepping Stones or Traps?', The OECD Observer,

№. 208, October/November 1997

Ageing in OECD Countries: A Critical Policy

Challenge, 1996

Lans Bovenberg and Anja van den Linden, 'Pension Policies and the Aging Society, The OECD Observer, No. 205, April/May 1997

OECD Economic Survey: New Zealand, 1996

Paul E. Atkinson, 'New Zealand's Radical Reforms',

The OECD Observer, No. 205, Apri//May 1997

Peter Hicks, The Impact of Aging on Social Policy',

The OECD Observer, №. 203,

December 1996//anuary 1997

OECD Economic Outlook, №. 60, 1996

Implementing the Jobs Strategy, 1995

Ceorge Papaconstantinou, Technology and Jobs',

The OECD Observer, №. 194, June//uly 1995.

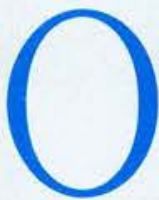

ver the past two decades health spending in Portugal has risen more rapidly than in other $\mathrm{OECD}$ countries, and on present policies the upward pressure on health outlays is likely to grow with the aging of the population and with medical advances. Reform of the health system will thus become more pressing, especially if increases in taxation or compensatory cuts in other primary spending are to be avoided in order to meet budget deficit targets required under the 'Stability and Growth Pact' (for countries joining Economic and Monetary Union). ${ }^{1}$

Total spending on health care increased from $2.8 \%$ of GDP in 1970 to $8.6 \%$ in 1996 , exceeding the EU equivalent by 0.5 percentage point. Mirroring this sharp rise in spending, health outcomes improved vastly over that period. The infant mortality rate was reduced by four-fifths and the 'potential life years lost' for males (PLYL, a crude measure of avoidable premature death) was cut by nearly a half. Indeed, progress in health performance has in general been much more marked than elsewhere.

Portugal's health outcomes are nonetheless still below those found elsewhere. There is equally evidence that they vary among income groups and particularly strongly across regions. Access to health services and the efficiency with which they are provided is also highly uneven. The impressive scale of improvement in health results has thus been inadequate in relative terms. Judging by the performance of other OECD countries, the sharply rising factor inputs should have yielded larger and more uniform improvements in health outcomes. Portugal's health sector stands out by its low relative efficiency.

The main forces underlying the rise in health expenditure in the 1980s and '90s were the introduction of the National Health Service (Serviço Nacional de Saúde, or SNS) in 1979, demographic changes, the jump in per capita income (which reached $69 \%$ of the EU-15 average in 1997, up from $54 \%$ in 1985) and changes in relative prices.

Marcos Bonturi works in the Country Studies Branch of the OECD Economics Department.

E-mail: eco.contact@oecd.org 


\section{Portugal The Health System}

Marcos Bonturi

The number of persons over 65 years rose from $11.4 \%$ of the total population in 1981 to $14.8 \%$ in 1995. Like most other countries, Portugal also experienced a rise in relative prices for health care. Over the five years to 1996, consumer prices for health services and products jumped by nearly $60 \%$, rising almost twice as fast as prices in general. Fees for medical and paramedical services, which are unregulated in the private domain, and prices for therapeutical material showed the strongest increase.

\section{A Complex Mix of Private/Public Provision}

The rapidly growing demand for health services in Portugal has been associated with an atypical mix of public and private health-care provision. Public outlays on health, at almost $5 \%$ of GDP, are marginally lower than the OECD average. But private spending, at $3.3 \%$ of GDP, is more than twice as high, surpassing all other OECD countries except the United States. Indeed, high private health expenditure has been a historical feature of Portugal's health market. Before the establishment of a universal system of health care in 1979, non-profit hospitals and ambulatory units belonging to 'social welfare' fulfilled a role as supplementary providers of health care when private provision failed.

Institutional reforms following the 1974 revolution culminated in the creation of the SNS which, by introducing universal and comprehensive health care free of charge, aimed at breaking the pattern of highly unequal access to health services. Most non-profit hospitals were brought into the public domain and publicly sponsored ambulatory units were integrated in the national health service as 'health centres'. By contrast, 'health sub-systems' (available to some professional categories) which had grown up mainly in the public sector were allowed to remain in-

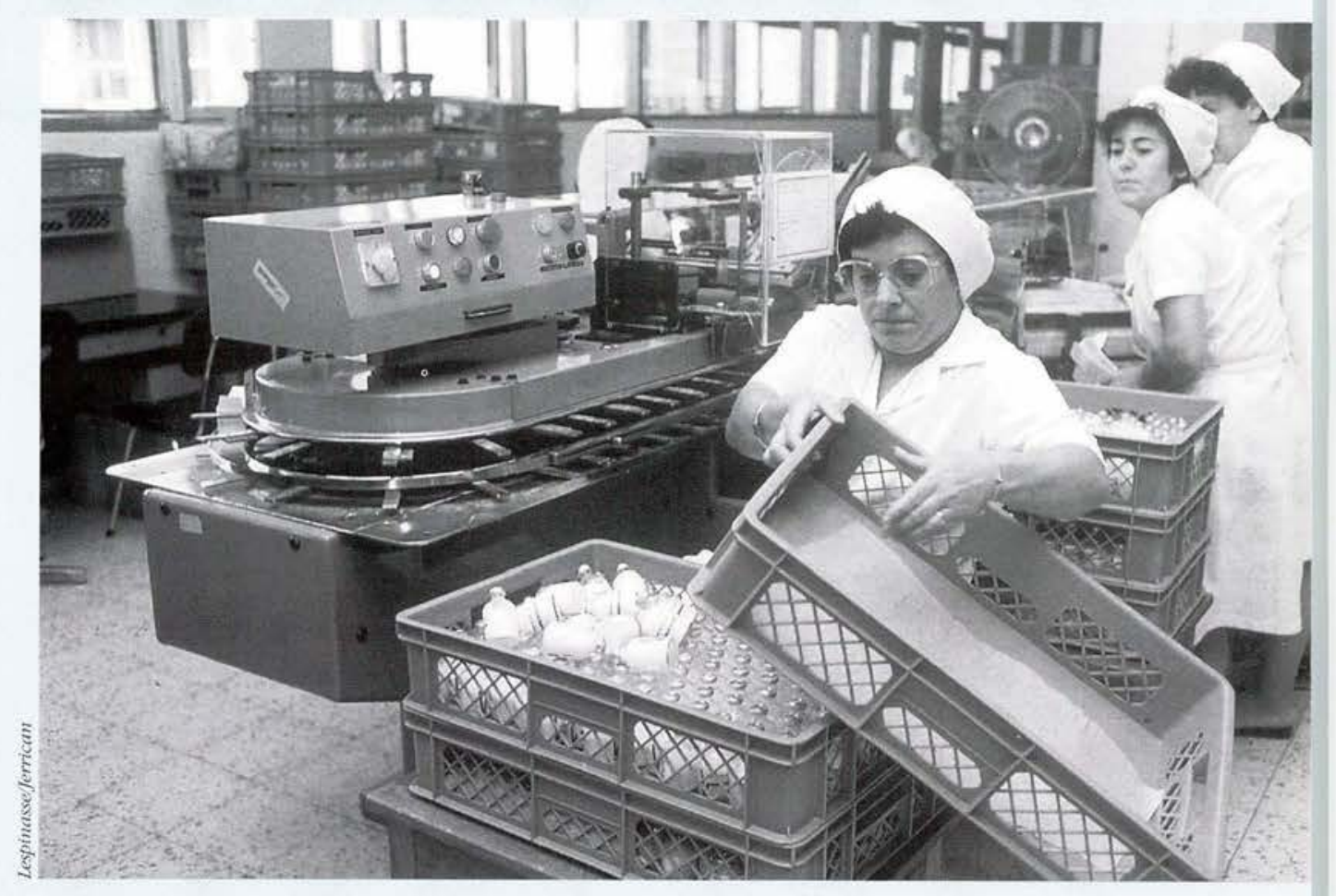

dependent. Since 1979, the Portuguese health system has thus been based on three potentially overlapping tiers:

- the SNS available to all residents, financed and operated by the public sector

- special sub-systems for specific professional categories, covering a quarter of the population - the private sector, including insurance schemes and mutual institutions, covering respectively 10 and $7 \%$ of the population.

\section{Efficiency and Incentives}

Underlying the inefficiency in providing health services has been a complex set of adverse incentives. Doctors employed by the SNS draw a remuneration which is linked to professional category and length of service rather than work effort or performance; the result is a lack of salary incentives. In after-tax terms, the potential for incremental earnings in the unregulated private sector often exceeds the exclusivity premium paid in the public sector, which produces a clear incentive to set up private practices. The dual employment status has had the joint effect of lowering the value for money of SNS-rendered services - leading to low-work intensity and long waiting lists for some non-urgent surgical procedures - while simultaneously exacerbating problems of accessibility. This incentive structure has been underpinned by institutional features stimulating demand for private health services as a result of unlimited tax deductibility for health spending and the possibility, in some

1. OECD Economic Surveys: Portugal OECD Publi cations, Paris, 1998. 


\section{Portugal The Health System}

circumstances, of obtaining access to private health care under SNS coverage.

A similar lack of incentives characterises the public hospital administration, which faces no hard budget constraints and whose planning and management roles are limited. Managers and administrators, being civil servants with life-time contracts, draw salaries unrelated to hospital performance as a whole. Salaries usually account for $80 \%$ of hospital current outlays, but health institutions lack management autonomy, not least in staff policy. Because of administrative hurdles, many hospitals also lack capital equipment, also contributing both to long waiting times (one to two years for some operations) and to large purchases by hospitals of laboratory services in the private sector. Since no systematic medical records are kept, the flow of information among doctors and health institutions has naturally been thin.

With the public sector having to compete with high private-sector fees, and hospital wage bills and medical fees claiming the bulk of resources, health centres have suffered from under-equipment of capital, and under-endowment of quality labour, especially in poor regions. The absence of management autonomy, combined with the bureaucratic rules governing health centres, has led to inefficient modes of service, contributing to discontent among users and demotivation among doctors. In this situation, health centres have been unable to meet the demand for ambulatory services, diverting demand to hospitals and contributing to the overcrowding of hospital emergency rooms, which absorb about a fifth of hospital budgets.

Conversely, the number of prescriptions per consultation is high compared to most other countries. Several institutional features have favoured drug consumption, prominent among them low effective co-payments and tax deductibility, SNS reimbursement for drugs prescribed under private treatment (since 1995) and comparatively low prices. There is also a problem of administrative complexity, pharmacies being reimbursed through the pharmacy association.

In this setting, large and rising cost overruns were bound to appear. Unexpected hospital outlays are directly covered by the Ministry of Health with no involvement of regional health administrations, a form of passive financing which makes for a weak budget constraint. Since they are based upon historical developments, most hospital budgets have inevitably incorporated such cost overruns. Portugal's relatively high health spending has been associated with the complexity of overlapping insurance schemes and over-coverage (135\% of the population). Duplication of insurance coverage has in turn encouraged over-consumption of medical services, as patients may consult several doctors at a time. With recourse to health services outside the NHS being stimulated by long waiting times for certain public services and overcrowded emergency rooms in hospitals, the combination of universality and private provision has created an adverse set of incentives without achieving equity objectives. Tax privileges have reinforced this trend.

\section{Options for Reform}

It is apparent from the collective experience of OECD countries that health systems are prone to a common set of problems, which may lead to a strategic misallocation of resources within the health sector, operational inefficiencies in management structures and overall weak budget constraints. These problems tend to occur in systems where health-care provision is universal, comprehensive and free of charge. In principle, there are three main options for easing these problems: to create appropriate incentive structures within the public sector as a universal provider; to replace the public system by a set of private contractual relationships; or to ensure a balanced co-existence of public and private schemes.

Under the third option, several variants can be considered. One variant makes opting out of the public system possible, yielding savings in terms of contributions or taxes paid for the public system which could be used for the purchase of exclusive private health insurance. With a second variant (top-up model), members of the public system would be free to buy private health insurance as a complement to the public scheme. A third variant would consist in maintaining universal provision by the SNS of a comprehensive set of health services, but for a defined subset of services consumers would be required to opt for either private or public coverage. This last approach could be specifically adapted to the complexities of the current institutional set-up in Portugal, so as to enhance both equity and efficiency.

Reforms are currently at an experimental stage, institutional changes being made at the margin: the systemic impact is therefore bound to emerge only slowly and gradually. An independent commission set up by the government to study and propose alternatives for health-care reform presented its findings in December 1997. leaning towards the third option of a balanced mix between private and public provision. In view of the scale of existing imbalances and related upward pressure on spending, the current reform process should be reinforced and intensified. Policy initiatives are required to increase the efficiency of health care provided by the SNS; strengthen incentives for private health suppliers to reduce costs in a sustainable manner; and improve incentives for households to use health care services economically and to place more emphasis on prevention.

\section{OECD BIBLIOGRAPHY}

OECD Economic Surveys: Portugal, 1998 Eckhard Wurzel, 'Cermany. The Welfare System', The OECD Observer, No. 202, October/November 1996 OECD Economic Surveys: Portugal, 1996 Flavia Terribile, 'Portugal: Reforming the Social-security System', The OECD Observer, №. 201, August/September 1996

New Directions in Health Care Policy, 1995 The Reform of Health Care Systems: A Review of 17 OECD Countries, 1994. 


\title{
The Russian Federation
}

\section{Commercial Banking}

\author{
John Litwack
}

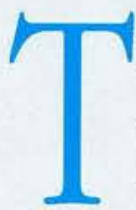

he development of capital markets and commercial banking presents some of the most difficult policy challenges for countries in transition to a market economy. The operation of capital markets in most OECD countries, involving the guaranteeing of relatively long-term contracts under conditions of limited liability and imperfect information, relies on a host of complex institutions that have developed over a long period of time.

In addition to the enforcement of laws affecting contracts, bankruptcy, disclosures, insurance and the rights of creditors and stockholders, these institutions also include business reputations, sophisticated credit-rating systems, frameworks of corporate governance for the disciplining of management, skills for the monitoring and evaluation of specific investment projects, and cooperative agreements for pooling information.

The very nature of economic transition entails a high degree of uncertainty and risk, adding even more difficulties for the creation and effective operation of these institutions. Experience since World War II suggests that commercial banks may be able to play a key role in this process of institutional evolution, even while the stock market remains very weak.

\section{Striking Dynamism}

The growth of commercial banking in the Russian Federation in the 1990s has been dynamic. Russia began economic transition without even the semblance of a banking sector as exists in a market economy. Branches of the state

John Litwack works in the Central and Eastern Europe Division of the OECD Economics Department.

E-mail: eco.contact@oecd.org banking monopoly functioned essentially by intermediating financial flows between the state and economic organisations on the basis of administrative directives. In the late 1980s, the branches of the state banking hierarchy were transformed into commercial banks and placed under the direct regulation of the Central Bank. By the mid-1990s, over 2,500 commercial banks were operating throughout the country, most of which were newly created and private.

During the first years of transition, the vibrancy, growth and profitability of commercial banking contrasted sharply with most other branches of the economy. In more recent years, a handful of large Moscow banks have risen to prominence as the most advanced and best capitalised financial institutions in the country, performing on a daily basis complicated operations on financial markets that were completely foreign to Russia only a few years ago.

This rapid growth in commercial banking has been important for the development of capital markets. But it has also created a serious dilemma. It has by far outpaced the evolution of the institutions necessary to support the effective financial intermediation by banks of savings and investment under the 'normal' conditions of a market economy.

The impressive growth of commercial banking during the early years of transition in Russia derived from a very specific and largely transitory regulatory and economic environment. Very lax minimal capital requirements and other prudential regulations made the establishment and operation of new banks quite easy. Negative real interest rates on deposits and refinance credits allowed banks to profit simply by holding a large share of assets in hard currency. Rapid inflation and poor payment discipline provided another important source of bank profits: the delaying of various payments, usually at the expense of the government or state-owned enterprises.
Rapid and unstable inflation supported a high demand for the service of foreign currency exchange. Lax foreign-exchange regulations allowed banks to service capital outflows through excessive payments for (possibly fictitious) imports. In addition, a large amount of implicit subsidies in the form of Central Bank credits and other state resources were intermediated by commercial banks during this period. By offering interest rates somewhat higher than the State Savings Bank (Sberbank), many new banks also attracted a larger share of household deposits during this period.

All of these sources of profits for commercial banks have been eliminated or substantially decreased after changes in economic policies and progress in stabilisation (Table). Monetary policy has tightened sharply, and directed credits have been largely discontinued since 1994, as mirrored in the contraction of bank credit in GDP from 34\% at the end of 1992 to $10 \%$ by 1997 . Progress in stabilisation, assisted by much lower inflation and less volatility in exchange rates, has reduced profits from inflation rents, the servicing of currency exchange and speculation. Real interest rates have gone from being highly negative in 1992 and 1993 to being highly positive from the second half of 1994 until the end of 1996. Charter capital requirements and other prudential regulations have been tightened substantially, and are still to be progressively stiffened to meet many of the main Basel standards by 1999 . The authorities have also devoted more resources and legislation to monitoring foreign-exchange operations and uncovering capital outflows disguised as current-account bank payments, although this is reportedly still a problem.

These very sharp changes, many of which came in late 1994 and early 1995, placed a

1. OECD Economic Surveys: The Russian Federation. OECD Publications, Paris, 1997. 
Table

The Evolution of Russian Banking, 1992-96

as at 31 December, unless otherwise stated

\begin{tabular}{|l|}
\hline Number of operating credit organisations' \\
\hline Licences withdrawn (number, cumulative) \\
\hline Charter capital requirement for new banks ( $\$$ thousands) \\
\hline Real monthly refinance rate of CBR' $(\%)$ \\
\hline Credit from monetary authorities to commercial banks \\
\hline Bank credit to the non-financial sector \\
\hline Interbank credit received \\
\hline Gross assets of the banking sector \\
\hline Household deposits \\
\hline Household deposits outside of Sberbank \\
\hline
\end{tabular}

\begin{tabular}{|r|r|r|r|r|}
\hline 1992 & 1993 & 1994 & 1995 & 1996 \\
\hline 1,713 & 2,019 & 2,517 & 2,295 & 2,030 \\
.. & 13 & 78 & 303 & 592 \\
214.4 & 70.6 & $1,244.7$ & $1,291.5$ & $3,648.9$ \\
-12.2 & -6.9 & 4.4 & 7.6 & 6.5 \\
& \multicolumn{4}{|c}{ \% of GDP } \\
15.0 & 5.1 & 2.4 & 1.1 & 0.6 \\
33.6 & 20.4 & 19.6 & 12.0 & 10.0 \\
.. & 3.2 & 4.9 & 3.9 & 3.1 \\
88 & 54 & 56 & 36 & 36 \\
1.9 & 2.4 & 4.2 & 4.3 & 5.3 \\
0.3 & 0.9 & 1.7 & 1.5 & 1.4 \\
& & & & \\
\hline
\end{tabular}

... not available.

1. 1,360 at the end of 1991.

2. Central Bank of Russia; yearly average of real monthly rates; for 1992 February-December (so as to exclude the price jump in January).

Sources: CBR, IMF, OECD

number of banks in immediate financial trouble. Growing liquidity and portfolio problems culminated in the collapse of the interbank loans market in August 1995 on the heels of a chain of defaults. Instead of providing the accommodation that was characteristic of past policies toward distressed commercial banks, the central-bank authorities used the event to signal the seriousness and credibility of the new tougher policy course.

Refinancing was very limited and concentrated only on a few of the larger banks that presented systemic risk. Simultaneously, the Central Bank began to withdraw the banking licenses from many distressed banks, a process that had reduced the number of operating banks to roughly 1,800 by September 1997 .

In view of the absence of comprehensive deposit insurance, the large number of bank and other financial failures in recent years reversed the trend toward the attraction of household deposits by other commercial banks away from Sberbank. After rapidly increasing to $41 \%$ at the end of 1994, the share of household deposits in other banks than Sberbank fell back to $26 \%$ by the end of 1996.
Two years after the crisis on the interbank market, the overall situation in the Russian banking sector remains very difficult. The tough policy course of the Central Bank has nevertheless borne some fruit. Predictions by some of an immediate repetition of the crisis on an even larger scale have not materialised, while the incentives facing the commercial banks, and their behaviour, have changed dramatically. One important indication of this change is the contraction of commercial credit in GDP, which directly reflects more cautious bank policies. Although the share of commercial credit in GDP at the end of $1996(10 \%)$ is quite low even relative to other transition economies, it can be argued that this properly reflects the low degree of institutional development of Russian credit markets. Policies that supported a high share of new commercial credit in GDP under similar institutional conditions in Bulgaria, for example, eventually led to a full-blown financial crisis in 1996 and the virtual collapse of its banking sector. ${ }^{2}$ It is notable that, during a time of escalating interenterprise and various budgetary arrears in Russia between 1995 and 1997, the reported share of arrears in all commercial credit fell continuously from $43 \%$ in October 1994 to under $13 \%$ by mid1997. Problems in accounting and monitoring have led to estimates that the figure might currently be closer to $30 \%$. But in view of the difficulties the Russian economy is facing, the controlling of credit arrears must be considered a success for central-bank policies - at similar stages in economic stabilisation in almost all other transition economies such arrears increased.

How have some Russian commercial banks managed to survive the elimination of most of their earlier sources of profits? They have been channelling a much larger share of their assets into credits and investments in securities (Figure). In January 1995, most of their assets were 'nonworking, most of that in hard currency. By two years later commercial credits or investments in securities jumped to $70 \%$ of banking assets. With most other sources of profits vanishing, the market for state securities has offered commercial banks a particularly important opportunity for investment. That was especially in 1996, when access to the market by foreigners was highly restricted and interest rates soared, owing partly to a high federal budget deficit and much political uncertainty. The share of bank assets invested in securities grew from 6 to 18\% between 1995 and 1997.

\section{Moscow and Elsewhere}

In the last few years a very strong dichotomy has emerged between a handful of rapidly growing large Moscow banks and the rest of the banking sector, most of which has been experiencing increasing financial distress. This process has increased significantly the degree of concentration in the industry, with large Moscow banks accounting for over $70 \%$ of assets, close to $80 \%$ of credits, and roughly $90 \%$ of household deposits by January 1997. These banks are also actively penetrating most regions in the Federation, increasing their shares in, and, in some cases, domination of, regional markets. Some regional governments have adopted policies aimed at protecting their local banks, but financial problems have increasingly pressured most 
of these governments to abandon such efforts in favour of attracting capital and financial services from Moscow to the region.

The rise of these large Moscow banks has been one of the most prominent features of the Russian economic landscape in the past few years. They operate as universal banks, typically at the centre of extensive financial-industrial groups, and have been the most active players on the emerging market for corporate control. The close relationships that these banks have forged with various government organs have also been a focal point of controversy. Some banks appear to have received privileged access to several privatisation auctions. Several have profited from obtaining the authorisation' to participate in state financial programmes, which can involve the holding of budget funds at negligible interest rates or lucrative credit issues with state guarantees.

The government formed in March 1997 announced the goals of reducing or eliminating these special privileges, and eventually transferring all federal finances to the National Treasury. In addition, enhanced political stability and the sequential opening of the state securities market to foreign investors, beginning in the second half of 1996, have driven down interest rates on government bonds dramatically, thereby decreasing the profitability of many banks. Immediately after assuming the position of First Deputy Prime Minister and Minister of Finance, Anatoly Chubais announced, at the Congress of the Association of Russian Banks in April 1997, that banks would no longer be able to survive on the basis of state favours and high yields on state securities: "For banks there remains only one path: investment in the real sector. Those who are late to realise this will lose, and those who do not realise it will perish financially'?

But success in re-orienting banks toward credits for investment and restructuring depends

2. OECD Economic Surveys: Bulgaria 1996-1997, OECD Publications, Paris, 1997.

3. Quoted in OECD Economic Surveys: Tbe Russian Federation.
Figure

The Structure of Russian Commercial Bank Assets, 1995-97

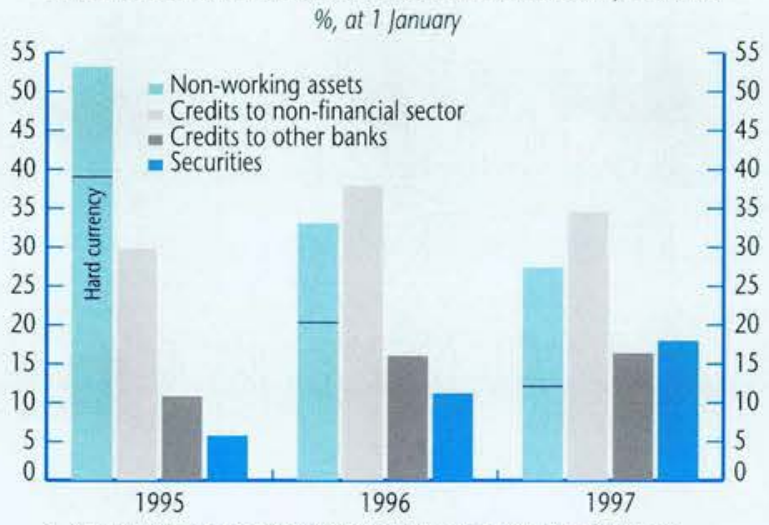

1. Based on a sample of 503 Moscow banks, excluding Sberbank and Vneshekonombank.

Source: Laboratoria Problem Finansovogo Sektora, TsEMI RAN, Moscow
Special bilateral relations with government organs are therefore still widely viewed within Russia as a prerequisite for successful business.

The behaviour of these large Moscow banks can thus be viewed largely as a response to the particular environment of the Russian economy, which continues to suffer from the absence of rule of law. A comprehensive strategy for simultaneously improving the health of the banking sector and reorienting commercial banks toward more involvement in the restructuring process should combine policies aimed at phasing-out state favours with other measures to promote the development and enforcement of economic laws in a few key areas. In particular, the rights of commercial on more than the elimination of government favours and reduced yields on state securities. Indeed, investment (long-term) credits other than those issued with state guarantees have remained a negligible part (less than $2 \%$ ) of commercial bank assets throughout the transition period. That not only reflects the presence of other sources of profits but also the very low stage of development of institutions to support the operation of credit markets. Legal protection of the rights of creditors, even in the case of secured loans, remains extremely weak. In addition, enterprises have been predominantly employee-controlled since mass privatisation, and no effective mechanism yet exists for disciplining management or replacing incompetent managers on a large scale.

These problems appear to provide some of the motivation for banks to form financialindustrial groups and obtain controlling shares of client firms. Commercial banks are very reluctant to lend to firms that they do not control. The fact that these banks and their group affiliates seek to operate on the basis of special bilateral agreements with various government bodies also derives from the nature of the current business environment in the country. Key economic variables in areas such as taxation, customs duties, trade, and access to transportation remain very unstable and subject to a high degree of discretionary control at various tiers of government. creditors in the event of default should be strengthened, allowing them easier options for seizing collateral or initiating a turnover of enterprise management. This latter option could also facilitate the ability of commercial banks, through debt contracts, to make an important contribution to the establishment of effective corporate governance and combat the problem of insider control.

Several Russian commercial banks are poised to make a potentially important contribution to the development of the Russian economy in the near future. But the nature of this contribution depends a good deal on the success of many overdue reform measures to promote a stable policy environment based on the rule of law, including a strong defence of the rights of creditors.

OECD BIBLIOGRAPHY

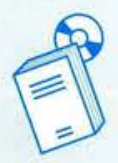

OECD Economic Surveys: The Russian Federation, 1997

OECD Economic Surveys: Bulgaria 1996-1997, 1997. 


\section{Indicators}

\begin{tabular}{|c|c|c|c|}
\hline \multicolumn{4}{|c|}{ AUSTRALLA } \\
\hline & \multirow[t]{2}{*}{ period } & \multicolumn{2}{|c|}{$\begin{array}{c}\% \text { change } \\
\text { from previous }\end{array}$} \\
\hline & & period & year \\
\hline Gross Domestic Product & Q397 & 1.1 & 2.8 \\
\hline Leading Indicator & Nov. 97 & -0.1 & 3.1 \\
\hline \multirow[t]{2}{*}{ Consumer Price Index } & Q397 & -0.4 & -0.3 \\
\hline & & $\begin{array}{l}\text { current } \\
\text { period }\end{array}$ & $\begin{array}{l}\text { same period } \\
\text { last year }\end{array}$ \\
\hline Current Balance & Q397 & -3.41 & -3.91 \\
\hline Unemployment Rate & Nov. 97 & 8.4 & 8.5 \\
\hline Interest Rate & Nov. 97 & 4.97 & 6.42 \\
\hline
\end{tabular}

\begin{tabular}{|c|c|c|c|}
\hline \multicolumn{4}{|c|}{ BELGIUM } \\
\hline & \multirow[t]{2}{*}{ period } & \multicolumn{2}{|c|}{$\begin{array}{l}\% \text { change } \\
\text { from previous }\end{array}$} \\
\hline & & period & year \\
\hline Gross Domestic Product & Q297 & 1.3 & 3.0 \\
\hline Leading Indicator & Oct. 97 & 1.0 & 7.1 \\
\hline Consumer Price Index & Dec. 97 & -0.1 & 1.1 \\
\hline & & $\begin{array}{l}\text { current } \\
\text { period }\end{array}$ & $\begin{array}{l}\text { same period } \\
\text { last year }\end{array}$ \\
\hline Current Balance & Q297 & 3.70 & 3.64 \\
\hline Unemployment Rate & Oct. 97 & 9.4 & 9.6 \\
\hline $\ln$ & 97 & 360 & 3.00 \\
\hline
\end{tabular}

\begin{tabular}{|c|c|c|c|}
\hline \multicolumn{4}{|c|}{ Denmark } \\
\hline & \multirow[t]{2}{*}{ period } & \multicolumn{2}{|c|}{$\begin{array}{l}\% \text { change } \\
\text { from previous }\end{array}$} \\
\hline & & period & year \\
\hline Gross Domestic Product & Q297 & 1.4 & 3.1 \\
\hline Leading Indicator & Oct. 97 & 0.3 & 3.3 \\
\hline \multirow[t]{2}{*}{ Consumer Price Index } & Nov. 97 & 0.1 & 2.1 \\
\hline & & $\begin{array}{l}\text { current } \\
\text { period }\end{array}$ & $\begin{array}{l}\text { same period } \\
\text { last year }\end{array}$ \\
\hline Current Balance & Q397 & 0.54 & 1.28 \\
\hline Unemployment Rate & Oct. 97 & 5.8 & 6.6 \\
\hline Interest Rate & Dec. 97 & 3.90 & 3.60 \\
\hline
\end{tabular}

\begin{tabular}{|c|c|c|c|}
\hline \multicolumn{4}{|c|}{ Germany } \\
\hline & \multirow[t]{2}{*}{ period } & \multicolumn{2}{|c|}{$\begin{array}{l}\% \text { change } \\
\text { from previous }\end{array}$} \\
\hline & & period & year \\
\hline Gross Domestic Product & Q397 & 0.8 & 2.3 \\
\hline Leading Indicator & Oct. 97 & 0.0 & 8.4 \\
\hline Consumer Price Index & Nov. 97 & 0.0 & 1.9 \\
\hline & & $\begin{array}{l}\text { current } \\
\text { period }\end{array}$ & $\begin{array}{l}\text { same period } \\
\text { last year }\end{array}$ \\
\hline rrent Balance & Oct. 97 & -2.80 & -1.45 \\
\hline Unemployment Rate & Oct. 97 & 10.0 & 9.0 \\
\hline Interest Rate & Dec. 97 & 3.74 & 3.23 \\
\hline
\end{tabular}

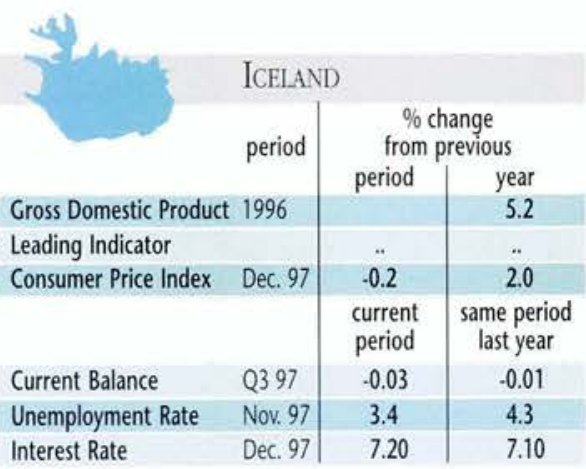

\begin{tabular}{|c|c|c|c|}
\hline & \multicolumn{3}{|c|}{ AUSTRIA } \\
\hline & \multirow[t]{2}{*}{ period } & \multicolumn{2}{|c|}{$\begin{array}{l}\% \text { change } \\
\text { from previous }\end{array}$} \\
\hline & & period & year \\
\hline Gross Domestic Product & Q4 95 & 0.0 & 0.3 \\
\hline Leading Indicator & Oct. 97 & 0.9 & 7.1 \\
\hline Consumer Price Index & Nov. 97 & 0.1 & 1.1 \\
\hline & & $\begin{array}{l}\text { current } \\
\text { period }\end{array}$ & $\begin{array}{l}\text { same period } \\
\text { last year }\end{array}$ \\
\hline Current Balance & Oct. 97 & -1.00 & -1.15 \\
\hline Unemployment Rate & Oct. 97 & 4.5 & 4.4 \\
\hline Interest Rate & Dec. 97 & 3.84 & 3.35 \\
\hline
\end{tabular}
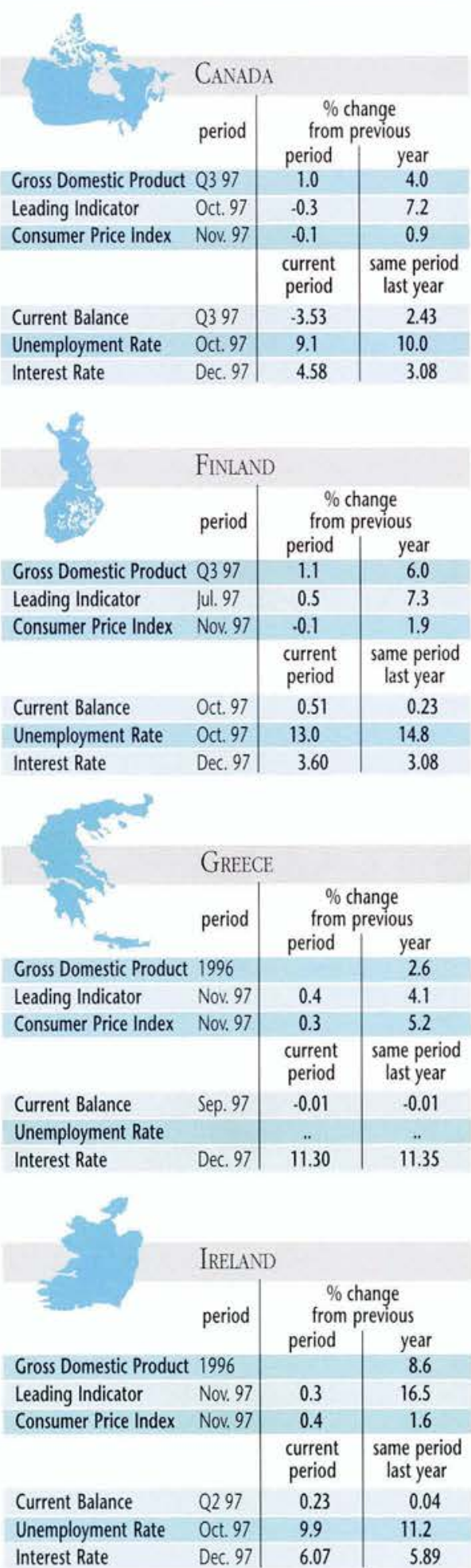

Definitions and Notes

Gross Domestic Product: Volume series, seasonally adjusted except for Czech Republic and Portugal

Leading Indicator: A composite indicator, based on other indicators of economic activity (employment, sales, income, etc.), which signals cyclical movements in industrial production from six to nine months in advance Consumer Price Index: Measures changes in average retail prices of a fixed basket of goods and services

Current Balance: \& billion; not seasonally adjusted except

for Australia, the United Kingdom and the United States

Unemployment Rate: \% of civilian labour force -

standardised unemployment rate; national definitions for

Czech Republic, Iceland, Korea, Mexico, Poland, Switzerland and Turkey; seasonally adjusted apart from Turkey

Interest Rate: Three months, except for Greece (twelve

months)

not available

Source: Main Economic Indicators, OECD Publications, Paris, January 1998

\begin{tabular}{|c|c|c|c|}
\hline \multicolumn{4}{|c|}{ Czech Republic } \\
\hline & \multirow[t]{2}{*}{ period } & \multicolumn{2}{|c|}{$\begin{array}{c}\% \text { change } \\
\text { from previous }\end{array}$} \\
\hline & & period & year \\
\hline Gross Domestic Product & Q397 & .. & 0.8 \\
\hline Leading Indicator & & .. & .. \\
\hline \multirow[t]{2}{*}{ Consumer Price Index } & Nov. 97 & 0.5 & 10.1 \\
\hline & & $\begin{array}{l}\text { current } \\
\text { period }\end{array}$ & $\begin{array}{l}\text { same period } \\
\text { last year }\end{array}$ \\
\hline Current Balance & Q297 & -0.85 & -0.93 \\
\hline Unemployment Rate & Nov. 97 & 5.0 & 3.3 \\
\hline Interest Rate & Dec. 97 & 17.50 & 12.67 \\
\hline
\end{tabular}

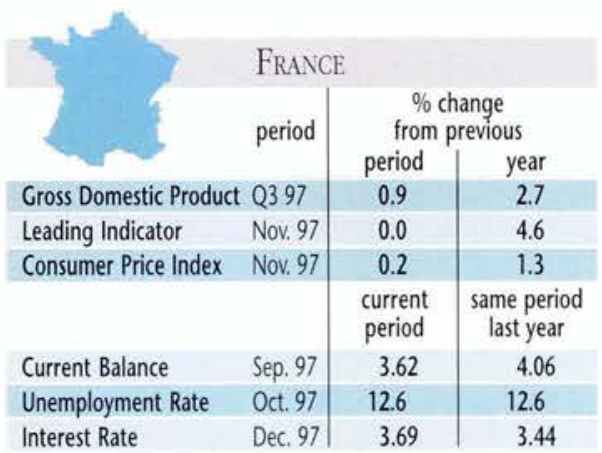


Observer Exclusive

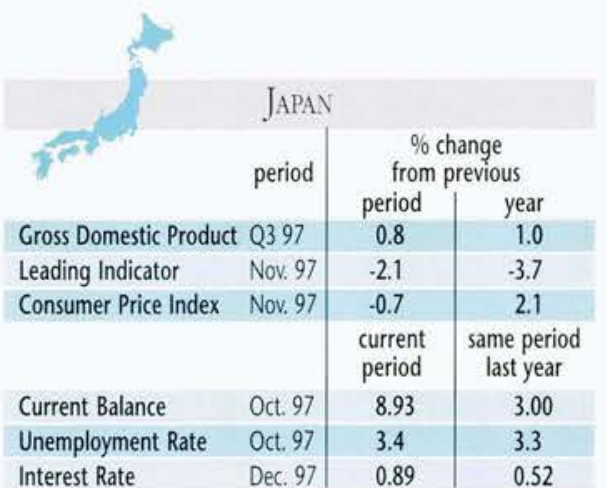

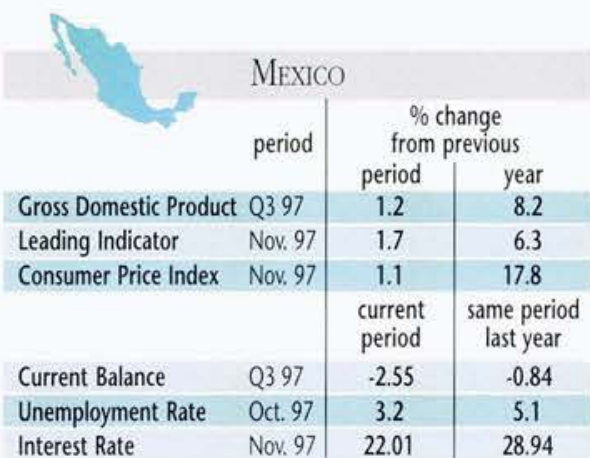
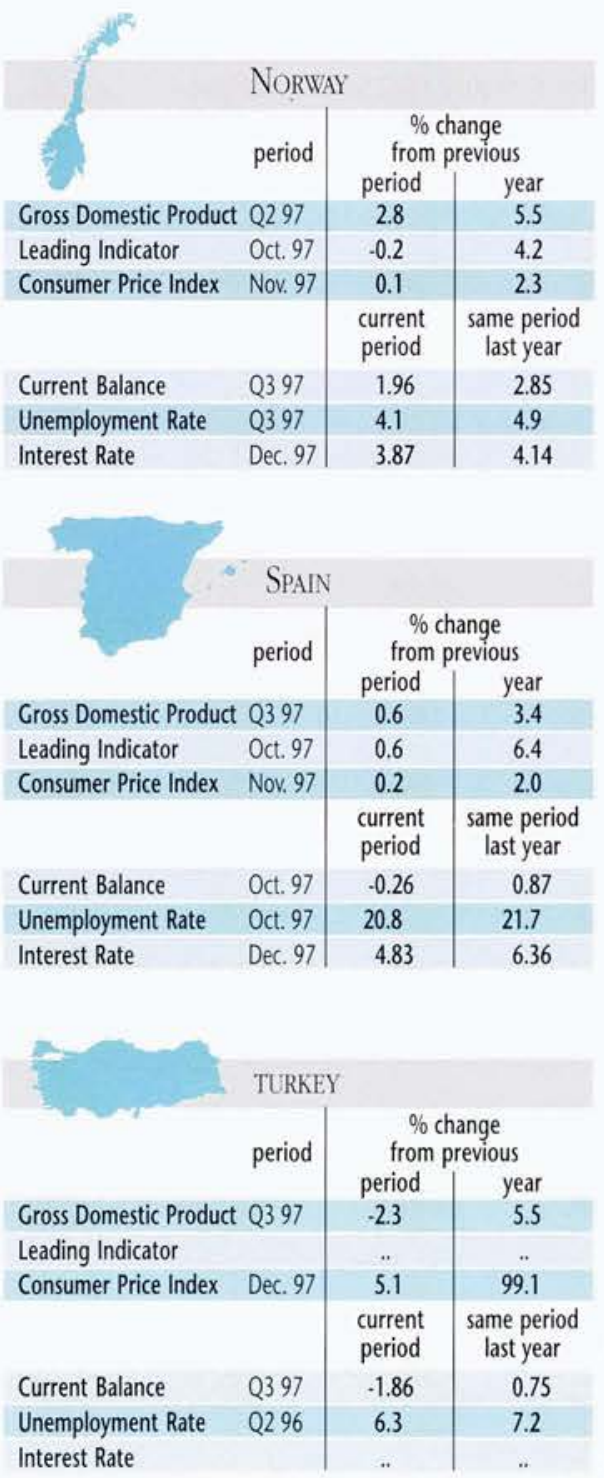
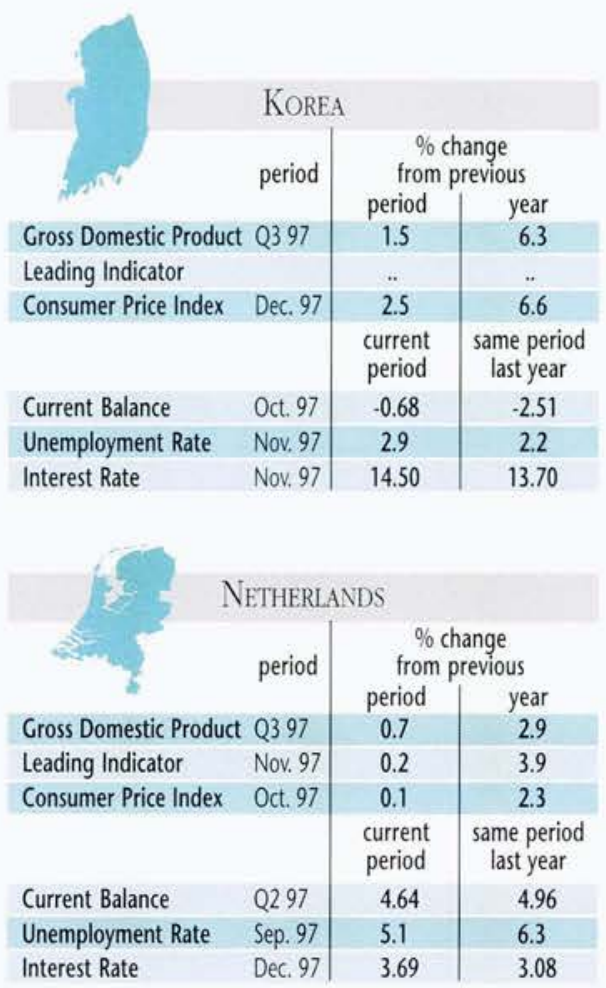

\begin{tabular}{ll|l|l} 
Interest Rate & Dec. 97 & 3.69 & 3.08 \\
\hline
\end{tabular}
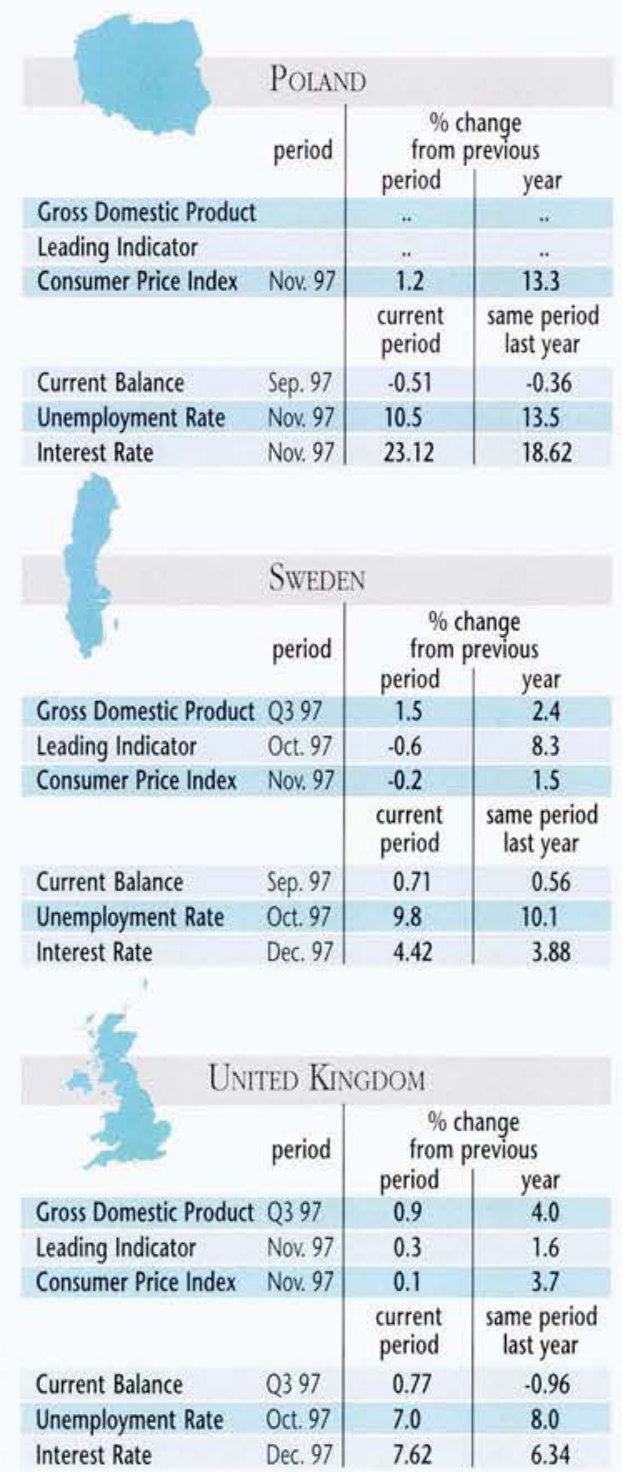
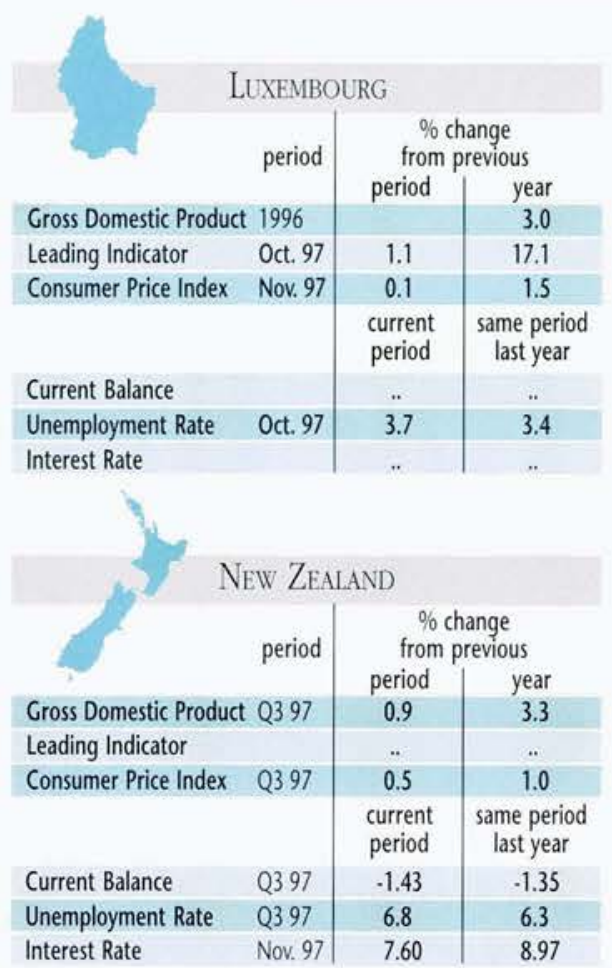

\begin{tabular}{l|l|l|l}
\hline Interest Rate & Nov. 97 & 7.60 & 8.97 \\
\hline
\end{tabular}
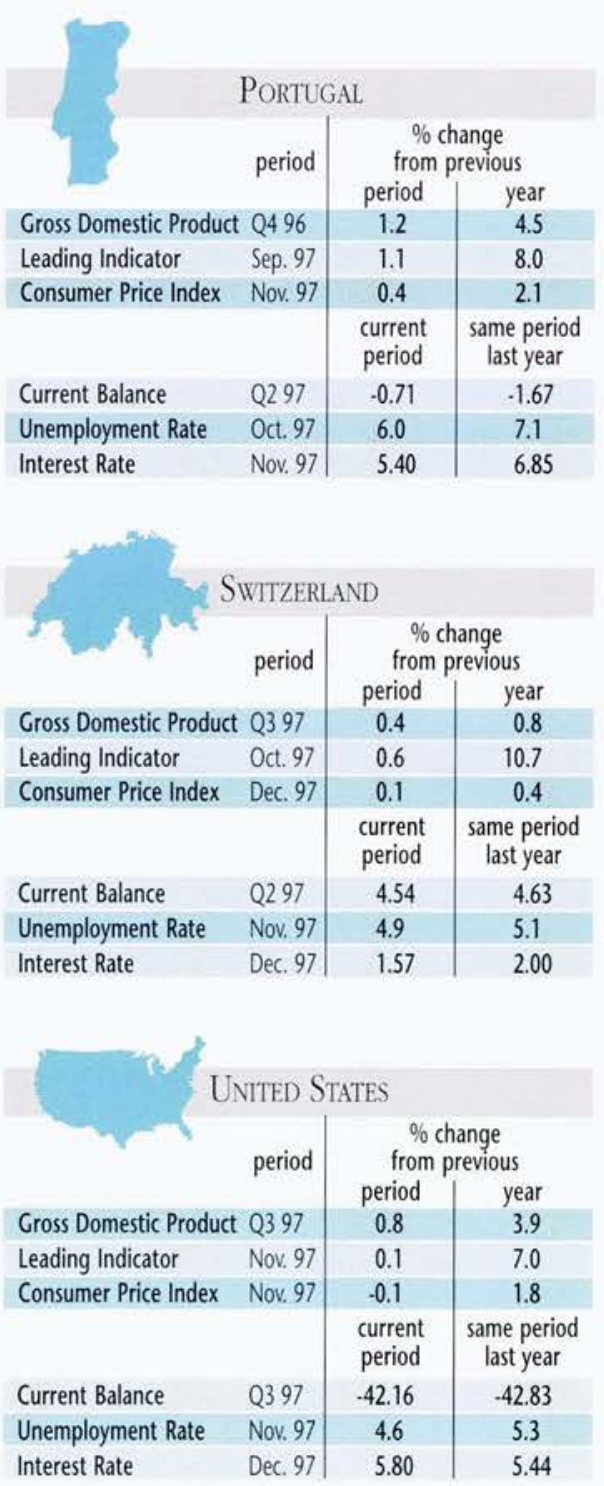


\section{The OECD Economic}

\section{Outlook}

\section{Highlights}

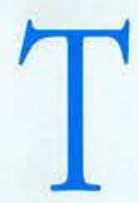

ensions in financial markets, which began in Thailand in mid-1997, spread to a number of other countries in East Asia, including Japan and Korea, in the following few months. At the same time, volatility in other OECD stock markets also increased considerably. Nevertheless, by 10 November - which corresponds to the cut-off date for information underlying the projections reported in the latest issue of the OECD Economic Outlook' developments since the summer did not appear to call for a fundamental reassessment of the relatively favourable outlook for the $\mathrm{OECD}$ area as a whole, although, compared with six months ago, they entailed important revisions to the distribution of output growth among the major $\mathrm{OECD}$ regions (Table 1, p. 51). Prospects for 1998-99 looked on average better for both the United States and Europe, but significantly worse for Japan.

Since then, however, financial problems have intensified in Japan and Korea. In the first instance, this has undoubtedly clouded the short-term outlook for Asia, but, more broadly, this may have increased the risks of spillover effects on other regions. Yet, provided appropriate actions are taken rapidly in the countries directly affected to deal with the fundamental causes of their current problems, in the absence of further significant shocks and with suitable international cooperation, developments during the last three weeks of November are unlikely to modify the overall picture substantially:

- in the United States and other countries where a prolonged phase of business upswing has been maintained with low inflation (Table 2, p. 52) and robust employment growth (Table 3, p. 54), the pace of activity, while decelerating somewhat, should remain close to potential rates

- in countries that might participate in the European Economic and Monetary Union, expansions appear increasingly solid, and they should gather pace over the next two years

- in Japan, where the expansion that started in 1996 faltered during 1997, the recovery has become increasingly fragile

- finally, in a number of other countries in East Asia, including Korea, prospects will be adversely affected by the financial crisis, implying in some cases much lower growth rates in the short run than those experienced over the past decade.

The main task facing governments in the countries most affected by financial turmoil is to ensure that adjustment policies to tackle problems at their roots be implemented as rapidly and effectively as possible. In Korea, difficulties in the banking sector have been exacerbated by the high indebtedness, as well as the deterioration in the cash-flow positions, of many large businesses, which to a large extent reflect fundamental governance problems. The immediate priority is for authorities to provide adequate liquidity to avoid systemic risks. Policy actions to speed up financial market liberalisation while strengthening prudential measures, restructure the corporate sector and improve governance structures are also essential to restore the soundness of the financial sector. Measures announced recently, as well as the Korean request for assistance from the International Monetary Fund, represent an important step in addressing these issues and, if reforms to make better use of market discipline are implemented rapidly, they should contribute to improve confidence and increase efficiency, and to prepare the grounds for the next stage of development of this dynamic economy.

\footnotetext{
1. OECD Economic Outlook, No. 62, OECD Publications, Paris, 1997.
} 
Table 1

Growth of Real GDP in the OECD Area

\begin{tabular}{|c|c|c|c|c|}
\hline & \multicolumn{4}{|c|}{$\begin{array}{l}\text { Change } \\
\text { from previous year }\end{array}$} \\
\hline & 1996 & 1997 & 1998 & 1999 \\
\hline United States & 2.8 & 3.8 & 2.7 & 1.9 \\
\hline Japan & 3.5 & 0.5 & 1.7 & 2.1 \\
\hline Germany & 1.4 & 2.4 & 3.0 & 2.9 \\
\hline France & 1.5 & 2.3 & 2.9 & 2.8 \\
\hline Italy & 0.7 & 1.3 & 2.1 & 2.6 \\
\hline United Kingdom & 2.3 & 3.4 & 2.2 & 2.1 \\
\hline Canada & 1.5 & 3.6 & 3.5 & 3.3 \\
\hline $\begin{array}{l}\text { Total of above } \\
7 \text { countries }\end{array}$ & 2.4 & 2.7 & 2.5 & 2.2 \\
\hline Australia & 3.4 & 2.9 & 3.6 & 3.7 \\
\hline Austria & 1.6 & 2.1 & 3.0 & 2.8 \\
\hline Belgium & 1.5 & 2.4 & 2.8 & 2.7 \\
\hline Czech Republic & 4.4 & 0.9 & 1.7 & 1.9 \\
\hline Denmark & 3.4 & 3.4 & 2.8 & 2.7 \\
\hline Finland & 3.3 & 4.6 & 3.9 & 3.2 \\
\hline Greece & 2.6 & 3.4 & 3.4 & 3.2 \\
\hline Hungary & 1.0 & 3.0 & 3.9 & 4.2 \\
\hline Iceland & 5.2 & 4.9 & 3.9 & 3.5 \\
\hline Ireland & 7.9 & 7.5 & 7.3 & 6.1 \\
\hline Korea & 7.1 & 6.2 & 5.5 & 6.0 \\
\hline Luxembourg & 3.0 & 3.6 & 3.7 & 3.6 \\
\hline Mexico & 5.1 & 6.7 & 5.4 & 5.0 \\
\hline Netherlands & 3.3 & 3.2 & 3.7 & 3.6 \\
\hline New Zealand & 2.1 & 1.9 & 3.7 & 3.2 \\
\hline Norway & 5.3 & 4.0 & 4.7 & 3.6 \\
\hline Poland & 6.1 & 5.6 & 5.4 & 5.2 \\
\hline Portugal & 3.0 & 3.4 & 3.7 & 3.2 \\
\hline Spain & 2.3 & 3.2 & 3.6 & 3.6 \\
\hline Sweden & 1.3 & 1.8 & 2.6 & 2.4 \\
\hline Switzerland & -0.2 & 0.5 & 1.7 & 2.0 \\
\hline Turkey & 7.2 & 6.3 & 5.3 & 5.0 \\
\hline $\begin{array}{l}\text { Total of above } \\
22 \text { countries }\end{array}$ & 3.9 & 4.1 & 4.1 & 4.0 \\
\hline Total OECD & 2.8 & 3.0 & 2.9 & 2.6 \\
\hline European Union & 1.7 & 2.6 & 2.8 & 2.8 \\
\hline
\end{tabular}

Figures in italics are provisional. Source: OECD restore confidence in the financial sector. This should require the use of government funds, as was the case in other OECD countries confronted with banking crises during the 1980 s and early 1990s. More has to be done, however. In particular, it will be important that efforts be made to increase transparency by strengthening accounting standards and by improving reporting and disclosure procedures.

Beyond policies to address problems in the financial sector, the accent in Japan must also be put on macroeconomic policies to secure the present recovery. The fragility of the expansion, which had been evident for several months before the financial turmoil affected Japan, was already calling for a more supportive stance of overall macro-economic conditions. The potential adverse consequences of more recent financial turbulence have now reinforced this requirement. On the monetary policy side, there is little or no scope for providing any further stimulus to domestic demand

In Japan, recent events have highlighted the underlying weaknesses of the financial sector. Already fragile balance sheet positions of some banks have been affected by falling equity prices, reinforcing the necessity that authorities act promptly and effectively to in the near term, in view of the historically low interest rates that prevail. Given the possibility that problems of banks' balance sheet may hinder the effectiveness of monetary policy, a continuation of the current easy stance is likely to be required for some time to come. On the other hand, some adjustment might be envisaged on the fiscal side. This, however, represents a particularly difficult challenge for Japan in the present situation. An ambitious approach to fiscal consolidation is required over the medium term, given the rapid aging of the population. Nevertheless, in the short run, more consideration should be given to possible ways to ease the fiscal stance without loosing sight of medium-term objectives. This might best be achieved through the implementation of budgetary measures that are also desirable on structural grounds. Reductions in taxation, to be seen as part of a more comprehensive fiscal reform, offset at a later stage by cuts in subsidies and other inefficient public expenditure, may provide an example of such measures. It is important that any tax cuts be seen as permanent; otherwise they may well be saved rather than reflected in higher domestic demand.

In continental Europe, the most pressing issue is to ensure a smooth transition process towards European Economic and Monetary Union (EMU) while also taking the necessary adjustments to make the monetary union fully successful, once it is established. At this stage, there remains a somewhat uncomfortable degree of divergence in the cyclical positions of countries that might participate in EMU, notably between the three largest economies, where the expansion has been lagging, and most smaller countries that are at a more advanced stage of the recovery. The common position to which short-term interest rates in countries of the prospective euro area will converge during the run-up to EMU may in some cases imply unwelcome adjustments and create potential tensions. A smooth transition will require an increasingly co-ordinated approach to setting monetary 
policy in these countries. Once EMU is established in early 1999, there will be a single monetary policy for the area as a whole which will be conducted, within the European System of Central Banks, by the new European Central Bank (ECB). It will thus be the responsibility of the ECB to ensure that the position of interest rates is appropriate for the area as a whole, even if conditions are not identical in all countries. The loss of autonomy of national monetary policy will restrain its use to address country-specific developments in the group of countries committed to joining in the first round of EMU. Moreover, exchange rate adjustments will no longer be possible within the area once EMU is established. Countries will therefore have to rely to the extent possible on fiscal policy to respond to adverse shocks that may affect their economies. In order to be able to do so, it will be essential for these countries to restore sound budget positions as rapidly as possible to allow for some flexibility within the obligations of the Stability and Growth Pact and to ensure longer-term fiscal stability.

A further important way to enhance the adjustment ability of countries aspiring to EMU is to pursue actively the structural reforms that are required to make labour and product markets more competitive and efficient. Many of these countries have already made some progress in the priority areas identified in the OECD Jobs Strategy, but much remains to be done in order to ensure the smooth absorption of potential shocks while avoiding increases in the inequality of wages and family incomes as well as poverty that risk hampering progress in the implementation of the strategy. Within the framework of the social welfare states that characterise European economies, firm actions across a broad front are still required: promotion of wage bargaining outcomes consistent with adequate profitability to stimulate investment and job creation; actions to reduce segmentation of labour markets into 'insiders' and 'outsiders'; expanding the scope of enterprises to negotiate the flexible working arrangements required to strengthen competitiveness; careful attention to the parameters of tax-benefit systems to assure adequate incentives to work, while protecting those who are unable to do so; active policies to improve the labour-market position of the least skilled and long-term unemployed; more effective education and training policies; and liberalisation of sectors where competition remains inadequate to promote efficiency and stimulate entrepreneurship. Such a broad programme, the main lines of which were developed in the OECD Jobs Strategy, can significantly improve employment outcomes without posing a threat to the social consensus and equity objectives. To meet these goals, it is important that care be taken in the design and implementation of specific schemes and policies aimed at promoting job creation and reducing inequalities, to avoid disemployment effects and excessive rigidities, as well as increases in labour costs.

$\%$ aggregate.

Source: OECD
Table 2

\section{Private Consumption Deflators in the OECD Area}

\begin{tabular}{|c|c|c|c|c|}
\hline & \multicolumn{4}{|c|}{$\begin{array}{l}\text { Change } \\
\text { from previous year }\end{array}$} \\
\hline & 1996 & 1997 & 1998 & 1999 \\
\hline United States & 2.4 & 2.1 & 2.0 & 2.3 \\
\hline lapan & 0.2 & 1.7 & 1.0 & 0.6 \\
\hline Germany & 2.0 & 2.0 & 1.9 & 1.9 \\
\hline France & 1.8 & 1.3 & 1.4 & 1.5 \\
\hline Italy & 4.5 & 2.2 & 2.4 & 2.2 \\
\hline United Kingdom & 2.6 & 2.0 & 2.3 & 2.6 \\
\hline Canada & 1.2 & 1.5 & 1.4 & 1.6 \\
\hline $\begin{array}{l}\text { Average of above } \\
7 \text { countries }\end{array}$ & 2.0 & 1.9 & 1.8 & 1.9 \\
\hline Australia & 2.0 & 1.5 & 2.0 & 2.1 \\
\hline Austria & 2.5 & 1.5 & 1.5 & 1.6 \\
\hline Belgium & 2.3 & 1.7 & 1.6 & 1.6 \\
\hline Czech Republic & 8.8 & 8.8 & 9.5 & 9.0 \\
\hline Denmark & 2.6 & 2.3 & 2.6 & 2.9 \\
\hline Finland & 1.6 & 1.5 & 2.2 & 2.5 \\
\hline Greece & 8.5 & 5.8 & 4.5 & 3.5 \\
\hline Hungary & 22.7 & 17.8 & 14.3 & 12.0 \\
\hline Iceland & 2.6 & 1.8 & 3.1 & 3.6 \\
\hline Ireland & 1.1 & 0.9 & 2.2 & 2.4 \\
\hline Korea & 6.0 & 4.5 & 4.8 & 4.6 \\
\hline Luxembourg & 1.4 & 1.4 & 1.5 & 1.5 \\
\hline Mexico & 34.0 & 20.9 & 13.7 & 11.0 \\
\hline Netherlands & 1.4 & 2.0 & 2.3 & 2.4 \\
\hline New Zealand & 2.5 & 1.5 & 1.5 & 2.0 \\
\hline Norway & 1.1 & 2.6 & 2.8 & 3.1 \\
\hline Poland & 19.9 & 15.1 & 11.5 & 9.3 \\
\hline Portugal & 3.2 & 2.3 & 2.2 & 2.1 \\
\hline Spain & 3.4 & 2.0 & 2.4 & 2.4 \\
\hline Sweden & 1.2 & 2.1 & 2.2 & 2.2 \\
\hline Switzerland & 1.1 & 0.6 & 0.9 & 1.4 \\
\hline Turkey & 74.1 & 82.0 & 70.0 & 60.0 \\
\hline $\begin{array}{l}\text { Average of above } \\
22 \text { countries }\end{array}$ & 13.8 & 11.9 & 9.9 & 8.7 \\
\hline Average OECD & 4.6 & 4.1 & 3.6 & 3.4 \\
\hline $\begin{array}{l}\text { Average OECD } \\
\text { less high-inflation } \\
\text { countries' }\end{array}$ & 2.2 & 2.0 & 1.9 & 2.0 \\
\hline European Union & 2.7 & 2.0 & 2.1 & 2.1 \\
\hline
\end{tabular}

Figures in italics are provisional.

1. Countries which have had $10 \%$ or more inflation in terms of GDP deflator on average during the 1990s on the basis of historical data. The Czech Republic, Greece, Hungary, Mexico, Poland and Turkey are thus excluded from the

The focus of the policy debate in several countries where growth has been robust and expansions are becoming mature, has continued on page 54 


\section{The Trade-related Impact of Financial Turbulence in South-east Asia on OECD Countries}

Trade linkages between OECD member countries and the South-east Asian economies affected by financial turbulence since the middle of 1997 are strong, since these economies are both important export markets for OECD countries and important competitors in markets in the OECD area itself. The combination of the financial turbulence itself and subsequent policy tightening to reduce domestic demand in the affected economies in order to facilitate external adjustment will adversely affect export-market growth for OECD countries. Furthermore, exchange-rate depreciation will improve the competitiveness of the affected economies, further discouraging imports and increasing export volumes (even if the countries are largely price-takers, as increased profitability encourages higher production). A simulation exercise was conducted using the OECD's 'Interlink' model to estimate the impact, via trade linkages only, of these developments on OECD countries.

The non-OECD countries most directly affected by the turbulence are Indonesia, Malaysia, the Philippines and Thailand and, to a lesser extent, Chinese Taipei, Singapore and Hong Kong, China. The impact on non-OECD Asia as a whole of developments which had occurred by 10 November 1997, the cut-off date for information reflected in the projections, is assumed to be the following: import volume growth of goods and services is lower by 3 percentage points in 1997 and 3.5 percentage points in 1998; manufactures and non factor services export volume growth is higher by 1.5 percentage points in 1997 and by 2.5 percentage points in 1998 ; export prices of manufactures in dollar terms are lower by 1.5 percentage points in 1997 and by an additional 2 percentage points in 1998.

Assuming that the reduction of imports and the increase of exports in these countries are spread between the OECD and the rest of the world in proportion to the underlying trade flows, the impact on OECD exports and imports would be about US $\$ 25$ billion per year $(0.5 \%$ of total OECD exports of goods and services) and $\$ 15$ billion per year $(0.3 \%$ of total OECD imports of goods and services), respectively.

Potential Macro-economic Impact of the South-east Asian Financial Turbulence on the OECD Area'

percentage deviation from baseline

\begin{tabular}{|l|cc|cc|cc|} 
& \multicolumn{2}{c|}{ Real GDP } & \multicolumn{2}{c|}{ Net Exports } & \multicolumn{2}{c|}{ Inflation $^{3}$} \\
& 1997 & 1998 & 1997 & 1998 & 1997 & 1998 \\
\hline United States & -0.3 & -0.7 & -0.1 & -0.3 & 0.0 & -0.3 \\
Japan & -0.6 & -1.4 & -0.2 & -0.5 & 0.0 & -0.9 \\
European Union & -0.3 & -0.8 & -0.2 & -0.5 & 0.0 & -0.3 \\
Korea, Australia, & & & & & & \\
$\quad$ New Zealand & -0.5 & -1.4 & -0.3 & -0.7 & -0.1 & -0.5 \\
Total OECD & -0.3 & -0.9 & -0.2 & -0.5 & 0.0 & -0.5
\end{tabular}

1. Nominal exchange rates and real interest rates in OECD countries are assumed to be unchanged.

2. Goods and services; contribution to the change in GDP

in percentage points.

3. Change in the private consumption deflator. Source: OECD

The simulation assumes nominal exchange rates and real interest rates to be unchanged, and thus provides an estimate of the ex ante effect of the shock that the turbulence implies before taking account of any policy response in OECD countries. Since it is likely that monetary policies would respond and, if necessary, exchange rates would adjust, an ex post measure of the effects of the crisis would give smaller effects on output, by amounts that could vary across countries, than the simulation suggests.

The table reports the potential impact of these developments on GDP, inflation and the contribution of net exports to GDP growth in selected OECD countries and regions on the assumptions noted above. The results suggest a potential impact on the volume of output in the OECD area of nearly $1 \%$ by 1998 . It also indicates that the impact is potentially twice as large in Japan, and the other OECD countries nearby (Korea, Australia and New Zealand) as it is in the United States and the European Union.

These findings should be interpreted with much caution, mainly because of the difficulty of analysing the direct effects of the crisis in the Asian countries themselves. There are two main uncertainties. First, the actual extent of the internal adjustment measures implemented in the countries affected by the crisis in a context of large falls of equity prices and subsequent negative wealth effects is uncertain. Second, the repercussions on the area's trade of the large changes in relative exchange rates, and particularly the speed and magnitude of the adjustments of trade flows to those changes, are subject to a large degree of uncertainty insofar as a part of imports and exports (energy and primary products) is relatively insensitive in the short term to price changes. 
increasingly been the extent to which excess demand pressures are already emerging or are an imminent risk. Macro-economic policy priorities in this group of countries, which includes the United States, the United Kingdom, Canada and some smaller countries, vary in terms of the immediacy of the importance of restraint and the reliance that should be placed on monetary policy. But all must be vigilant to the possibility that inflation could soon rise. The difficult judgement that must be made in these countries concerns the extent of spare capacity in circumstances where historical relationships appear to offer uncertain guidance as to the effects of technological change, structural reform and increasing internal competition in product markets. These questions have been widely debated in the United States, where the economy has been growing at rates above most estimates of the growth of potential output for some time and the unemployment rate has fallen to figures below

Table 3 most current estimates of the structural rate of unemployment. While in the past such degrees of activity have been associated with a rise in inflation, this has not, as yet, been the case, leading some observers to conclude
Unemployment in the OECD Area ${ }^{\prime}$

\begin{tabular}{|c|c|c|c|c|c|c|}
\hline & \multirow{2}{*}{$\begin{array}{c}\text { Thousands } \\
1994\end{array}$} & \multicolumn{4}{|c|}{$\%$ of labour force } & \multirow{2}{*}{ in Asia and volatility in equity prices slow } \\
\hline & & 1996 & 1997 & 1998 & 1999 & \\
\hline United States? & 7,973 & 5.4 & 5.0 & 4.7 & 5.0 & te pace or acuivity to a more \\
\hline lapan & 1,919 & 3.4 & 3.4 & 3.4 & 3.3 & $\mathrm{r}$ \\
\hline Germany & 3,698 & 10.3 & 11.4 & 11.4 & 10.9 & $\mathrm{~d}$ be both pr \\
\hline
\end{tabular}

To sum up, financial turbulence has increased uncertainty and, in the absence of prompt and adequate policy actions to restore confidence, it could create serious economic difficulties. However, if authorities in the countries directly affected take this opportunity to implement policies that, in some cases, were long called for, there would be no basis for any wholesale revision of the relatively favourable near-term economic prospects embodied in the OECD's present projections. Nevertheless, increased uncertainty, and the significant adjustments in trade and financial flows that are likely to follow from recent developments, serve to emphasise the importance for all countries of taking the actions necessary to increase the adaptability of their economies and their resilience to unpredictable shocks. Domestically, the reform agenda in this regard remains substantial for most OECD countries. Internationally, there is a heightened premium on close co-operation both to contain undesirable financial spillovers and to assure that the foundations of the international economy are not eroded by short-sighted protectionist responses.
Figures in italics are provisional.

1. Commonly used definitions.

2. Break in series from January 1994

3. Figures based on the national survey of urban employment.

4. Rebased.

5. Important revisions to data.

Source: OECD 


\section{Industrial Performance and Competitiveness in an Era of Clobalisation and Technological Change}

\section{Meeting of the OECD Industry Committee at Ministerial Level}

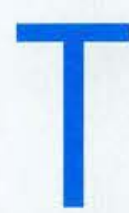

he OECD Industry Committee is meeting at ministerial level on 3-4 February 1998. The meeting will be chaired by Margaret Beckett, United Kingdom. A Business Symposium is being held before the meeting, and there is a joint session of ministers and business representatives, which will also look at how to strengthen government-industry dialogue.

\section{The Issues}

Globalisation, increased competition and rapid technological change continually alter the environment in which industry and business operate. Opportunities for growth have been improved by adoption of sound macro-economic policies, balanced public finances and monetary stability, and widespread liberalisation of trade and investment.

But economic performance has diverged, strengthening perceptions that further structural reforms are necessary in many countries. There is also recurring unemployment and/or increasing income inequality, calling for comprehensive responses beyond macro-economic policy. Prosperity, job-creation and the ability to address the range of social issues facing $O E C D$ countries require strong business performance. More than ever, firms must be able to deal with continuous change and build assets for the future.

But there are barriers to achieving these goals: short-time horizons affecting investment and business $R \& D$; difficulties in financing innovation and investments in new areas; insufficient skills and adaptability of the work force; barriers to market access, retarding the development of competitive markets; and a regulatory environment inhibiting business growth and new entry. Some of these barriers are particularly important for small and medium-sized enterprises (SMES) in a globalised, technology-driven environment.

\section{New Policy Directions}

The ministerial meeting is focusing on improving the business environment to underpin investment, sus- tainable growth and employment. A business environment which promotes competitiveness and opportunity for all is a necessary complement to sound macro-economic conditions and an open multilateral system. This will foster entrepreneurship and encourage firms and individuals to exploit new opportunities and move into high value-added activities.

The meeting is examining reforms, initiatives and policy co-ordination to enable firms to become more innovative, flexible and competitive and increase their productivity. Broad policy strategies emphasise:

- an open, international orientation

- enhancing development of the knowledge-based economy

- efficient design and delivery of policies.

Elements in these strategies vary across countries, but often include improving the functioning of markets and strengthening the business environment to enable firms to deal with continuous change and build future assets; removing impediments to investment in technology, human resources, and other intangible assets; securing an appropriate science and technology base and protection of intellectual property rights; adopting a consistent approach to regulatory reform and a rigorous competition policy; strengthening the institutional and physical infrastructure for enterprises (capital markets, corporate governance, efficient business services, communications and transport).

Special action is also required in many OECD countries to foster entrepreneurship and enhance the growth and job-creation potential of SMEs by boosting technological and managerial capabilities and skills, improving the functioning of capital markets, minimising regulatory burdens, and widening participation in the international economy (through electronic commerce, for example).

In order to achieve these goals, it is crucial to make policy design and implementation more effective. Although governments must be selective and prioritise what they can do, it is important to address the following areas: designing policy frameworks with clear rationales and objectives based on comprehensive consideration of business opportunities, difficulties and requirements; determining where incentives can stimulate businesses to invest in their own future; improving co-ordination; simplifying policy delivery; systematically evaluating policies and programmes and disseminating best practice to strengthen policy effectiveness; as well as increasing efforts to have policies agreed and accepted by the labour force and the public at large.

Co-operation and exchange of experience can help policy enhance the business environment and asset creation. There is a continuing requirement for international analyses and indicators of major factors affecting business performance, the better to inform the policy debate.

Moreover, structural changes associated with globalisation and technological change are often difficult to absorb for some segments of the economy and society. Innovative non-market-distorting policy responses are necessary to ensure that benefits are fully realised and widely shared.

Based on these policy directions, ministers may also discuss co-operation on:

- globalisation and policies to realise more fully the benefits from it

- regulatory reform and the creation and develop. ment of technology-based and innovative SMES

- intangible assets, organisational change in the firm, human resources and firm competitiveness

- the growth of business services and electronic commerce and their impacts on competitiveness

- benchmarking factors affecting business performance

- policy appraisal and evaluation.

E-mail: dsti.contact@oecd.org 


\section{Publications November-December 1997}

Order Form at the end of the issue

\section{Agriculture, Fisheries, Food}

National Policies and Agricultural Trade

\section{Mexico}

November 1997

Mexico's agricultural policies have been radically reformed in recent years as part of the opening up and deregulation of the economy. This provides a challenge for Mexico's agro-food sector to improve its efficiency and competitiveness. But it also offers opportunities to help the agricultural sector and the rural economy to adjust to market conditions, raise productivity, and alleviate rural poverty.

Drawing on the OECD's well-established method of calculating support from agricultural policies using Producer and Consumer Subsidy Equivalents, this study is one of the most comprehensive analyses and assessments of the rapidly evolving developments in Mexican agricultural policies. (51 97 (09) 1 P) ISBN $92-64-15486-8,250 \mathrm{pp}$.

FF290 L5557 DM85 \$37 Y6,100

\section{Competition}

and Consumer Policy

\section{OECD Proceedings}

The Role of the Competition Agency in Regulatory Reform November 1997

Deregulation alone does not necessarily lead to competition. Competition agencies can actively contribute to eliminating constraints on competition. especially when dealing with partial deregulation, violations of law, and maintenance of long-standing noncompetitive habits. If the point of deregulation is to promote competitive markets, competition agencies seem ideally suited to lead the process.

A Workshop, held in Tokyo in December 1996, brought together Com- petition enforcement experts from France, Italy, Korea and the United States as well as Japanese officials to bring experiences of other countries competition agencies to bear on the Japan Fair Trade Commission. This publication gives an account of these frank and fruitful exchanges of views. advocating procompetitive deregulation coupled with efficient regulatory reform. (24 9705 1 P) ISBN 92-64-15692-5,940pFFE5 LSS11 DM19 \$7 Y1,250

\section{Development and Aid}

Development Co-operation Reviews

France

No. 21

November $199^{7}$

France, the second largest donor of aid after Japan, is a major actor in international development co-operation. The DAC review of French policy notes that France does a great deal, at all levels, to keep developing countries' issues and problems, such as indebtedness, high on the international agenda.

In its triennial review of France's aid policies and programmes, held on 14 March 1997, the OECD Development Assistance Committee (DAC) showed interest in the progress of the agenda of reforms currently underway in the French programme of development cooperation. More particularly, the Committee discussed a number of questions on French policy and aid management which will be followed-up at the next Peer Review of France's programme:

- the benefits of clearly linking France's overarching policy for development assistance with its operational programmes

- the continuing importance of design, appraisal, monitoring and evaluation in maximising the impact of French development co-operation

- the similar importance of an ambitious strategy of assistance in the social sectors, especially relating to gender equality, family planning, education and health care.
1. The OECD Report on Regulatory Reform Synthesis

See The OECD Observer. No. 206, June/July 1997

(42 9705 1) ISBN 92-64-15556-2, 65pp.

FF35 US\$7 DM10 \$5 ¥750

2. Historical Statistics $\mathbf{1 9 6 0 - 9 5}$

1997 Edition

(30 97 04 3) ISBN 92-64-05531-2, 180pp

FF195 USS38 DM57 $\$ 25 \quad ¥ 4,100$

3. Activities of Foreign Affiliates in $\mathrm{OECD}$ Countries 1985-94

Statistical Data

1997 Edition

(92 9706 3) ISBN 92-64-05522-3, 273pp.

FF350 US\$69 DM103 \&45 $\quad 77,350$

4. Natural Gas Information 1996

(61 9722 1) ISBN 92-64-15592-9, 512pp.

FF585 US\$115 DM170 \$76 ¥12,300

5. Agricultural Policies in Transition Economies Monitoring and Evaluation 1997

(14 9708 1) ISBN 92-64-15587-2, 200pp.

FF190 US\$37 DM56 $\$ 25 ¥ 4,000$

6. OECD Environmental Data

Compendium 1997

(97 9719 3) ISBN 92-64-05539-8, 300pp.

FF260 US\$50 DM76 \$34 \$5.500

7. Consumer Policy in OECD Countries 1995 1997 Edition

(24 9703 1) ISBN $92-64-15604-6,148 \mathrm{pp}$

FF175 US\$34 DM50 $₫ 23 \quad ¥ 3,700$

8. OECD Environmental Performance Reviews

Finland

(9797 16 1) ISBN 92-64-15593-7, 145pp.

FF180 US\$35 DM55 \$23 ¥4.140

9. Entrepreneurship and SMEs in Transition Economies The Visegrad Conference

(14 9707 1) ISBN 92-64-15611-9, 200pp.

FF140 US\$28 DM40 §18 $¥ 2,950$

10. Labour Force Statistics 1976-96 1997 Edition

(30 9705 3) ISBN $92-64-05536-3,530 \mathrm{pp}$

FF495 US\$97 DM145 $\{64 ¥ 10,400$ 
Development co-operation policy reviews in 1998 are planned for the following DAC Members: Belgium Canada, the Netherlands, Portugal and the United Kingdom (439709 1 P) ISBN 92-64-15517-1, 8ipp FFo tSS18 DM26 \$12 \$1,900

\section{Economy}

OECD Economic Surveys

United States 1996/1997

1997 Edition

November 1997

See The OECD Observer, No. 209 ,

December 1997/January 1998.

(10 97021 P) ISBN 92-64-15-28-0, 234pp.

FF125 USS25 DM40 \$15 \$2,900

Also available as an Electronic Book.

Japan 1996/1997

1997 Edition

November 1997

see The OECD Observer, No. 209 ,

December 1997/January 1998.

(10 97 03 I P) ISBN 92-64-15429-9, 204pp.

FF125 US\$25 DM40 \$15 \$2.900

Also available as an Electronic Book.

\section{Russian Federation \\ 1996/1997}

1997 Edition

December 1997

See pp. $45-47$ of this OECD Observer

(10 9737 1 P) ISBN 92-64-15981-9, 290pp.

FF125 US\$25 DM40 \$15 Y2,900

Also available as an Electronic Book. 1998 Subscription:

ISSN 0376-6438

FF1,800 USS385 DM550 $\$ 210 \$ 38,500$

\section{The World in 2020}

Towards a New Global Age

November 1997

We stand on the threshold of a New Global Age. All countries now have the potential to become active players in the global economy. By 2020 there could be dramatic shifts in global economic weight. What will the world economy look like in 2020? How can we ensure increased and better distribution of wealth? This publication based on a wide spectrum of OECD work takes us to the world of 2020 covering such closely linked fields as trade, investment, taxation, social stability and the environment. The challenges awaiting us at the dawn of the 21st century can thus be assessed more clearly.

Two visions of the world economy in 2020 are presented. The first scenario suggests a continuation of current trends and leads to only modest growth, limiting the potential for human progress. The second provides a more optimistic outlook based on an acceleration of policy reform, with the promise of more human well-being, better integration of developing countries, enhanced international security and a reduction in poverty world-wide. This New Global Age will not materialise automatically Significant efforts will have to be made to secure the stability of macro-economic policy, facilitate large-scale structural reform and define innovative approaches. The projections under this optimistic scenario are not enough: they must lay the foundation for an even more ambitious vision so that a new age of global prosperity can be fully realised.

(039708 1 P) ISBN 92-64-15627-5, 136pp. FF85 ISS17 DN25 जा भा 1800

\section{Main Economic Indicators \\ Volume 11 \\ November 1997 \\ (31 97113 P) 1SBN 92-64-05226-7, 228pp. bilingua \\ FF150 LSS29 DM45 \$19 \$3,400 \\ Also available on CD-ROM. \\ 1998 Subscription: \\ [SSN 0474-5523 \\ FF25,250 USS 4,590 DN7, $450 \$ 3,200 \times 532,800$}

Monthly Statistics of Foreign

Trade

November 1997 - Series A

November 1997

(3297 11 3 P) ISBN 92-64-05210-0, 128pp. bilinguil

FF110 USS20 DM30 \$12 Y2,400

Quarterly National Accounts Third Quarter 1997

November 1997

(36 97 033 P) ISBN 92-64-05214-3, 270pp. bilingual

FF130 US\$25 DM38 \$17 \$3.000

\section{Economies in Transition}

Short-Term Economic

\section{Indicators}

Fourth Quarter 1997

November 1997

This quarterly publication complements the OECD Main Economic Indicators. It presents a wide range of monthly, quarterly and annual economic indicators covering such topics as industrial production, business surveys, construction, employment, earnings, prices, domestic and foreign finance, interest rates and domestic and foreign trade for 18 transition countries: Armenia, Azerbaijan, Belarus, Bulgaria, Estonia, Kazakstan, Kyrgyz Republic, Latvia,
Lithuania, Moldova, Romania, Russian Federation, Slovak Republic, Slovenia, Tajikistan, Turkmenistan, Ukraine and Uzbekistan

(07 97043 P) ISBN 92-64-05248-8, 145pp. bilingual

FF100 US520 DM28 $₫ 13 \quad ¥ 2,200$

Also available on diskette

1998 Subscription:

ISSN 1019-9820

FF2,375 USS455 DN700 $\$ 300$ Y50,000

\section{Education}

\section{Literacy Skills \\ for the Knowledge Society Further Results \\ from the International Adult Literacy Survey \\ November 1997}

This second comparative report from the International Adult Literacy Survey presents new findings for 12 OECD countries. Low literacy is a much larger problem than previously assumed in every country surveyed: from one-quarter to over one-half of the adult population fail to reach the threshold level of performance considered as a suitable minimum skill level for coping with the demands of modern life and work.

There are significant differences among member countries in how literacy skills are distributed in the population. In some, performance is skewed towards exceptional achievement among a minority in the work force; in others skills are more evenly distributed, with less people on the lowest level. Differences in the skill profiles of nations have implications for continued economic prosperity, democracy and social cohesion because jobs in knowledge societies require high levels of skills.

Improving the literacy skills of a large number of adults is a high priority everywhere, but how can this be done? This report suggests that active and daily practice at work and at home is the key. Employers in particular have a large role to play, because of the importance of the work environment to much adult learning

(81 97071 P) ISBN 92-64-15624-0, 200pp. FF180 US\$30 DM53 \$18 Y3,500

\section{PEB Exchange}

No. 32

November 1997

(889732 1 P) ISBN 92-64-15390-X, 24pp.

FF60 USS15 DM18 \&8 Y1,400
Indicators of Education Systems

Education at a Glance 1997 OECD Indicators

November 1997

Across OECD countries, governments are seeking policies that make education more effective while searching for additional resources to meet the increasing demand for education. The OECD education indicators enable countries to see themselves in the light of other countries' performance. They reflect both on the human and financial resources invested in education and on the returns on these investments.

The 1997 edition of Education at a Glance - OECD Indicators provides a richer and more comparable and up-todate array of indicators than ever before. The 41 indicators represent the consensus of professional thinking on how to measure the current state of education internationally. The thematic organisation of the volume and the background information accompanying the tables and charts make this publication a valuable resource for anyone interested in analysing education systems across countries.

The OECD education indicators are published simultaneously with Education Policy Analysis 1997, which takes up selected themes of key importance for governments.

The data underlying the OECD education indicators are accessible via the Internet (URL http://www.oecd.org/els stats/els_stat.htm).

(969704 1 P) ISBN 92-64-15622-4, 345pp. FF260 USS:13 DN777 \$27 Y5,100

\section{Education Policy Analysis} 1997

November 1997

This is the companion volume to the OECD's 1997 collection of international education indicators - Education at a Glance - OECD Indicators. It aims to deepen the analysis of current policy issues and facilitate interpretation of data, using selected indicators of particular relevance to the policy questions under examination.

The five chapters analyse topics of concern to a broad audience: costs and expenditures, the stock of human capital available to OECD economies, the literacy performance of adults in 12 countries, educational failure and success, and the efficiency and effectiveness of tertiary institutions in responding to new interests and needs of learners. (9697 051 P) ISBN 92-64-15682-8, 80pp. FF50 US58 DM15 \&5 ¥1,000 


\section{Energy}

International Energy Agency (IEA)

\section{International Coal Trade Market Operation \\ and Prospects \\ November $199^{7}$}

The international coal market has developed over the last 25 years to a mature, stable market, largely free of government involvement. It is evident, however, that while the coal market is considered widely to be reliable and secure, there is only limited understanding of the way in which the market operates. Understanding energy market mechanisms is fundamental to encourage confidence in the continuing performance of liberalised markets. This publication seeks to address this requirement by providing a brief descriptive analysis of the operation of the coal market.

The report draws attention to the considerable changes that have been experienced to date in the market, where freely operating market mechanisms have coped well. Further change is on the horizon. Demand for coal in Europe is stagnating while growing rapidly in Asia. The once dominant European market remains the region where price is formed but the Asian market is growing rapidly and becoming more flexible. Increasing competition for market share, low margins and pressure on utilities to reduce costs as electricity markets are liberalised, will continue to stimulate productivity improvement and may lead to innovations in marketing to cope with stable real prices, and high transport and transaction costs. (61 97301 P) ISBN 92-64-15667-4, 160pp FF220 USS43 DN64 228 Y4.650

\section{$\mathrm{CO}_{2}$ Emissions from Fuel Combustion A New Basis for Comparing Emissions of a Major Greenhouse Gas \\ 1997 Edition \\ November 1997}

In order for nations to tackle the problem of climate change, they need accurate data on greenhouse-gas emissions.

This publication provides a new basis for comparative analysis of $\mathrm{CO}_{2}$ emissions from fuel combustion, a major source of anthropogenic emissions. The data in this book are designed to assist in understanding the evolution of these emissions from 1972 to 1995 on a country, regional and world-wide basis. They should help in preparation for and in follow-up to the Third Conference of the Parties (COP-3), meeting under the Climate Convention in Kyoto in December. 1997.

Emissions were calculated using IEA energy data bases and the methods and emissions factors from the Revised 1996 IPCC Guidelines for National Greenhouse Gas Inventories.

(61 9732 1 P) ISBN 92-64-15676-3, 448pp

FF590 USS116 DM173 \$776 Y12,400

Also available on diskette:

(61 97321 D) ISBN 92-64-15159-1

FF2,500 US\$410 DM740 \$250 ₹49,100

\section{Key Issues in Developing Renewables}

November 1997

Renewable energy sources make important contributions to our energy needs. But they could contribute even more. International enthusiasm for the use of renewable energy technologies reflects their major environmental benefits, particularly in reducing $\mathrm{CO}_{2}$ emissions. But to fulfil the substantial role expected of renewable technologies in the future, this enthusiasm should be harnessed to specific and realistic action to encourage and facilitate their widespread deployment.

This report identifies the main issues in the further development and deployment of renewable energy technologies and the actions required to overcome institutional and market barriers.

(61 97371 P) ISBN 92-64-16009-4, 72pp.

FF100 US516 DM30 \$10 \$1,950

\section{Energy Policies of IEA Countries}

\section{Energy Policies of the Slovak Republic 1997}

November 1997

This IEA report provides a comprehensive in-depth review and assessment of energy policies and market conditions in the Slovak Republic, including recommendations to assist the Government in its continued efforts to modernise the country's energy sector.

As a follow-up to the 1992 IEA Survey of Energy Policies of the Czech and Slovak Federal Republic, the study pays particular attention to energy developments since the country gained independence in 1993. The report highlights areas which require urgent action: reforming energy prices, improving the legal and regulatory environment and enhancing energy efficiency. Slovakia's high dependence on imports - particularly oil, gas and nuclear fuel - calls for decisive measures to diversify supply sources and improve energy security.

The report contains detailed information on the structure of energy industries, investment requirements - especially in the gas and electricity sectors energy demand and supply, and issues related to energy and the environment, including nuclear safety.

(61 9726 I P) ISBN 92-64-15621-6, 150pp.

FF 225 ISS44 DM66 529 Y 4,750

\section{Environment}

\section{Climate Change \\ Mobilising Global Effort \\ November 1997}

Partnerships for technology co-operation, partnerships with local governments and strategies for communication are necessary elements in government strategies to respond to climate change. These themes emerged from the 1997 OECD Forum on Climate Change. Opening the Forum to representatives of the financial community, the insurance industry and the 'green business sector as well as to local government, environmental non-governmental organisations, and developing country experts, brought fresh thinking to the forefront in the lead up to Kyoto and COP-3. This book contains a selection of papers from the meeting and the 'rapporteur's' report. Its contents help to define the role of governments and begin to address how best to mobilise global effort to respond to climate change.

(979721 1 P) ISBN 92-64-15675-5, 136pp. FF195 USS38 DM57 \&25 Y4,100

\section{Reforming Energy and Transport Subsidies Environmental and Economic Implications \\ November 1997}

Reforming subsidies to polluting activities can benefit both the environment and the economy. While some recent studies may have overestimated these benefits, reforming policies that encourage environmentally damaging activities is a first step towards environment policy objectives. But to what extent is it worth reforming energy and transport subsidies?

This unique set of case studies shows that reforming supports to coal, electricity and transport could offer substantial environmental benefits in some countries. In others, the environmental improvement would be minimal. The social, economic and environmental outcome of reforms depends heavily on national and local circumstances and on the way reforms are implemented.

This report identifies key types of support whose reform might benefit the environment, pointing out some of the pitfalls of ill-considered reforms. It also suggests some ways in which national governments and the international community might proceed. bringing together environmental, social and economic policy agendas. (97 97 22 1 P) ISBN 92-64-15681-X, 168pp. FF190 US537 DM56 \$25 \$4,000

\section{OECD Proceedings}

\section{Towards Sustainable Transportation}

November 1997

The past fifty years have seen an exponential growth in the mobility of both people and goods. This growth, while contributing to social and economic advances, is now increasingly eroding some of the very benefits it has brought about. In particular, it is now clear that trends in transport activity volume and growth pose a real threat to sustainable development. The Vancouver International Conference 'Towards Sustainable Transportation' addressed this concern by exploring what might constitute a more sustainable transport svstem and charting a course towards that goal. This publication details the conference findings and offers a series of fundamental Sustainable Transportation Principles and Strategic Directions aimed at helping guide policy-makers. (97 97111 P) ISBN 92-64-15573-2. 176pp.

FF130 USS26 DM138 \$17 \$2,750

\section{Environmental Performance Reviews}

\section{Belarus}

\section{November 1997}

This study is part of the series of comprehensive Environmental Performance Reviews of the Economies in Transition which have been undertaken in the context of the work programme of the OECD's Centre for Co-operation with the Economies in Transition (CCET). It scrutinises efforts to meet both domestic objectives and international commitments. Evaluating progress in reducing the pollution burden, improving natural resource management, integrating environmental and economic policies, and strengthening international co-operation is also central to these reviews. The analyses presented are 
supported by a broad range of economic and environmental data.

Environmental performance reviews of Austria, Bulgaria, Canada, Finland, France, Germany, Iceland, Italy, Japan, Korea, the Netherlands, New Zealand Norway, Poland, Portugal, Spain, Sweden, the United Kingdom and the United States have already been published. (97 9718 1 P) ISBN 92-64-15626-7, 142 pp FF180 15S35 DM55 \$23 Y4.140

Financial, Fiscal and Enterprise Affairs

\section{Model Tax Convention on Income and on Capital Volumes I and II \\ December 1997 \\ (23 9750 I P) ISBN 92-64-15625-9, 1,160pp. \\ FF950 US5157 DM282 \$97 Y18.450}

\section{OECD Financial Statistics}

Part 1 Section 2

November 1997

(20 9711 3 P) ISBN 92-64-04711-5, 64pp., bilingual

\section{OECD Financial Statistics}

Part 1 Section 1

November 1997

(20 97213 P) ISBN 92-64-04721-2, 34pp., bilingual

Also available on diskette.

\section{OECD Financial Statistics}

Part 1 Section 1

November 1997

(20 97233 P) ISBN 92-64-04723-9. 18pp, bilingual

Also available on diskette.

1998 Subscription:

ISSN 030+-3371

FF2.215 USS 430 DM660 $\$ 260 \$ 47.500$

\section{Labour Market and Social lssues}

\section{OECD Proceedings}

\section{Labour Market Dynamics} in the Russian Federation November 1997

Five years into transition, the Russian labour market continues to adjust in response to far-reaching economic reforms. This publication shows how the nature and distribution of employment are changing and considers implications for economic performance and the well-being of individuals. It high- lights key flows and processes involved in the reallocation of labour resources in Russia and their impact on the labour market and households to date.

Not only does this publication analyse labour market movements and related developments in the Russian Federation, but it also quantifies them where possible, using newly available data sources. Accompanying in-depth analyses give valuable insights into the issue of labour dynamics in a transition economy. They even go so far as to challenge our assumptions,

(14 9712 I P) ISBN 92-64-15979-7, 161 pp FF90 LSS15 DM27 \$9 ₹1,750

\section{Science, Technology and Industry}

OECD Proceedings

\section{Industrial Competitiveness} in the Knowledge-based Economy

The New Role of Governments November 1997

Technological change and globalisation represent fundamental challenges for individuals, firms and policy-makers. Individuals are finding themselves confronted with increasing demands to develop and continuously upgrade their skills. Firms are radically changing the organisation of their operations within and across the boundaries of nation states. For governments, the room to manoeuvre is diminishing in national macro-economic and budgetary policies, while structural micro-economic policies - which affect the framework conditions that determine the competitiveness of firms - are assuming increasing importance. In the knowledgebased economy, such policies mus address a wide spectrum of issues such as intangible assets, knowledge infra. structures and flows, and intellectual property rights. At the same time there is a strongly perceived need for coherence between macro-economic and structural policy, as well as among the components of structural policy.

This publication brings together articles by a range of international experts and policy-makers. Their analyses and conclusions cover the wide spectrum of challenges facing governments in defining their new role in promoting industrial competitiveness and its contribution to job creation. (70 9703 I P) ISBN 92-64-15679-8, 256pp. FF160 [SS 32 DN477 \&21 $\$ 3.350$

Trade

\section{Employment Opportunities}

\section{Export Credit Financing Systems in OECD Member and non-Member Countries 1997 \\ Supplement \\ November 1997 \\ (229752 1 P) ISBN 92-64-15583-X, 145pp. \\ FF90 US\$18 DM26 \$12 Y1,900}

\section{OECD Proceedings}

Market Access Issues in the Automobile Sector

November 1997

See The OECD Observer, No. 209.

December 1997/January 1998.

(22 9701 I P) ISBN 92-64-15680-1,264pp.

FF160 15532 DM47 $521 \times 3,350$

\section{Transport}

\section{$\mathrm{CO}_{2}$ Emissions}

from Transport

November 1997

How are countries responding to the challenge of reducing $\mathrm{CO}_{2}$ emissions from transport? To find out, the European Conference of Ministers of Transport conducted an in-depth survey of its members around the world. This publication presents its findings. assessing what governments are actually doing to meet their commitments on climate change. The report goes on to focus on how the European automobile industry is responding to this issue and examines improvements in fuel consumption and $\mathrm{CO}_{2}$ emissions from new cars

The report concludes that measures taken so far will not stem transport sector emissions. Its findings provide an essential baseline for future intergovernmental negotiations on limiting greenhouse gas emissions.

(75 97061 P) ISBN 92-82-11225-X, 212pp. FF195 USS38 DN57 525 Y.100

\section{OECD Headquarters, Paris}

Vacancies occur in the OECD Secretariat in the following activities:

Public Administration

Balance of Payments

National Accounts

Agricultural Economics

Development Economics

Energy Economics

Industrial Economics

Labour Economics

Monetary Economics

Econometrics

Environment

Urban Studies

Fiscal Policy

Nuclear Engineering

Macro-Economics

Nuclear Physics

Education Policies

Social Affairs

Statistics

Computing and Communications

\section{Qualifications:}

relevant university degree; at least two or three years' professional experience; very good knowledge of one of the two official languages of the Organisation (English and French) and ability to draft well in that language; good knowledge of the other.

\section{Initial appointment:}

two or three years

Basic annual salary: from FF 318,000 (Administrator) and from FF 456,000 (Principal Administrator), supplemented by allowances depending on residence and family situation. Vacancies are open to candidates from $\mathrm{OECD}$ member countries. $\mathrm{OECD}$ is an equal opportunity employer and encourages applications from female candidates. Applications, in English or French (specifying area of specialisation and enclosing detailed curriculum vitae), should be marked 'OBS' and sent to:

Human Resources Management OECD 2, rue André-Pascal 755775 Paris Cedex 16 France 


\section{The OECD OBSERVER}

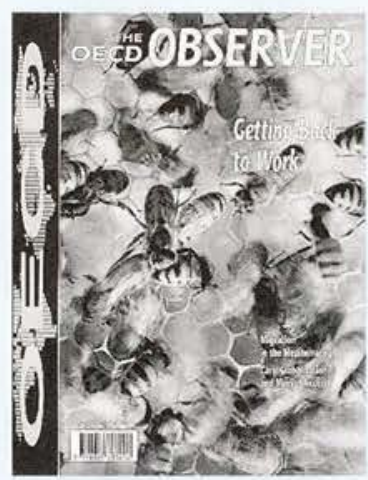

For concise, up-to-date and autboritative information on world economic and social problems, subscribe to The OECD OBSERVER.

Recent articles include: The Fight against Unemployment: Mobilising People Support • Lifelong Leaming and Employability - Opening Mediterranean Trade and Migration • Commerce Goes Electronic - Protecting Consumers in the Cybermarket - What Chance for the Virtual Taxman? • Involving Parents in Education - On the Thresbold of a Global Economy • A Consensus on Cryptograpby • Diffusing Technology to Industry • How Regulatory Change Affects the Economy • Can China Acbieve Self-sufficiency in Food? - The Growth of Network Computing

\section{OECD}

Economic Outlook

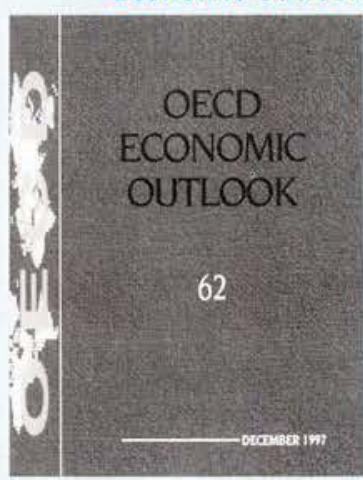

The Economics Department of the OECD puts forward its own consistent set of projections for output, employment, prices and current balances over the next two years, based on a review of each member country and of the induced effect on each of them of international developments. Particular attention is paid to the policies that governments are adopting to solve present economic problems. Summary statistics and projections are included for developments in non-member countries, in particular in central and eastern Europe as well as in selected Asian and Latin American countries.

OECD

\section{Economic Studies}

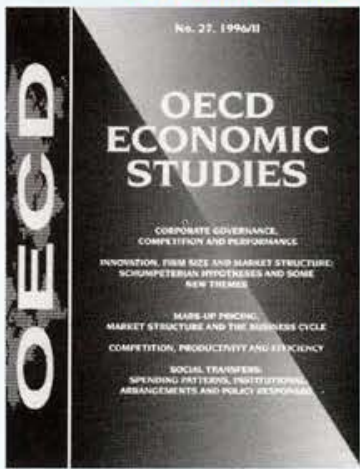

Contents No, 27:

- Corporate governance, competition and performance

- Innovation, firm size and market structure: Schumpeterian bypotheses and some new themes

- Mark-uppricing, market structure and the business cycle

- Competition, productivity and efficiency

- Socialtransfers: spending patterns, institutional arrangements and policy responses
Return this order form in a stamped envelope

- to OECD Publications in Paris

- to the OECD Publications Distributor in your country, or

- to the OECD Centre in Bonn, Mexico, Tokyo or Washington

Addresses on p. 62

Return this order form in a stamped envelope

- to OECD Publications in Paris

- to the OECD Publications Distributor in your country, or

- to the OECD Centre in Bonn, Mexico, Tokyo or Washington

Addresses on p. 62
Return this order form in a stamped envelope

- to OECD Publications in Paris

- to the OECD Publications Distributor in your country, or

- to the OECD Centre in Bonn, Mexico, Tokyo or Washington

Addresses on p. 62

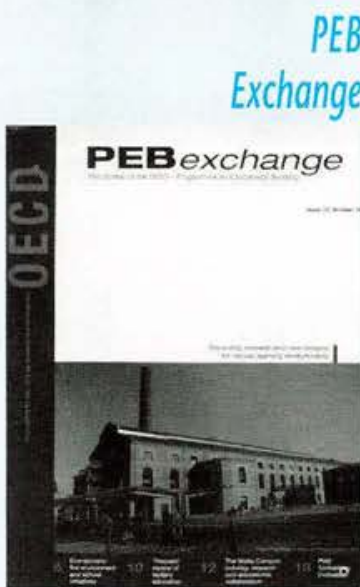

The OECD Programme on Educational Building (PEB) promotes the exchange of ideas, information, research and experience in the field of educational facilities. Its participants include national governments, state and provincial government and research organisations. Its main themes are: improving the quality of educational buildings; management of the physical resources for education; change and its impact on educational facilities. PEB Exchange gives an international perspective from educators, administrators and architects on educational facility issues in OECD countries, and addresses all issues in a cost-effective way.
Return this order form in a stamped envelope

- to OECD Publications in Paris

- to the OECD Publications Distributor in your country, or

- to the OECD Centre in Bonn, Mexico, Tokyo or Washington 
Subscription

FF150 US\$30 DM46 $£ 17 ¥ 3,200$

Supplement for rapid airmail: consult the OECD

For Visa credit-card payment, please indicate: Card No.

Expiry Date

Date

Signature

1998 Subscription

FF310 US\$60 DM90 £36 $¥ 6,600$

Supplement for rapid airmail: consult the OECD

For Visa credit-card payment, please indicate: Card No.

Expiry Date

Date

Signature

1998 Subscription

FF305 US\$65 DM93 $£ 36 ¥ 6,500$

Supplement for rapid airmail: consult the OECD

For Visa credit-card payment, please indicate: Card No.

Date

Signature

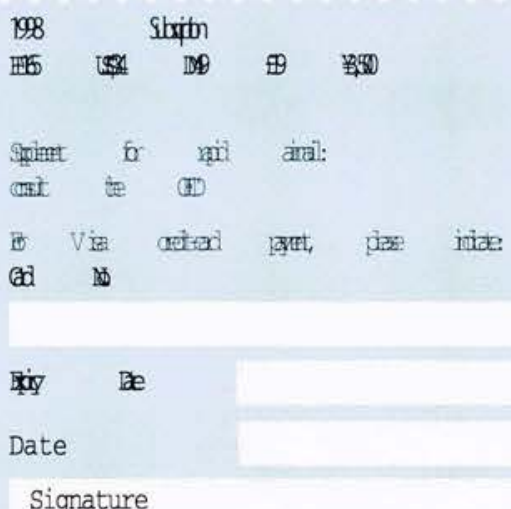

\section{OECDE OBSERVER}

$\square$ ENGLISH $\quad \square$ FRENCH
SURNAME (in capitals)/FIRST NAME

6 issues per year

\section{PROFESSION}

ADDRESS $\square$ HOME $\square$ BUSINESS

POSTCODE-TOWN/CITY

COUNTRY

\section{OECD Economic OutLook}

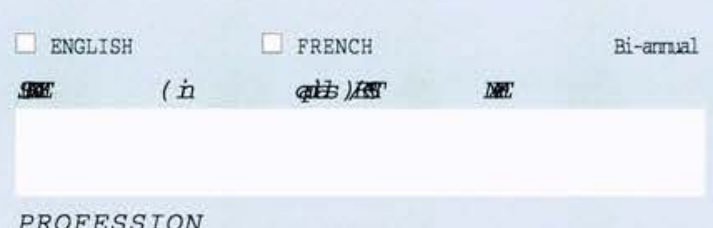

AD DRESS $\square$ HOME $\square$ BUSINESS

POSTCODE-TOWN/CITY

COUNTRY

\section{- Economic Studies}

$\square$ ENGLISH $\square$ FRENCH
SURNAME (in capitals)/FIRST NAME

\section{PROFESSION}

ADDRESS $\square$ HOME $\square$ BUSINESS

POSTCODE-TOWN/CITY

COUNTRY

\section{PEB EXCHANCE}

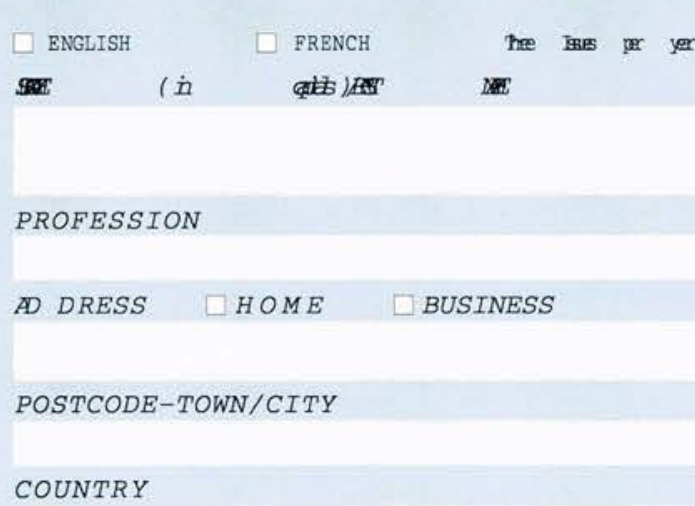

Bi-annual

\section{Other OECD Publications}

\begin{tabular}{l}
$\square$ ENGLISH FRENCH \\
\begin{tabular}{|l|l|}
\hline Title & OECD Code* \\
\hline & \\
\hline & \\
\hline & \\
\hline & \\
\hline & \\
\hline & \\
\hline
\end{tabular} \\
\hline
\end{tabular}

For publications mentioned in articles in THE OECD OBSERVER, please contact be OECD Publications Service forprices.

\section{Other OECD Publications}

\begin{tabular}{|l|l|}
\hline INGISH & $\square$ FRENH \\
\hline Title & OECD COde* \\
\hline & \\
\hline & \\
\hline & \\
\hline & \\
\hline & \\
\hline
\end{tabular}

\section{Other OECD Publications}

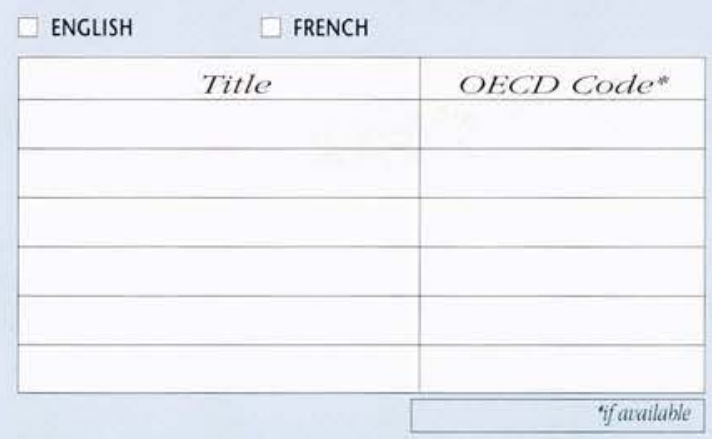

\section{Other OECD Publications}

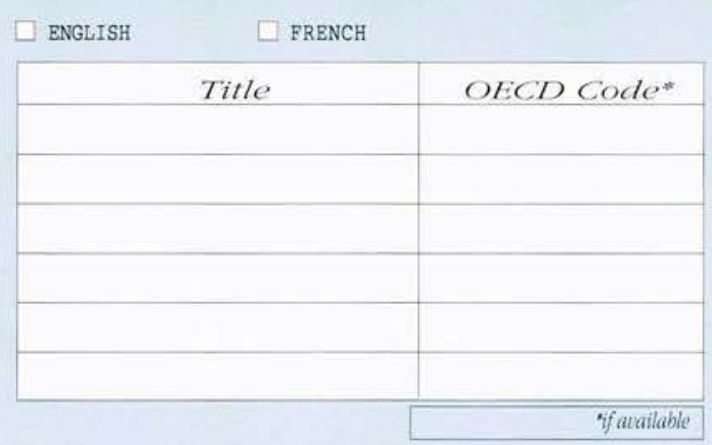




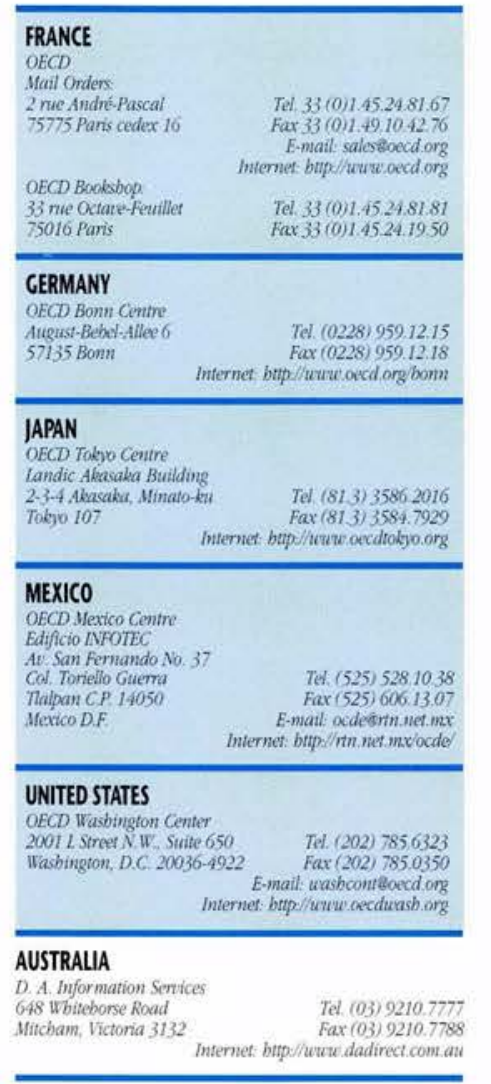

\section{AUSTRIA}

$\begin{array}{lr}\text { Gerold E Company } & \text { Tel } 102222533.50 .14 \\ \text { Graben 31 } & \text { Fax }(0222) 512.473129\end{array}$

\section{BELCIUM}

ateme du Roi Koningslaan, $202 \quad$ Tel. (02) 53851.69 1190 Brusels Fax (02) 53808,41 internet bttp//urw jean-de-tamov bo

Jean De Lamnoy
Rue des Cheraliersiddenstraat, it

1050 Brissels

\section{CANADA}

Remouf Publishing Gompunitu

Tel. (613) 745.2665 Mtawa, ONT KIJ 9].

Internet bitp-/fox ustil cat remout

$71 \% 2$ Spanks Street

Ottaua ONT KIP $5 R I$

Toromo. ONT MSH $3 B$ B

Les Editions De La Libené Inc.

3020 Cbemin Sainte-Foy
Sainte-Foy, PQ G1X $316 \%$

Tel (613) 238.8985 Fax (613) 2386041 Fax $(416) 3635963$

Federai Publications inc.

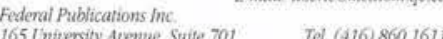
Toronto, ONT MFH 3BS Intemet butpi/nuw fedpubs.com/jedpubs Les Publications Fédênales
1185 Unitersité $\begin{array}{lr}1185 \text { Unitersite } & \text { Tel. (514) } 954.1633 \\ \text { Montrail, QCHBB 3A7 } & \text { Fax }(510954.1635\end{array}$

\section{CHINA}

Coma National Pubications

Serials Deparment

16 Gongti E. Road, Chaoyang District

Bejing 100020 Tel. (10) 6506.6688 Ext 8402

Suindon Book Co. Ld

Astoria Bldg. $3 F$

Tel. 23762062

Kowloen, Hong Kong $\quad$ Fax 2376.0685

\section{CHINESE TAIPE}

CHINESE TALPE

9tb Fhoor No. $118, \mathrm{Sec} 2$

$\begin{array}{lr}\begin{array}{l}\text { Chung Hsiao E Road } \\ \text { Taipet }\end{array} & \text { Tel }(02) 391.73967397 \\ \text { Fax (02) } 3949176\end{array}$

\section{CZECH REPUBLIC}

National inforn
Konvibusteâ 5

Praba $1-11357$

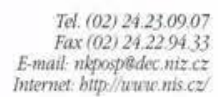

\section{DENMARK}

DENMARK

35, Nenre Sogade, PO, Bax 2148 Tel (33) 12.85.70

1016 Kobenbatn

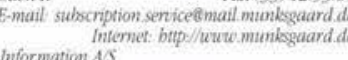

H. Scbultz Information AS

Hersiediang 12 E-mails-infoeinetrami-c.de

EGYPT

The Mriddle East Obsenu

41 Sberif Strev

Teiffax (2) 393.9732

Cairo E-mail: foudazsoficom com eg

\section{FINLAND}

Akateeminen Kinakanppoz

Tel. $(358) 91214118$

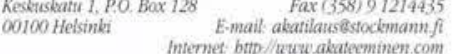

\section{FRANCE}

See bax:

$B P 40$

92121 Palaisean cedex

Documentation françalse

29. quai Voftaire

75007 Paris

Giber Jeune (Droit-Économie)

6. place Saint-Siched

75006 Paris

Libraine du commerce international

10, avenue dTéna

75016 Paris

tinitersité Paris-Dauphine

Place du Marichal-de-Lattre-de-Tassigmy

75016 Paris

Libraine Latoisie

75008 Paris

Libminie des sciences politipues

30. nue Saint-Grillatme

75007 Paris

PUT

49. boulezand Saint-Michel

75005 Pars

Libraine de II niversite

12. nue Nazaretb

13100 Aix-en-Protence
Docimentation framcaise

Docrumentation frangctise
765 , nie Garibaldi

69003 Lyon

29. place Bellecotar

60002 Ljey

Librainie Sauramps

Le Triangh

Le Thangle
34967 Montpellier cedex 2

A la Soriomne Actual

23. nue de I Hôtel des Posté

\section{KOR}

\section{GREECE}

Lbonaine Kaufmann

Stadiou 28
10564 then

TeL/Fax (OD) 32,30320

HUNGARY

Euro Info Senvice

Margitsziget, Európa Häz

$\operatorname{Fax}(1) 302.5035$

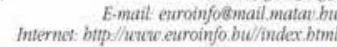

\section{ICELAND}

Măl og Menning

Laugategi 18, Postbolf 392

121 Reysjari

INDIA

Oxford Book and Stationery Co. Tel, (I1) $331,5896,5308$

Scindia House
Fax (11) 3322639

New Delht $110001 \quad$ E-mail axford.editoreacess.net in

INDONESIA

Pdi-Lipt
PO Box 4200

Jakarta 12042

Tel/Fax (21) 57334.67

\section{IRELAND}

Government Supplies Agency Publications

45 Harcout Roat
Dublin 2

ISRAEL

Praedicta

5 Shatner Street

PO. Box 34030

Via Duca di Catahria ba

P. Bax 12418 Fax (33) 12.93 .87

Tel (43) 63.23 .00
Far (43) 6319.60

Kyobo Book Centre Co. Lta

P.O. Bax 1658, Kuang Hwa Moon

Tel. $01.69 \cdot 10.47 .00$

Fax 01.64 54.83.26

Tet. 01.40 .15 .70 .00

Tel. 01.432591 .19

Tel. 01.40 .733460

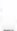

Tel. 01.44.05.40.13

Te1. 01.42 .65 .3995

Tel. 01.45 .483602

Tel. 01.444181 .20

Tel. 04.42 .26 .1808

Tel. 04.78 .6323 .02

Tel. 04.72.40.54.54

Tet. 04.6706 .78 .78

axt 040313.7275

Fax 01.93 .8075 .69

7el (1) 111.60 .61

Tel. (1) 552.4240

Fax (1) 562352

Tel. (33) 240832

Tel 661.31 .11
Fax 475.27 .60

RO.Y. International

Tel Arit 61130

Palestinian Autborit

POB. 1950

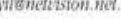

ITALY

Lhreria Commiscionaria Sans

50125 Firenze

Via Bartolini 29

Editrice e Libreria Herder

Piazza Montectlono 120

OOIS6 Roma

via Hoepti 5

20121 Milano

Labreria Scientifica

Doth Lacto de Ras

2146 Milano

$\operatorname{Fax}(2) 6271219$

Se

MALAYSIA

Chitersity of Malaya Boolshop
PO. Box 1127 . Jalan Pantai Ban

59700 Kuala Lumpu

(n)

Tel. $756.5000 / 542$

Fax 756,324

\section{NETHERLANDS}

Posthis 20014

2500 EA S-Gravenbage

(Sales Subscriptions)

De Lindetroom Internationale Publikut

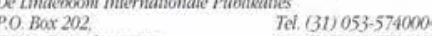

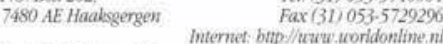

Surets 6 Zeitlinger $B V$

$\begin{array}{ll}\text { Heereteg } 3478 \text { P. Box } 830 & \text { Te. } 252.435111 \\ \text { 2160 SZ Lisse } & \text { Fax 252.415.888 }\end{array}$

\section{NEW ZEALAND}

Tel. (04) 496.5653

Fax (04) 496.5608

政

PO. Box 3627

Tel. $(04) 4991148$

Fax (04) 4991972
E-mail: odsis\$actrixgen:nz

\section{NORWAY}

NCINFOAS

Dotensiverien 18

Tel. (22) 97.45 .00

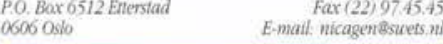

\section{PAKISTAN}

Mirza Book Agenc

55 Sbabrab Quadd-E-Azan

E-mait. nicagen 뼌ets, nt

Labore 54000

Tel (42) 723.1730
Fax (42) 576.37 .14

\section{PHILIPPINES}

International Boole Store In

3F, Rudgen II Building

Tet. (63.2) 633.6136

Metro, Manila Fax (63.2) 631.3766

\section{POLAND}

rakouskie Prezdmiescte Fax (22) 26.5334
E-mail: arspolebety.bsn.compl

Tel (22) 26.12.01

\section{PORTUGAL}

Litraria Portugal

$\begin{array}{lc}\text { Apart } 2681 & \text { Tel. }(01) 347.49 .82 / 5 \\ 1200 \text { lisboa } & \text { Fax (O1) } 347.02 .64\end{array}$

1200 lisione

\section{SINGAPORE}

tsia Pacific Pre. Lid

Golden whed Building, 05-03

11. Kallang Pudding Road

singapore 349316

\section{SLOVENIA}

Gospodarsk Vestrik Publishing Group Tel. (61) 133.03 .54

repanseljiggrestmiksi

\section{SPAIN}

Mundi Prensa Libros S.A

Castello 37 . Apartado 122

Madrid 2800 ?

Mundi Prensa Barcelona

Tel (93) 4883492
Fax $(93) 487.76 .59$ L-mail barcelonatmundiprensa. Rambla dels Estudis, 118 (Subscriptions) Tel. (93) 318.801 a8002-Barcelona (Publications) Tol (93) 302.67.2

SWEDEN

Akademihabbandely

0425 stoclibion

Tel. (08) 7282500 Fax $(08), 3130$.

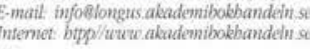

Subscription Agency:
Tremienren-Williams Info $A B$

PO. Box 1305

17125 Sobna

For electromic publications only.

Statistics Sueden

Informationssentice 


\section{The \\ 10 \\ best \\ sellers \\ of the \\ past \\ 2 \\ months}
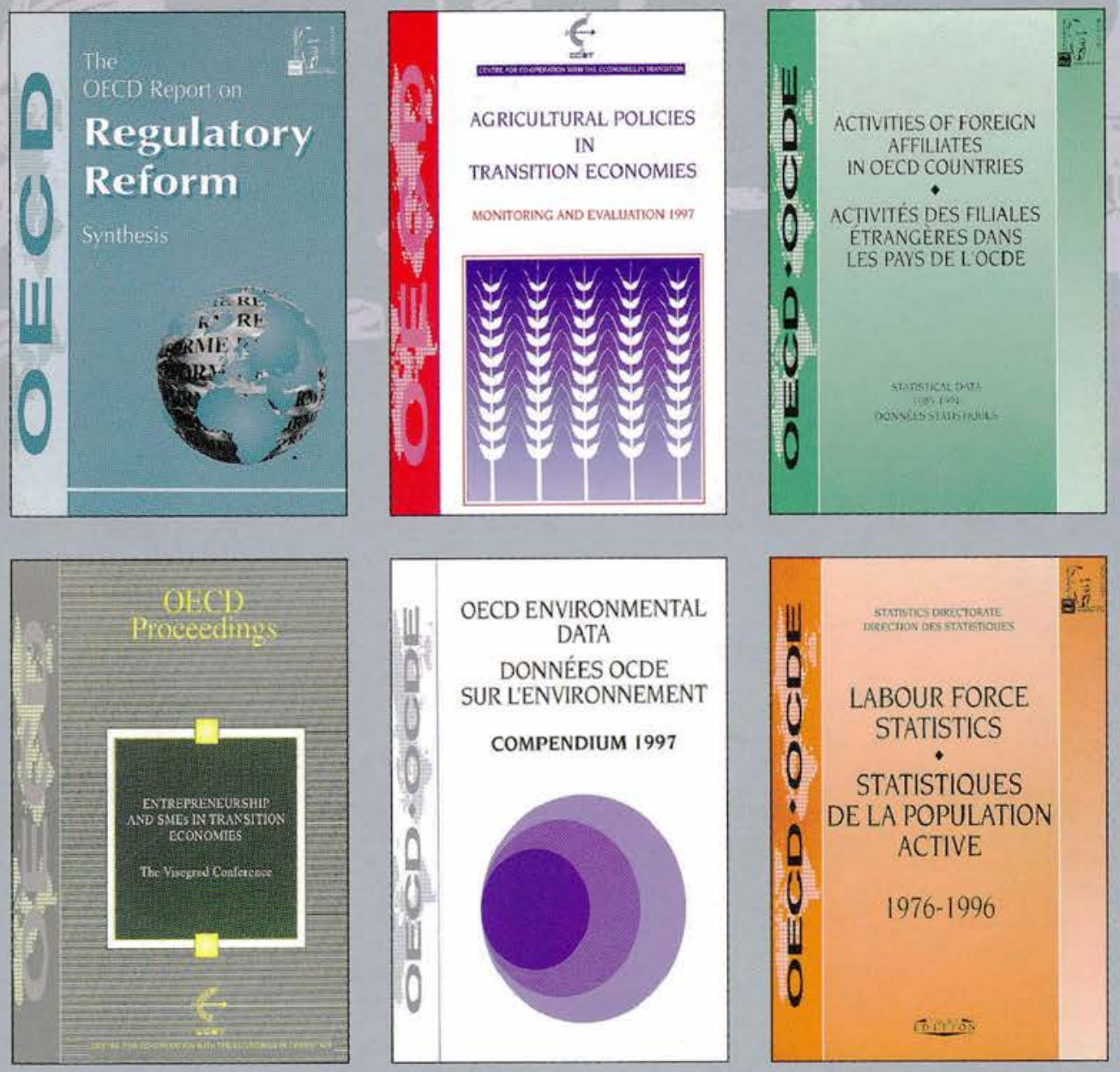

\section{OECD \\ Publications}
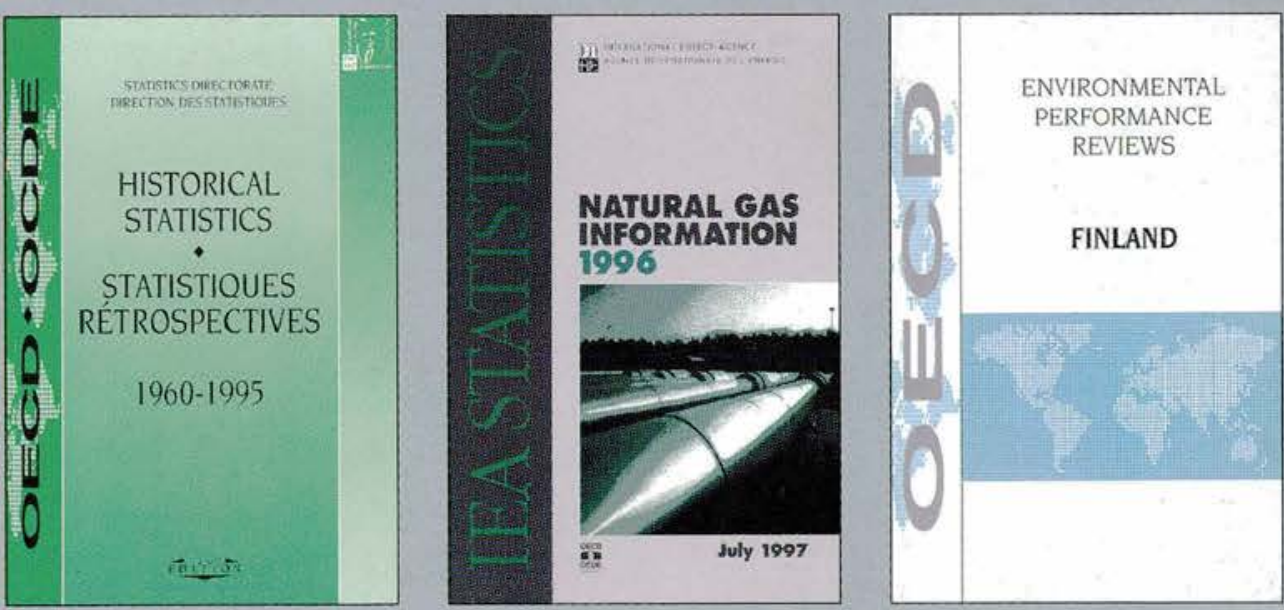